\title{
ANÁLISE ESPACIAL DA OCORRÊNCIA DO ÍNDICE DE CONE EM SISTEMAS DE SEMEADURA DIRETA E SUA RELAÇÃO COM FATORES RELACIONADOS À FÍSICA DO SOLO
}

\section{RAPHAEL PINHEIRO DE MAGALHÃES}

Dissertação apresentada à escola superior

de agricultura "Luiz de Queiroz", Universidade de São Paulo, para obtenção do título de Mestre em agronomia, Área de concentração: Máquinas Agrícolas

PIRACICABA

Estado de São Paulo - Brasil

Julho - 2005 


\title{
ANÁLISE ESPACIAL DA OCORRÊNCIA DO ÍNDICE DE CONE EM SISTEMAS DE SEMEADURA DIRETA E SUA RELAÇÃO COM FATORES RELACIONADOS À FÍSICA DO SOLO
}

\section{RAPHAEL PINHEIRO DE MAGALHÃES}

Engenheiro Agrônomo

Orientador: Prof. Dr. JOSÉ PAULO MOLIN

\author{
Dissertação apresentada à escola superior \\ de agricultura "Luiz de Queiroz", \\ Universidade de São Paulo, para obtenção \\ do título de Mestre em agronomia, Área de \\ concentração: Máquinas Agrícolas \\ PIRACICABA \\ Estado de São Paulo - Brasil \\ Julho - 2005
}


Dados Internacionais de Catalogação na Publicação (CIP) DIVISÃO DE BIBLIOTECA E DOCUMENTAÇÃO - ESALQ/USP

Magalhães, Raphael Pinheiro de

Análise espacial da ocorrência do índice de cone em sistemas de semeadura direta e sua relação com fatores relacionados à física do solo / Raphael Pinheiro de Magalhães. - - Piracicaba, 2005.

$69 \mathrm{p}$.

Dissertação (Mestrado) - - Escola Superior de Agricultura Luiz de Queiroz, 2005. Bibliografia.

1. Agricultura de precisão 2. Água do solo 3. Análise espacial 4. Compactação do solo 5. Física do solo 6. Plantio direto I. Título

CDD 631.43

"Permitida a cópia total ou parcial deste documento, desde que citada a fonte - O autor" 


\section{AGRADECIMENTOS}

Ao meu orientador e aos colegas de departamento pelo auxílio e amizade.

Aos funcionários do departamento, pela dedicação e competência.

A minha família pela paciência e carinho.

A CAPES pela concessão da bolsa.

Ao CNPQ pelo financiamento do projeto.

Aos funcionários da fundação $\mathrm{ABC}$ e proprietários das fazendas Sol e Irmãos Borges, que possibilitaram a execução da investigação científica no campo. 


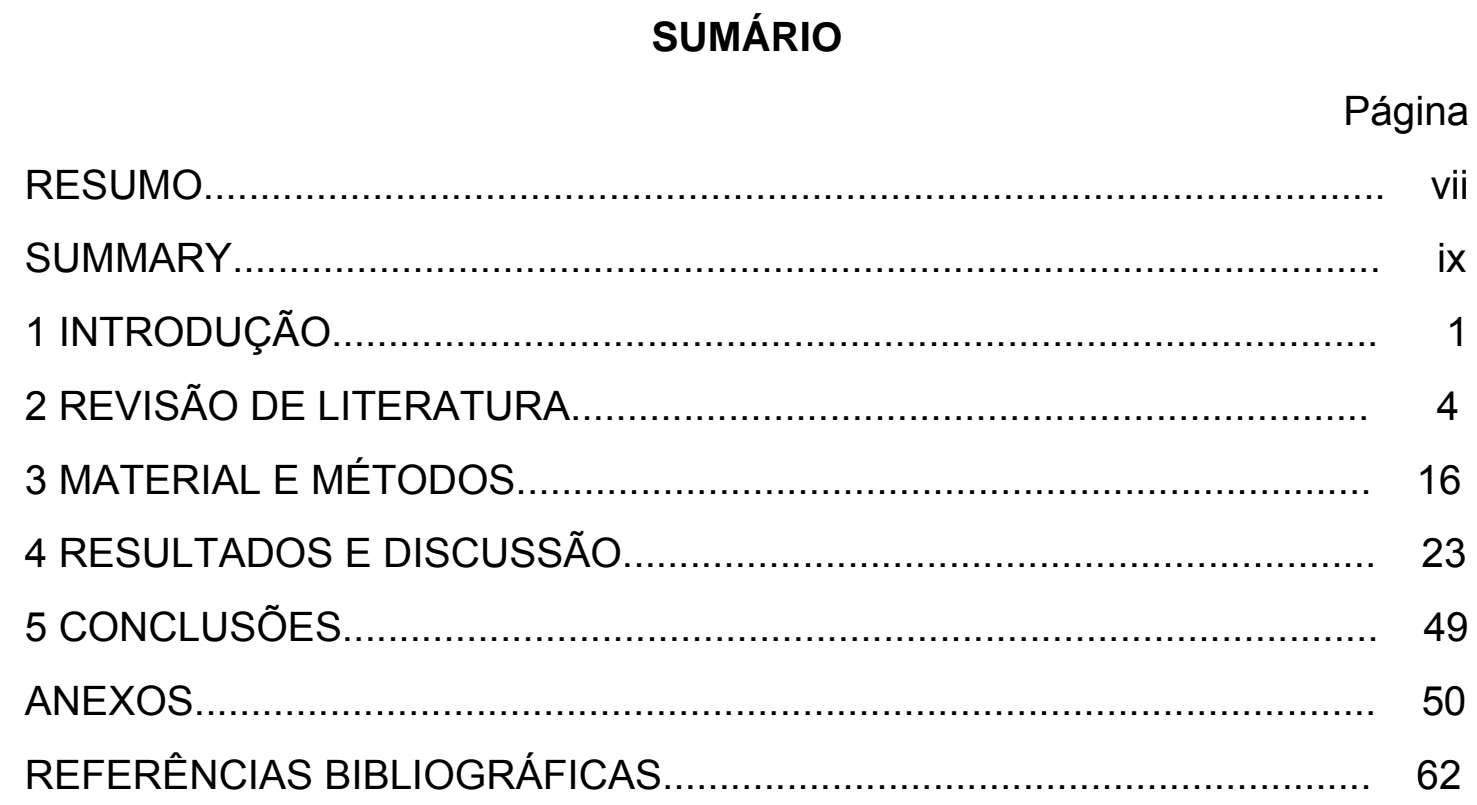




\section{LISTA DE FIGURAS}

Página

1 llustração do penetrômetro com detalhe para as partes mais importantes 19

2 Mapas dos atributos IC e teor de água do solo, estudados na área 1, por faixas de profundidade $(\mathrm{m})$

3 Mapas dos atributos IC, teor de água e teor de argila do solo, estudados na área 2, por faixas de profundidade $(\mathrm{m})$

4 Mapas dos atributos IC, teor de água, teor de matéria orgânica, teor de argila, densidade e espaço poroso do solo, estudados na área 3 


\section{LISTA DE TABELAS}

Página

1 Parâmetros da estatística descritiva referentes ao IC e teor de água para a área 1.

2 Parâmetros do semivariograma para IC e umidade referentes à área 1.. 25

3 Índice de correlação entre os dados interpolados dos parâmetros estudados na área 1

4 Parâmetros da estatística descritiva referentes ao IC, teor de água e teor de argila para a área 2

5 Parâmetros relativos ao ajuste do semivariograma para IC, teor de água e teor de argila referentes à área 2 .

6 Regressão entre os dados interpolados dos parâmetros estudados na área 2

7 Parâmetros da estatística descritiva referentes ao IC, teor de água, teor de matéria orgânica, teor de argila, densidade e espaço poroso do solo para a área 3.

8 Parâmetros relativos ao ajuste do semivariograma para o IC, teor de água densidade e espaço poroso do solo para a área 3.

9 Regressão entre os dados interpolados dos parâmetros estudados na área 3 


\title{
ANÁLISE ESPACIAL DA OCORRÊNCIA DO ÍNDICE DE CONE EM SISTEMAS DE SEMEADURA DIRETA E SUA RELAÇÃO COM FATORES RELACIONADOS À FÍSICA DO SOLO
}

\author{
Autor: RAPHAEL PINHEIRO DE MAGALHÃES \\ Orientador: Prof. Dr. JOSÉ PAULO MOLIN
}

\section{RESUMO}

O presente estudo objetivou a análise, em lavouras sob semeadura direta, da distribuição vertical e horizontal da resistência à penetração medida por valores georreferênciados do Índice de Cone (IC) e a influência do teor de água do solo, permitindo assim a interpolação para análise de relações causa e efeito. Fatores importantes como o teor de argila, silte, densidade, espaço poroso e teor de matéria orgânica do solo também foram monitorados. Utilizou-se um penetrômetro hidráulico eletrônico, receptores de GPS, amostradores de solo e programas computacionais para o tratamento e obtenção dos resultados em três áreas de estudo sob semeadura direta. Os resultados foram apresentados na forma de mapas em diferentes profundidades, os quais permitem a visualização da espacialidade dos atributos, e pela regressão entre os dados interpolados através da função que apresentou o coeficiente de determinação $\left(R^{2}\right)$ mais elevado. Constatou-se a ocorrência de valores maiores para o IC nas profundidades compreendidas de 
0,1 a 0,2 $\mathrm{m}$ em todas as áreas estudadas. Observou-se também valores menores de IC em locais com maior teor de matéria orgânica, a qual coincidiu com maiores teores de argila e silte em uma das áreas para a qual estes três atributos foram monitorados. A visualização das relações entre fatores nos mapas e a regressão adequada entre os valores interpolados dos atributos destes nem sempre foram possíveis, mas quando houve esta possibilidade, a inter-relação entre o IC e o teor de água, assim como todas as relações espaciais com os demais atributos do solo estudados foram visíveis nos mapas e constatáveis pelo modelo ajustado. O IC foi influenciado principalmente pelo teor de água, densidade e espaço poroso do solo. No entanto seu valor também variou em decorrência de outras inter-relações existentes, as quais estão relacionadas aos teores de argila, silte e matéria orgânica. 


\title{
SPATIAL ANALYSIS OF CONE INDEX PRESENCE IN DIRECT SEEDING SYSTEMS AND ITS RELATIONSHIP WITH SOIL PHYSICAL ATTRIBUTES
}

\author{
Author: RAPHAEL PINHEIRO DE MAGALHÃES
}

Adviser: Prof. Dr. JOSÉ PAULO MOLIN

\section{SUMMARY}

The objective of this study is to measure the vertical and horizontal distribution of cone index $(\mathrm{Cl})$ values in no- till systems and the influence of soil water content. Data were interpolated allowing for cause and effect analysis. Other important factors as clay and silte content, bulk density, porous space and organic matter content had been monitored. A hydraulically penetrometer was used together with GPS receiver, soil auger and computer programs to collect and analize the data in tree different areas. Results allowed for the generation of maps of the attributes on different depts, and the regression among the interpolated data, choosing the models with the higher determination coefficient $\left(R^{2}\right)$. It was evidenced, in all areas, high $\mathrm{Cl}$ values at depth betwen 0,1 to $0,2 \mathrm{~m}$. Lower values of $\mathrm{Cl}$ occurred, in one of the areas, in the same place of higher organic matter, in the same located of higher clay and silt content. The visualization of relationship between two factors in the maps and the regression among the interpolated values extracted from those maps was not always possible, but when that possibility took place, the relationship between the $\mathrm{Cl}$ 
and water content, as the other spatial relations, was visible in the maps and achievable by the modeling of the data extracted from them. The $\mathrm{Cl}$ was first influenced by the water content, bulk density and porous space. Nevertheless it also varied as function of clay, silte and organic matter content. 


\section{INTRODUÇÃO}

A agricultura de precisão assume a desuniformidade espacial existente nas lavouras, oferecendo estratégias e conceitos úteis tanto para o gerenciamento desta desuniformidade quanto para a pesquisa dos fenômenos envolvidos com a variabilidade.

A semeadura direta, mais conhecida como plantio direto, trata do cultivo dos solos eliminando seu preparo periódico e conservando os restos culturais das culturas anteriores nos cultivos subseqüentes. Quando comparado à semeadura convencional, que tende a diminuir o teor de matéria orgânica dos solos, influenciar nas suas agregações e provocar o aumento das suas temperaturas, a semeadura direta, em locais de clima tropical, tem se mostrado mais apropriada, conservando alguns atributos físicos dos solos, melhorando suas características e conseqüentemente provocando 0 aumento da produtividade das culturas. No entanto, em alguns casos, este sistema tem potencializado a compactação superficial do solo devido à pressão exercida pelo maquinário utilizado e pela ausência de revolvimento superficial através do preparo periódico.

Entende-se por compactação o processo de estresse mecânico, caracterizado pelo decréscimo em volume e aumento da densidade através da deformação do solo, o que causa a extrusão, preferencialmente do ar dos poros. O aumento da sua densidade normalmente provoca uma elevação da resistência à penetração das raízes, submetendo a cultura a uma situação de estresse, a qual muitas vezes resulta na diminuição da produtividade.

Em algumas situações tal aumento de densidade é decorrente do adensamento do solo pela decomposição da sua matéria orgânica. Esta 
situação de adensamento não se aplica ao sistema de semeadura direta, uma vez que o mesmo não promove a perda da matéria orgânica dos solos (Triplett Junior \& Van Doren Junior, 1969).

A compactação dos solos também pode provocar o decréscimo dos seus espaços porosos através da diminuição dos macroporos pela deformação da sua estrutura, o que muitas vezes resulta no aumento dos seus microporos. A diminuição deste espaço poroso proporciona menor disponibilidade de oxigênio às raízes das culturas e microorganismos presentes na estrutura do solo, o que pode contribuir para a degradação de sua qualidade no suporte da vegetação, potencializando assim o decréscimo da produtividade e muitas vezes, a morte de plantas cultivadas.

A magnitude da compactação tem sido mensurada por meio de equipamentos denominados penetrômetros, os quais identificam a resistência oferecida pelos solos para a penetração de uma sonda na forma de cone. Esses equipamentos quantificam a pressão de penetração resultando em valores denominados de índice de cone (IC), que por sua vez se relacionam diretamente com a densidade dos solos e inversamente com a umidade (Aase at al., 2001; Imhoff et al., 2000). Apesar de existirem outros parâmetros físicos dos solos que influenciam na variação do IC, como por exemplo os teores de argila e silte e a pedologia dos mesmos, o teor de água, em conjunto com o fator densidade, são apontados como os principais atributos de influência neste índice (Vasques et al., 1991). Como os penetrômetros foram desenvolvidos para mensurar a resistência à penetração como medida indireta dos efeitos de compactação nos solos, a influência da umidade no IC é indesejada, o que tem motivado estudos para a verificação da importância dessa influência ou tentativas de isolar esse fator.

Este trabalho propõe a investigação, em sistemas de semeadura direta, da ocorrência e distribuição vertical e horizontal da compactação bem como a influência do teor de água do solo na sua resistência à penetração medida através do IC, de forma espacilizada, com dados amostrados e 
georreferenciados que permitem interpolação para análise de relações causa e efeito. Outros fatores considerados importantes também foram monitorados e analisados, como o teor de argila, teor de silte, densidade, espaço poroso e teor de matéria orgânica do solo. 


\section{REVISÃO DE LITERATURA}

A exploração dos solos para a produção de alimentos potencializa a sua degradação de diversas formas, sendo a compactação uma delas. Gupta \& Allmaras (1987) descrevem a compactação como a compressão em estado não saturado do solo, caracterizada pelo decréscimo em volume e aumento da densidade, preferencialmente através da extrusão do ar dos seus poros. Seixas (1988) descreveu esta compactação por mudanças resultantes em termos de aumento da densidade, decréscimo no volume de macroporos, infiltração e movimento interno de água mais lentos e maior resistência mecânica ao crescimento das raízes.

Esse processo pode ser causado por máquinas e implementos agrícolas, como constatado por Novak et al. (1992) em estudo sobre o efeito do tráfego de trator e pressão de contato do pneu sobre um latossolo. Silva (2002) atribui a compactação dos solos à associação do tráfego de máquinas com condições de umidade inadequadas, não respeitando a sua capacidade de suporte de cargas.

Segundo Mielnickuk (1993), a compressão exercida por máquinas agrícolas é uma das ações que podem conferir ao solo estrutura maciça, com redução de seu espaço poroso, aumentando sua densidade e resistência à deformação. $O$ autor cita como outras causas dessa alteração, práticas que promovem o fracionamento de agregados ou redução via atividade microbiana de compostos orgânicos responsáveis pela sua estabilidade.

Do ponto de vista agrícola, a perda de matéria orgânica dos solos proporciona que se tornem uma fonte de $\mathrm{CO}_{2}$ para a atmosfera, caso as perdas por oxidação do carbono de origem orgânica sejam maiores do que as adições. 
Os sistemas de manejo que utilizam o preparo do solo para a produção vegetal constituem-se no principal fator dessas perdas (Bruce et al., 1999), uma vez que este preparo provoca a ruptura dos agregados e exposição da matéria orgânica, a qual está atuando como agente de ligação entre microagregados ao ataque da biomassa microbiana. A diminuição da matéria orgânica causa o adensamento do solo, influenciando por isso, de maneira diretamente proporcional, no aumento da sua resistência à penetração.

O preparo do solo também provoca a mistura do material orgânico com a sua fração mineral, resultando em condições mais favoráveis à decomposição desse material, e promovendo o aumento na atividade de biomassa microbiana devido à maior aeração e ao aumento da oferta de fonte de carbono facilmente oxidável, o que resulta em maior fluxo de mineralização do carbono (Elliot, 1986; Powlson et al., 1987; Reicosky et al., 1995).

Contudo, o solo não será adensado quando, por outro lado, tornar-se um dreno de $\mathrm{CO}_{2}$ atmosférico, ou seja, quando houver incremento de matéria orgânica decorrente de maiores adições do que perdas por oxidação de carbono. Segundo Bruce et al. (1999), as medidas necessárias para promoção do incremento de matéria orgânica estão relacionadas à redução e/ou eliminação da intensidade de preparo do solo, intensificação de sistemas de rotação de culturas e restabelecimento de cobertura vegetal permanente. A primeira dessas medidas ocorre na prática de semeadura direta, indicando um potencial desse sistema em causar o aumento da matéria orgânica do solo, o qual inclusive já foi constatado em experimentos de longa duração (Triplett Junior \& Van Doren Junior, 1969).

Da mesma forma que a destruição do teor de matéria orgânica dos solos submetidos a modelos de gestão inadaptados pode acontecer rapidamente, sua recuperação pode andar na mesma velocidade em semeadura direta, uma vez que nesse sistema de cultivo os níveis de teor de matéria orgânica podem alcançar e até ultrapassar os dos ecossistemas naturais (L. Séguy \& Bouzinac, 2001). 
A semeadura direta, também conhecida como plantio direto, caracterizase como uma técnica conservacionista do solo que dispensa o seu preparo periódico. Sua prática foi iniciada através de trabalhos de americanos e ingleses por ocasião do surgimento do primeiro herbicida de contato, e ganhou impulso com melhores alternativas de semeadoras e principalmente, pela descoberta dos herbicidas sistêmicos (não-seletivos e seletivos), os quais garantiam maior eficiência no controle de plantas invasoras (Saturnino \& Landers, 1997).

A essência do sistema de semeadura direta é manter a palha recobrindo o solo, e mesmo a semeadura direta visando perturbar o mínimo possível a estrutura física e a vida biológica do solo (Saturnino \& Landers, 1997), observase os efeitos da compactação através do aumento da sua densidade superficial, tendo como conseqüência maior resistência à penetração ou IC, detectada em cultivos sob semeadura direta por autores como Santos (1993) de 0,000 a 0,050m, Klein (1998) de 0,000 a 0,400m, Bertol. et al. (2001) de 0,000 a 0,025 m, Silva Junior (2001) de 0,100 a 0,200. Da mesma forma, Abrão et al. (1978), ao comparar alguns métodos de preparo de solo, concluíram que aqueles com menor mobilização apresentaram melhor agregação e maior resistência à penetração.

Por outro lado Ramos (1976), na região centro sul do Paraná, Mondardo (1978) no Norte do Paraná e Wunshe \& Denardin (1978) no planalto do Rio Grande do Sul, enfatizaram a eficiência da semeadura direta no controle das perdas por erosão.

O sistema de manejo do solo pode influenciar na sua quantidade de matéria orgância, a qual é indiretamente referenciada pelo seu teor de carbono. Duxbury et al. (1989), alocando diferentes estágios da dinâmica do carbono em quatro compartimentos ("pools"), os representa como: compartimento ativo ou lábil, compartimento lentamente oxidável, compartimento muito lentamente oxidável e compartimento passivo ou recalcitrante. O compartimento ativo ou lábil é constituído por compostos orgânicos facilmente oxidáveis derivados de fragmentos vegetais recentes, controlado pela adição de resíduos culturais, 
fortemente influenciado pelo clima e tipo de manejo. As modificações deste são rápidas e elevadas quantidade de $\mathrm{C}$ e $\mathrm{N}$ estão em função das transformações da biomassa microbiana. O compartimento lentamente oxidável está relacionado com macroagregados e é controlado pela mineralogia e fatores agronômicos que interferem na agregação. Dentre estes os sistemas de manejo do solo afetam o tamanho desse reservatório. O compartimento muito lentamente oxidável relaciona-se com os microagregados e o fator controlador é a sua estabilidade em água, sendo influenciado pouco pelo sistema de manejo do solo. Por último, o compartimento passivo ou recalcitrante está relacionado com o carbono associado às partículas primárias do solo, sendo controlado pela mineralogia da fração argila através da formação de complexos organo-argílicos pela decomposição microbial que reduz o carbono para formas elementares. Os sistemas de manejo do solo não influenciam esse compartimento.

Pode-se observar a importância do ponto de vista econômico e ecológico da semeadura direta por meio de inúmeros estudos, demonstrando a grande demanda de informação por parte de produtores em relação à pesquisa nesse campo. Oliveira et al. (1998), estudando efeitos de sistemas de preparo periódico do solo na capacidade de campo de um Latossolo em ambiente de cerrado durante as fases fenológicas da cultura de milho, afirmam que a retenção de água foi, em geral, superior na semeadura direta quando comparado ao preparo convencional com arado de disco, seja pelo incremento do seu teor de matéria orgânica, como demonstrado por Santos (1993) em Latossolo, ou ao aumento de microporos e criptoporos (características da compactação do solo), demonstrado por Klein (1998).

Em estudo comparativo com a semeadura convencional, o solo sob semeadura direta apresentou maior capacidade de infiltração, conferindo a este maior aptidão para controlar o escorrimento superficial de água (Machado \& Brum, 1978).

Quando se utiliza o preparo periódico do solo há o fracionamento de agregados. Na semeadura direta, com ausência de preparo e adição de matéria 
orgânica, os agregados se mantém mais estáveis (Corrêa, 2002), diminuindo a susceptividade do solo à compactação. Outra vantagem incontestável da semeadura direta é o recobrimento do solo por restos culturais, protegendo-o dos efeitos da chuva. Em solo descoberto, entre outros fenômenos relacionados principalmente com processos erosivos, pode ocorrer a dispersão de partículas com a força de impacto das gotas, as quais tendem a bloquear seus poros, resultando em uma camada superficial vedada, como descrito por Bonsu (1992).

Condições climáticas extremas durante operações motomecanizadas, juntamente com a expansão da adoção da prática de semeadura direta, têm renovado a preocupação com o processo de compactação (Dias Junior \& Pierce, 1996).

Apesar da prática da semeadura direta acarretar compactação superficial do solo, esta proporcionou melhor adaptação de algumas culturas no Brasil quando comparada à semeadura convencional, como observam Urchei et al. (2000), avaliando cultivares de feijão irrigado em ambas situações. Os autores observaram no primeiro sistema, que o feijoeiro aumentou a produção de matéria seca total, índice de área foliar, taxa de crescimento da cultura, taxa de crescimento relativo, duração da área foliar e a assimilação líquida.

As pesquisas apontam a semeadura direta como uma alternativa interessante, apesar de sua interferência na sua densidade superficial. Efeitos desta interferência nas lavouras são demonstrados por vários trabalhos. Moraes (1988), em estudo de compactação utilizando as classes de solo Argissolo e Latossolo, observou que a penetração e desenvolvimento do sistema radicular de plantas de soja ficaram impedidos quando a densidade global atingiu, para os dois solos, respectivamente valores de 1,30 e 1,23 $\mathrm{g} \cdot \mathrm{cm}^{3}$. Moraes et al. (1998), estudando a influência da compactação nas quantidades de nutrientes para o feijoeiro, concluíram que houve diminuição dos teores de enxofre, boro e zinco com a elevação do nível de compactação em Argissolo. 
Utilizando o penetrômetro para identificar a compactação em um experimento com amendoim e algodão, Taylor \& Gardner (1969) observaram que à medida que o solo se tornava mais compactado, o alongamento das raízes diminuía. Borges et al. (1988) também observaram conseqüências na distribuição e morfologia das raízes pela resistência à penetração do solo. $O$ aumento dos diâmetros e a diminuição dos comprimentos de raízes foram apontados pelos autores como efeitos decorrentes do crescimento das mesmas nos pontos de menor resistência em um solo compactado. Esses sintomas também foram constatados por Guimarães \& Moreira (2001) no estudo de um solo compactado na camada de 0,00 a 0,20 m em uma lavoura de arroz.

Silva Junior (2001), em uma lavoura sob semeadura direta na cultura de milho, observou $15 \%$ de correlação entre a produtividade e o IC na profundidade de $0,10 \mathrm{~m}$ e $12 \%$ na profundidade de $0,15 \mathrm{~m}$. Já em relação à cultura da soja, esta correlação foi de $10 \%$ para o IC a 0,10 m de profundidade e $13 \%$ na profundidade de $0,20 \mathrm{~m}$.

Vazquez et al. (1991) consideram a densidade e a umidade do solo os parâmetros mais importantes que influenciam no IC como um caracterizador do seu estado de compactação. Já o teor de argila, segundo Hakansson et al. (1988); Larson et al. (1980); Mcbride (1989) é uma das propriedades do solo que mais influencia na sua suscetibilidade de compactação, a qual diminui quando os agregados encontram-se mais estáveis.

Dentre os elementos que conferem estabilidade aos agregados, a matéria orgânica tem grande representatividade. Segundo Brady \& Weil (2002), a matéria orgânica favorece a agregação através da junção de partículas minerais em estruturas granulares e pela sua participação na dinâmica da relação entre a estrutura mineral e os organismos do solo, como fungos, bactérias ou até raízes. Estes organismos renovam a matéria orgânica ao serem decompostos e por secretarem exudatos polissacarídeos ou outras colas orgânicas. 
De acordo com Six et al. (2002), a matéria orgânica pode ser estabilizada basicamente pelos mecanismos de estabilização bioquímica, estabilização por associação com argila e silte e proteção física no interior dos agregados. A lignina e polifenois são responsáveis pela estabilização bioquímica da matéria orgânica. A interação da matéria orgânica com silte e argila promove a formação de macroagregados (argilo-minerais) cimentados por interações eletro estáticas entre Fe (III), óxidos de alumínio e suas hidroxilas.

Em relação à estabilização pela proteção da matéria orgânica do solo por agregados, principalmente em relação aos microagregados, os mesmos promovem barreiras físicas entre microorganismos, suas enzimas e o substrato orgânico, além de controlarem interações da cadeia alimentar, influenciando a síntese microbiana, a qual também é parcialmente relacionada à diminuição das concentrações de oxigênio no interior dos poros (Balesdent et al., 2000). Os autores também destacam que a função da fração coloidal da matéria orgânica para armazenamento de nutrientes e água é maior do que esta mesma capacidade da argila, uma vez que da mesma forma, essa fração possui superfície com carga.

Ainda em relação com a estabilidade do solo, Newton \& Drover (1956) já tinham identificado correlação estatística significativa dos colóides orgânicos sobre a agregação em solos de textura arenosa, da mesma forma do que Reichert et al. (1993), os quais posteriormente encontraram correlação positiva significativa entre o carbono orgânico do solo e os índices de estabilidade dos agregados. Este fenômeno foi explicado por Tisdall \& Oades (1982), os quais descrevem a atuação da matéria orgânica na estabilização da formação dos agregados através da ligação de polímeros orgânicos às superfícies inorgânicas através de cátions polivalentes e polímeros hidroximetálicos.

Baver et al. (1972) e Gavande (1972) citam que o efeito da matéria orgânica é menos importante em solos que contém grandes quantidades de argila. Por sua vez, a menor susceptividade dos solos à compactação devido ao 
incremento de matéria orgânica foi observado por Etana et al. (1997) e Assouline et al. (1997).

A compactação do solo pode alterar seu regime de água, como observado por Borges et al. (1999), os quais demonstraram a redução linear, tanto da porosidade total como do espaço de aeração, observando o aumento na mesma magnitude dos conteúdos volumétricos de sólidos e água em estudo onde foram aplicados níveis de pressão, em laboratório, de 0,00, 5,94, 9,05 e 13,58 MPa em latossolo. Silva (1984), também trabalhando com compactação, observou como conseqüências desta um aumento dos poros menores do que 0,005 mm e diminuição dos maiores do que este tamanho.

Mackie-Danwson et al. (1988), observaram que o armazenamento de água contida no solo tem grande similaridade com a microporosidade, enquanto Faria \& Caramori (1986) afirmam que a quantidade de água efetivamente disponível para as plantas cresce à medida que se aumenta a porosidade total do solo.

Klein (1998), analisando o manejo de um Latossolo em semeadura direta observou elevada variação nos valores de resistência do solo em função da condição de umidades.

Aase at al. (2001) encontraram influência da água do solo no IC, mostrando que a sua resistência à penetração diminui em função do aumento da umidade e aumenta em função da elevação da densidade do solo. O mesmo também foi observado por Imhoff et al. (2000), realizando estudo de compactação do solo em pastagem.

Taylor (1963) observou correlação da penetração de raízes de algodão, densidade e umidade do solo, de tal modo que, com densidade de 1,65 g. $\mathrm{cm}^{-3}$, uma perda de $2,5 \%$ da umidade causou diferença na penetração das raízes de $60 \%$, ou seja, para uma densidade de solo considerada, raízes tiveram maior probabilidade de penetrar no solo quanto maior era a umidade deste até um limite.

Segundo Vaz \& Hopmans (2001), a variabilidade espacial e temporal da umidade dificultam a interpretação dos valores de IC para a aferição do grau de 
compactação do solo, uma vez que, além das duas aferições não serem normalmente efetuadas no mesmo exato local, a variação espacial e temporal da umidade coloca em dúvida a utilização da resistência à penetração como indicador do grau de compactação do solo. Isso motivou o estudo da tentativa de correção da umidade na determinação do IC ao mesmo tempo, através do penetrometro acoplado ao sensor de umidade. Efeitos em relação à interação dos dois fatores também motivaram a tentativa de isolar a umidade na determinação da compactação do solo através da determinação de uma fórmula de predição do IC na capacidade de campo (Newman \& Hummel, 1999).

A umidade do solo, assim como outros atributos, têm variabilidade espacial e temporal. O recente avanço de novas técnicas, que no seu conjunto são denominadas de agricultura de precisão, fornece subsídios para o estudo da variabilidade espacial desses atributos. A geração do mapa individual para os componentes da fertilidade e textura do solo, por exemplo, é uma técnica que tem se tornado popular. Nos Estados Unidos da América, parâmetros físicos do solo, que em última análise se associam à drenagem, têm sido os principais responsáveis pela variabilidade espacial e temporal da produtividade das culturas, ultrapassando em importância a fertilidade do solo (Molin, 2001).

Detecção da variabilidade espacial e temporal de propriedades físicas do solo é obtida através de mapas. Para a geração desses mapas, é necessário atrelar os dados dos parâmetros coletados às coordenadas geográficas de cada ponto, como no caso da confecção dos mapas de isocompactação, onde o parâmetro considerado é o IC.

Os penetrômetros utilizados para medir a resistência do solo à penetração são equipamentos sensíveis às variáveis que influenciam neste fenômeno, como a umidade e textura dos solos, não podendo ser utilizados como substitutos de métodos para medida direta da sua densidade (Herrick \& JONES, 2002). 
A norma estabelecida pela prática de engenharia EP542 da ASAE (Asae, 1999) classifica os penetrômetros em dois tipos: os manuais, que são forçados no solo por um operador segurando a empunhadura do aparelho e os mecânicos, montados em veículos que empregam potência mecânica, hidráulica ou elétrica para forçar o cone contra o solo enquanto o IC e a profundidade são registrados por um sistema de aquisição de dados microprocessado.

O penetrógrafo descrito por Carter (1967), é assim designado por armazenar os resultados da força aplicada em cada profundidade através do IC, utilizando a deflexão de uma mola que transfere o movimento para um gráfico. Carter (1969) foi o primeiro a desenvolver um penetrômetro elétrico através de uma célula de carga e um gerador de sinal. Terry et al. (1952) já haviam descrito um aparelho que registrava a força aplicada através de um sistema de molas, sendo este o primeiro penetrômetro com traçador gráfico.

Dentre os penetrômetros manuais, pode-se classificar os que registram a penetração e a força por meio de traçadores gráficos, os que fazem isso por meio de molas ou válvulas de pressão, podendo ou não serem constituídos de um sistema eletrônico, e os de impacto. Para a haste desse último penetrar no solo, o sistema recebe tantos impactos quantos necessários através de um peso padrão liberado a uma altura também padrão (Silva Junior, 2001). Folegatti et al. (1990), comparando os resultados da avaliação da resistência do solo à penetração obtidos pelo penetrômetro de impacto com os do penetrógrafo de mola, concluíram que as medições desse último foram menos variáveis e mais coerentes com a situação de campo.

Lanças et al. (2000) demonstraram a aquisição de dados de IC por meio de um sistema composto por um penetrômetro hidráulico-eletrônico, GPS e programas computacionais. Concluíram que ao gerar mapas de isocompactação do solo, diferenças existentes entre regiões representadas pelos diversos pontos amostrais levantados na área são demonstradas, sendo este um método prático. 
Adamchuk et al. (2001) desenvolveram e testaram uma haste rígida de deslocamento horizontal, instrumentada com célula de carga associada a um GPS, que realiza medições dinâmicas da resistência mecânica à passagem da haste em um solo em três profundidades. O equipamento pode gerar informações para a confecção de mapas que mostram a variação da resistência mecânica, a qual é reflexo dos efeitos da compactação. Em ensaio de campo os autores obtiveram boa correlação entre o IC do penetrômetro e o resultado obtido pela haste.

Para a geração dos dados de posição necessários à confecção de mapas de atributos do solo utiliza-se atualmente o sistema GPS que, segundo Blitzkow (1995), é provido de 24 satélites operacionais e três de reserva, denominados NAVSTAR ("Navigation System with Time and Ranging"), estando distribuídos em 6 órbitas distintas a uma altitude aproximada de $20.200 \mathrm{~km}$ do plano orbital, tendo uma inclinação de $55^{\circ}$ em relação ao plano equatorial, com um período de 12 horas siderais para desenvolver uma volta completa em torno da Terra.

Para a confecção dos mapas após a obtenção dos dados georreferenciados, é necessária a utilização de um sistema de informação geográfica (SIG), definido por Burrough (1986) como um poderoso elenco de ferramentas para colecionar, armazenar, recuperar, transformar e exibir dados espaciais referenciados ao mundo real.

$\mathrm{Na}$ confecção do mapa que demonstra a espacialidade de um atributo do solo, é preciso quantificar o valor de pontos não amostrados através de interpolação dos dados próximos a estes. Para tanto pode-se utilizar a abordagem geoestatística, a qual leva em conta a interferência espacial entre as grandezas medidas. Segundo Braga (1990), esta ciência consiste na interpretação probabilística da teoria das variáveis regionalizadas, formalizada por Georges Mathéron a partir de trabalhos desenvolvidos em atividade de mineração. Pontes (2002) afirma que com o avanço das pesquisas no setor agrícola, atualmente são necessárias áreas cada vez maiores para a 
implementação dos experimentos, sendo que a geoestatística com o seu método que modela diretamente a correlação espacial, passa a ser uma ferramenta indispensável no desenvolvimento dessas pesquisas.

Molin et al. (2001), comparando o efeito de dados de fertilidade do solo com a produtividade, utilizando dados não interpolados e interpolados através de critérios geoestatísticos, observaram semelhança nos resultados obtidos, apesar de constatarem atenuações desses pela interpolação. 


\section{MATERIAL E MÉTODOS}

As áreas de estudo constituem-se de três glebas, sendo uma pertencente à Fundação $A B C$, no município de Castro (PR), com 22,3 ha e 22 anos sob semeadura direta, denominada de área 1 , outra localizada no município de Campos Novos Paulista (SP), com 22,2 ha e 9 anos sob semeadura direta, denominada de área 2 e uma terceira localizada no município de Tibaji (PR), com 21,0 ha e 10 anos sob semeadura direta, denominada como área 3.

As áreas 1 e 3 localizam-se em uma região de clima denominado pela classificação de Köppen, como Cfb, onde predomina a temperatura moderada com chuva bem distribuída e verão brando. Nestes locais podem ocorrer geadas, tanto no inverno como no outono. As médias de temperatura são inferiores a $20^{\circ} \mathrm{C}$, exceto no verão, e no inverno a média é inferior a $14^{\circ} \mathrm{C}$, com mínimas inferiores a $8^{\circ} \mathrm{C}$. A área 2 encontra-se em região cujo o clima, pela mesma classificação, é denominado como Cwa, o qual apresenta temperaturas moderadas com verão quente e chuvoso. No mês mais frio a média de temperatura é inferior a $20^{\circ} \mathrm{C}$.

Em todas as áreas foram feitas amostragens do solo para extrair informações sobre as suas propriedades físicas utilizando-se amostras dispostas em uma grade regular confeccionada a partir do SIG SStoolbox (SST Development Group, Inc. $\left.{ }^{\circledR}\right)$. Escolheu-se a grade regular, uma vez que, segundo Mcbratney \& Webster (1983), esta é a mais apropriada em situações nas quais não se conhece os parâmetros do semivariograma da área de estudo. 
Para se proceder a coleta das amostras foi necessário adaptar os procedimentos executados à logística da propriedade, uma vez que as áreas estudadas são utilizadas para fins comerciais e as atividades de colheita e semeadura não podiam ser cessadas. Em decorrência desta situação foi necessário utilizar uma densidade amostral diferente para cada um dos parâmetros em cada uma das áreas de estudo, visando com isto adaptar o tempo disponível à execução dos procedimentos da investigação científica à logística da produção agrícola.

A alocação das amostras nas áreas 1 e 3 foi executada utilizando-se um receptor de GPS com correção diferencial em tempo real, através de duas antenas da marca OmniStar ${ }^{\circledR}$, respectivamente receptando os sinais provindos da constelação de GPS e do satélite geoestacionário para a correção do primeiro sinal. A navegação até os pontos de amostragem previamente definidos executou-se por meio do programa Farm Site Mate (Farm Works Software ${ }^{\circledR}$ ), executado através de um computador de mão iPAQ (Compaq ${ }^{\circledR}$ ) conectado ao receptor, sendo o sistema alimentado por uma bateria de 12 volts. A navegação na área 2 foi executada utilizando-se o mesmo aparato relacionado aos programas, computadores e métodos, mas utilizou-se um receptor de GPS da marca Garmin ${ }^{\circledR}$, sem sinal diferencial.

Os dados de IC foram coletados em todas as áreas do estudo, utilizadose para tanto o penetrômetro hidráulico eletrônico desenvolvido pelo Departamento de Engenharia Rural da ESALQ/USP, e constituído de um cilindro hidráulico, uma haste conectada a uma célula de carga de marca Gefran, modelo TG61-501 e capacidade de 4903N, um sensor potenciométrico linear, também de marca Gefran, modelo PCM-750 E de até $10 \mathrm{~K} \Omega$. Estes são conectados a um computador portátil, coletando os dados e gerando um gráfico instantaneamente para visualização e conferência a partir do programa Penet, executado em linguagem DELPHI. A potência hidráulica requerida para a inserção e retirada da haste do solo pelo cilindro hidráulico é provida pelo 
controle remoto do sistema hidráulico do trator ao qual o conjunto é rigidamente montado por meio do engate de três pontos.

O equipamento possibilita que sejam coletados oito dados de pressão e profundidade por segundo. A ponta utilizada para inserção no solo obedece as características estruturais e operacionais definidas pela norma ASAE S313.3, ou seja, é constituída por um cone circular com diâmetro de $12,83 \times 10^{-3} \mathrm{~m}$, construída de aço inoxidável, com ângulo do vértice de $30^{\circ} \mathrm{e}$ em cuja base se acopla uma haste de acionamento com diâmetro de $9,53 \times 10^{-3} \mathrm{~m}$. A superfície circular da secção transversal da base do cone tem $1,3 \times 10^{-4} \mathrm{~m}^{2}$. A velocidade de inserção da haste no solo foi calibrada em $0,03 \mathrm{~m} . \mathrm{s}^{-1}$ por meio das válvulas do fluxo hidráulico do próprio equipamento e da regulagem da válvula de acionamento do fluxo do controle remoto do trator, utilizando-se para tanto marcações na alavanca de acionamento do sistema hidráulico. Os dados coletados foram tratados através de uma planilha Microsoft Excel ${ }^{\circledR}$ e foram organizados em profundidades a cada $0,05 \mathrm{~m}$, sendo estes calculados a partir da média de todas as leituras do equipamento no intervalo. Na Figura 1 é ilustrado o referido penetrômetro acoplado a um trator.

$\mathrm{Na}$ área 1 e 2, foram avaliados e correlacionados o IC, o teor de água, teor de argila e teor de silte do solo, e na área 3, além destes parâmetros, também incluiu-se no estudo o teor de matéria orgânica, densidade e porosidade do solo.

As amostras de solo deformadas foram coletadas através de um trado holandês, e posteriormente georreferênciadas. Estas foram utilizadas para a determinação do teor de água, argila, silte e matéria orgânica do solo.

As amostras do solo indeformadas foram coletadas por um amostrador, utilizando-se para tanto anéis volumétricos com volume médio de $55 \mathrm{~cm}^{3}$. As mesmas foram utilizadas para a determinação da densidade e porcentagem do espaço poroso do solo. 


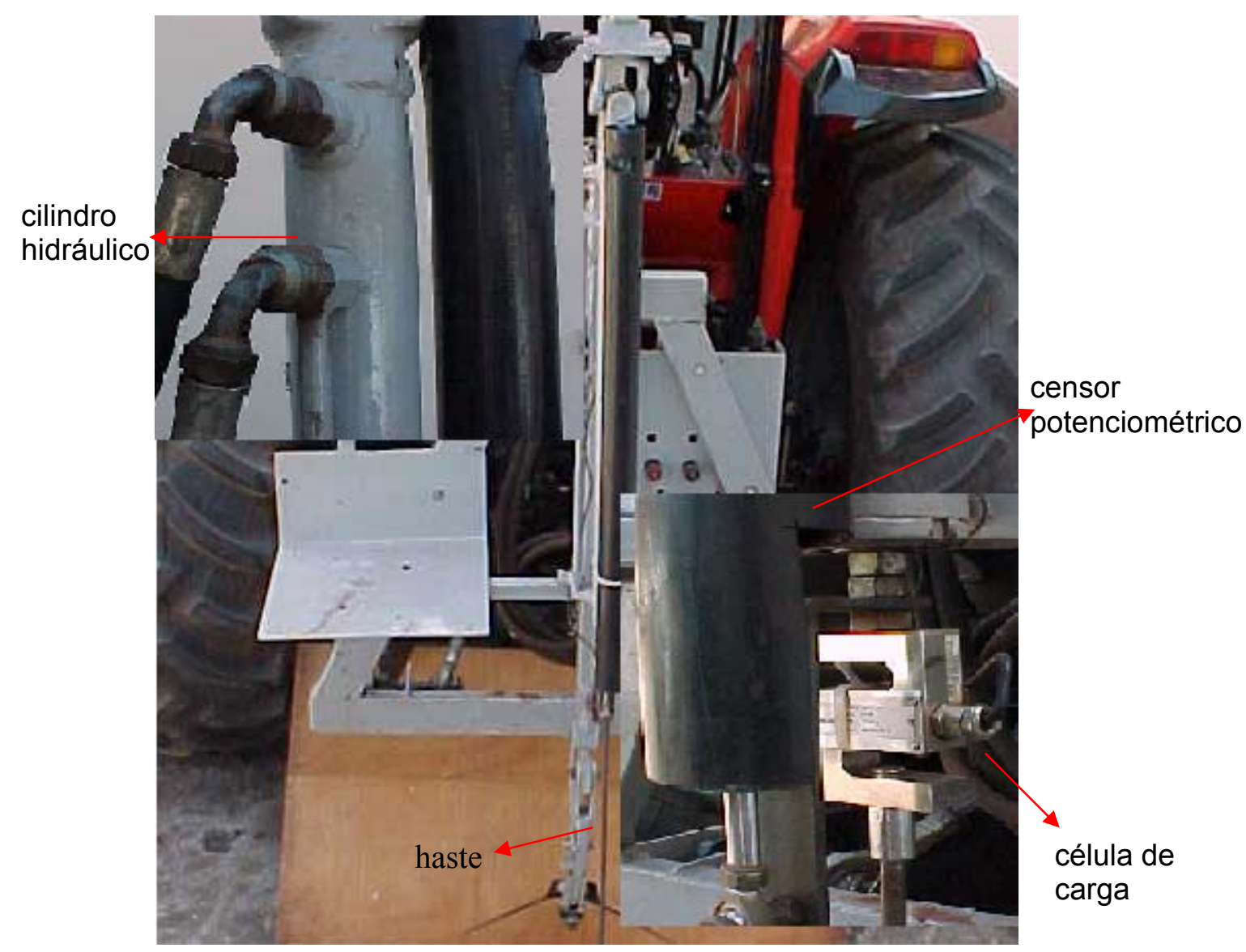

Figura 1 - llustração do penetrômetro com detalhe para as partes mais importantes.

Para a análise do teor de água do solo, utilizou-se o método gravimétrico, que consiste na pesagem anterior e posterior à secagem em estufa a $105^{\circ} \mathrm{C}$ por 24 horas (Blake \& Hartge, 1986). Os dados do IC e a amostragem do solo relacionada à aquisição do seu teor de água foram coletados no mesmo dia, simultaneamente em todos os casos.

Em todas as áreas o teor de argila do solo foi determinado pelo método do hidrômetro, descrito por Day (1965) e modificado por Gee \& Bauder (1986), e o teor de silte foi aferido por diferença. O teor de matéria orgânica, quantificado para a área 3 , foi analisado por meio do método de Walkley Black modificado (Jackson, 1982), inserido no manual de métodos de análise de solo (Embrapa, 1997). 
De forma semelhante à análise do teor de água, ou seja, secando as amostras em estufa a $105^{\circ} \mathrm{C}$ por 24 horas, foi feita a determinação da densidade do solo na área 3 (Blake \& Hartge, 1986), diferenciado pelo fato desta última ser coletada através de anéis com volume conhecido, sendo o peso deste anel descontado de ambas as pesagens. Após a coleta, as amostras de solo georreferenciadas foram armazenadas em sacos plásticos vedados e numerados e as determinações foram executadas parcialmente no laboratório de Implantação de Culturas do Departamento de Engenharia Rural e outra parte no laboratório de Física do Solo do Departamento de Solos e Nutrição de Plantas da ESALQ/USP.

A densidade das partículas também foi quantificada para a área 3, subsidiando assim a determinação do espaço poroso do solo. Tal quantificação foi efetuada através do solo remanescente nos anéis volumétricos utilizados na determinação da sua densidade. O método utilizado foi o do picnômetro a água, descrito por Blake (1965), o qual consta na determinação da densidade das partículas utilizando um frasco de vidro com tampa de mesmo material, uma câmara a vácuo, água destilada e uma balança. Neste experimento foi utilizada a balança de precisão com quatro dígitos, da marca OHAUS ${ }^{\circledR}$.

A obtenção dos valores de espaço poroso do solo foi feita pela relação existente entre densidade do solo e das partículas, encontrando assim a sua porosidade total.

A grade amostral da penetrometria na área 1 teve densidade média de 10,2 amostras por hectare, com distância entre amostras de $30 \mathrm{~m}$; aquela relacionada ao teor de água teve 2,7 amostras por hectare, com distância entre amostras de $59 \mathrm{~m}$; e a relacionada ao teor de argila e silte teve 2,5 amostras por hectare, com distância entre amostras de $60 \mathrm{~m}$. As amostras do teor de água foram coletadas nas profundidades de 0,0 a $0,2 \mathrm{~m}$ e de 0,2 a $0,4 \mathrm{~m}$ da superfície e as relacionadas ao teor de argila e silte foram coletadas na profundidade de 0,0 a $0,2 \mathrm{~m}$, utilizando-se neste caso 7 sub amostras por ponto. 
A grade amostral da penetrometria na área 2 foi efetuada com 5,7 amostras por hectare com distância entre amostras de 40,2 m; aquela relacionada ao teor de água, com 1,5 amostras por hectare, com distância entre amostras de 80,0 m; e a referente ao teor de argila e silte, com 4,2 amostras por hectare, com distância entre amostras de 50,0 m, utilizando-se neste caso, sete sub amostras por ponto. A determinação do teor de água do solo foi efetuada com amostras coletadas na profundidade de 0,0 a 0,3 metros da superfície, e as relacionadas ao teor de argila, com os valores das profundidades de 0,0 a 0,4 $\mathrm{m}$ da superfície.

A grade amostral média do IC na área 3 contem 6,7 mensurações por hectare, com distância entre amostras de $35,5 \mathrm{~m}$; a relacionada ao teor de água, densidade e espaço poroso do solo apresenta 4 amostras por hectare, com distância entre amostras de 50,5 m; e a relacionada ao teor de argila, silte e matéria orgânica do solo apresenta 2,0 amostras por hectare, com distância entre amostras de 71,0 m. A determinação do teor de água do solo foi efetuada com amostras coletadas nas profundidades de 0,0 a 0,20 e de 0,2 a 0,4 m; aquelas relativas à densidade e espaço poroso do solo, na profundidade de 0,15 a 0,20 m e as relacionadas ao o teor de argila, silte e matéria orgânica, na profundidade de 0,0 a 0,2 m, utilizando-se para estas últimas, 7 sub amostras.

Para promover a coincidência da profundidade dos valores de IC com os demais atributos do solo estudados, foi quantificada a média deste índice para o intervalo requerido, uma vez que estes dados apresentavam-se em um primeiro momento, fragmentados a cada 0,05 $\mathrm{m}$. Com esta etapa, pode-se quantificar os valores e IC médio, nas áreas 1 e 3 , nas profundidades de 0,0 a 0,2 e de 0,2 a 0,4; e na área 2, nas profundidades de 0,0 a 0,3 e de 0,0 a 0,4.

Para a análise estatística descritiva dos dados coletados, foi utilizado o programa Statistica (StatSoft $I n c^{\circledR}$ ), sendo que as análises geoestatísticas foram executadas pelo programa Vésper 1.5 (Minasny et al., 2002).

Transformou-se os dados brutos que não apresentaram normalidade objetivando a obtenção da distribuição normal, verificada pelo método descrito 
por Shapiro \& Wilk (1965), utilizando-se para tanto a retirada daqueles dados candidatos a discrepantes e a transformação do conjunto de dados através de constantes como o logaritmo na base 10, a raiz quadrada e o seno hiperbólico do inverso da raiz quadrada. A partir dos dados tratados, com os quais foi possível a distribuição normal, foi feita a análise geo-estatística, e para os atributos em que também foi constatada a continuidade espacial, foram calculados os valores de seminvariância na construção do semivariograma, o qual foi ajustado e seus parâmetros - efeito pepita, alcance, patamar e função utilizados para a realização da interpolação e construção de mapas através da krigagem. Para os demais atributos, que não apresentaram distribuição normal ou continuidade espacial por terem o efeito pepita puro (valores de semivariância iguais para o efeito pepita e patamar), ou para aqueles que apresentaram modelo sem patamar (alcance e patamar não puderam ser aferidos com a amostragem efetuada), utilizou-se para a geração dos mapas, o método de interpolação do inverso da distância. Este método ignora a existência da dependência espacial e, portanto, não leva em consideração parâmetros da geoestatística. Os mapas foram gerados com o programa SIG SStoolbox (SST Development Group, Inc. ${ }^{\circledR}$ ) com células de $5 \mathrm{~m}$, cujos valores foram utilizados nas análises de regressão entre os fatores, nas quais foi ajustado o modelo que apresentou maior coeficiente de determinação $\left(R^{2}\right)$, ou seja, melhor explicação dos dados pelo modelo. Utilizou-se o programa Excel $\left(\right.$ Microsoft $\left.{ }^{\circledR}\right)$ para a execução das regressões e ajuste dos modelos.

As regressões efetuadas nas áreas 1 e 2, relacionam-se ao IC com os teores de água, argila e silte; e ao teor de água com os teores de argila e silte. $\mathrm{Na}$ área 3, além das regressões já executadas para as áreas 1 e 2 , contemplou-se também aquelas relacionadas ao IC com o teor de matéria orgânica, densidade e espaço poroso do solo; teor de matéria orgânica com os teores de água, argila e silte do solo; e entre a densidade e espaço poroso com os teores de água, argila, silte e matéria orgânica do solo. 


\section{RESULTADOS E DISCUSSÃO}

A Tabela 1 ilustra a análise estatística dos resultados dos atributos a diferentes profundidades, coletados na área 1, assim como o índice de aproximação dos dados a uma curva de distribuição normal teórica calculada pelo método de Shapiro \& Wilk (1965).

Analisando o histograma dos dados, no qual, além da freqüência de ocorrência plotou-se a curva de distribuição normal para cada conjunto, constatou-se que alguns destes se afastavam da curva e diminuíam a aproximação do conjunto a ela. Estes dados foram considerados candidatos a discrepantes, e por causa disto, foram retirados na fase da análise geoestatística para não interferirem na aquisição dos parâmetros do semivariograma.

Os dados de IC nas profundidades de 0,25 a $0,30 \mathrm{~m}$ e os de teor de argila na profundidade de 0,00 a 0,20 m alcançaram a distribuição normal após a retirada daqueles candidatos a discrepantes, apresentando, em ambos os casos, um coeficiente de semelhança com a curva de distribuição normal W de 0,96 . Nas faixas de 0,30 a 0,35 m, 0,35 a 0,40 m e 0,20 a 0,40 m, os dados de IC apresentaram distribuição normal somente após a retirada dos dados candidatos a discrepantes e transformação destes através do logaritmo na base 10 , apresentando um índice $W$ de 0,98 nas duas primeiras profundidades e de 0,99 na última. Utilizando-se todos os conjuntos de dados, após todos os procedimentos necessários para ajuste destes à distribuição normal, foram confeccionados semivariogramas, ilustrados no Anexo $A$, os quais têm seus parâmetros tabulados na Tabela 2. 
Tabela 1. Parâmetros da estatística descritiva referentes ao IC e teor de água para a área 1

\begin{tabular}{|c|c|c|c|c|c|c|c|}
\hline $\begin{array}{l}\text { Profundidade } \\
\text { (m) }\end{array}$ & Média & Mínimo & Máximo & Variância & $\begin{array}{l}\text { Desvio } \\
\text { Padrão }\end{array}$ & $\begin{array}{l}\text { Coef. de } \\
\text { variação }\end{array}$ & $W^{*}$ \\
\hline \multicolumn{8}{|c|}{ IC (MPa) } \\
\hline 0,00 a 0,05 & 0,93 & 0,36 & 2,07 & 0,08 & 0,28 & 30,11 & $0,96^{* *}$ \\
\hline 0,05 a 0,10 & 1,36 & 0,50 & 2,47 & 0,10 & 0,31 & 22,79 & $0,99^{* *}$ \\
\hline 0,10 a 0,15 & 1,45 & 0,73 & 2,63 & 0,08 & 0,29 & 20,00 & $0,98^{* *}$ \\
\hline 0,15 a 0,20 & 1,33 & 0,49 & 2,43 & 0,09 & 0,30 & 22,56 & $0,97^{* *}$ \\
\hline 0,20 a 0,25 & 1,26 & 0,40 & 2,71 & 0,11 & 0,33 & 26,19 & $0,95^{* *}$ \\
\hline 0,25 a 0,30 & 1,21 & 0,43 & 2,95 & 0,15 & 0,39 & 32,23 & 0,91 \\
\hline 0,30 a 0,35 & 1,20 & 0,57 & 3,15 & 0,20 & 0,44 & 36,66 & 0,89 \\
\hline 0,35 a 0,40 & 1,20 & 0,49 & 4,30 & 0,29 & 0,54 & 45,00 & 0,83 \\
\hline 0,00 a 0,20 & 1,27 & 0,71 & 2,12 & 0,05 & 0,22 & 17,32 & $0,97^{* *}$ \\
\hline 0,20 a 0,40 & 1,22 & 0,65 & 2,91 & 0,14 & 0,38 & 31,15 & 0,89 \\
\hline \multicolumn{8}{|c|}{ Teor de água (\%) } \\
\hline 0,00 a 0,20 & 36,75 & 29,69 & 43,06 & 4,97 & 2,22 & 6,04 & $0,96^{* *}$ \\
\hline 0,20 a 0,40 & 39,03 & 31,84 & 47,53 & 10,17 & 3,19 & 8,17 & $0,99^{* *}$ \\
\hline \multicolumn{8}{|c|}{ Teor de argila $(\%)$} \\
\hline 0,00 a 0,20 & 41,07 & 16,90 & 52,40 & 57,60 & 7,59 & 18,48 & 0,94 \\
\hline \multicolumn{8}{|c|}{ Teor de silte (\%) } \\
\hline 0,00 a 0,20 & 27,81 & 13,20 & 42,00 & 41,75 & 6,46 & 23,23 & $0,98^{* *}$ \\
\hline \multicolumn{8}{|c|}{$\begin{array}{l}\text { * Índice de aproximação dos dados a curva de distribuição normal pelo teste de Shapiro \& Wilk } \\
(1965) \text {. } \\
\text { ** dados que apresentaram a distribuição normal a nível de significância }(\alpha) \text { de } 0.05(5 \%)\end{array}$} \\
\hline \multicolumn{8}{|c|}{$\begin{array}{l}\text { Todos os dados de dependência espacial encontrados mostraram-se } \\
\text { fortes segundo a classificação apontada por Cambardella et al. (1994), o qual } \\
\text { estabelece que quando o valor percentual do efeito pepita em relação ao valor } \\
\text { máximo da semivariância é menor do que } 25 \% \text {, esta dependência pode ser } \\
\text { considerada forte, quando esta relação assume grandezas entre } 25 \text { a } 75 \% \text {, } \\
\text { moderada, e quando a mesma apresenta-se maior do que } 75 \% \text {, fraca. }\end{array}$} \\
\hline
\end{tabular}


Tabela 2. Parâmetros do semivariograma para IC e umidade referentes à área 1

\begin{tabular}{|c|c|c|c|c|c|c|}
\hline Profundidade (m) & $\begin{array}{l}\text { Efeito pepita } \\
\text { (CO) }\end{array}$ & $\begin{array}{l}\text { Patamar } \\
(\mathrm{CO}+\mathrm{C} 1)\end{array}$ & $\begin{array}{c}\text { Alcance } \\
(\mathrm{m})\end{array}$ & Função & $\begin{array}{c}\frac{\mathrm{CO} \times 100}{\mathrm{CO}+\mathrm{C} 1} \\
(\%)\end{array}$ & Observação \\
\hline \multicolumn{7}{|c|}{ IC } \\
\hline 0,00 a 0,05 & .. & .. & .. & .. & .. & Efeito Pepita Puro \\
\hline 0,05 a 0,10 & .. & .. & .. & .. & .. & Efeito Pepita Puro \\
\hline 0,10 a 0,15 & .. & .. & .. & .. & .. & Efeito Pepita Puro \\
\hline 0,15 a 0,20 & .. & .. & .. & .. & .. & Efeito Pepita Puro \\
\hline 0,20 a 0,25 & .. & .. & .. & .. & .. & Efeito Pepita Puro \\
\hline 0,25 a 0,30 &.. &.. &.. & .. & .. & Efeito Pepita Puro \\
\hline 0,30 a 0,35 & 0,0 & 1,05 & 16,3 & Exponencial & 0,0 & \\
\hline 0,35 a 0,40 &.. &.. &.. &.. &.. & Efeito Pepita Puro \\
\hline 0,00 a 0,20 & .. &.. &.. & .. & .. & Efeito Pepita Puro \\
\hline 0,20 a 0,40 & .. &.. &.. &.. & .. & Efeito Pepita Puro \\
\hline \multicolumn{7}{|c|}{ Teor de água } \\
\hline 0,00 a 0,20 &.. &.. &.. & .. & .. & Efeito Pepita Puro \\
\hline 0,20 a 0,40 & 0,0 & 928,0 & 53,8 & Esférico & 0,0 &.. \\
\hline \multicolumn{7}{|c|}{ Teor de argila } \\
\hline 0,00 a 0,20 & 8,0 & 44,6 & 362,0 & Esférico & 17,9 & .. \\
\hline \multicolumn{7}{|c|}{ Teor de silte } \\
\hline 0,00 a 0,20 & 7,0 & 52,0 & 422,0 & Exponencial & 13,5 & .. \\
\hline
\end{tabular}


Para os dados de IC nas profundidades da superfície até $0,30 \mathrm{~m}$, de 0,35 a $0,40 \mathrm{~m}$, de 0,00 a 0,20 , de 0,20 a 0,40 e para aqueles relacionados à umidade na profundidade de 0,00 a 0,20 não se tabulou os parâmetros do semivariograma, uma vez que estes dados não tiveram continuidade espacial, e por este motivo para os mesmos foi feita a interpolação dos dados utilizandose o método do inverso da distância. Para os demais dados, procedeu-se a interpolação efetuada através da krigagem levando em consideração os parâmetros tabulados na Tabela 2. Tanto para a faixa de profundidade do IC a qual detectou-se dependência espacial quanto para os teores de argila e silte, o alcance foi maior do que a distância entre as amostras no campo, o que demonstra a suficiência da amostragem destes atributos para a detecção da continuidade espacial dos mesmos.

Em relação ao teor de água, o alcance foi menor do que a distância entre as amostras no campo, o que potencializa as dificuldades na análise dos resultados, uma vez que para tais condições, este é um indício de que a amostragem foi insuficiente para proporcionar um bom ajuste dos dados interpolados (Macbratney \& Webster, 1981). O resultado gráfico desta análise encontra-se ilustrado na Figura 2.

Pela análise dos mapas constatou-se um maior IC na profundidade de 0,05 a $0,15 \mathrm{~m}$, com maior concentração na faixa de profundidade de 0,10 a $0,15 \mathrm{~m}$. A profundidades maiores do que 0,20 m, mesmo com umidade menor, o IC foi generalizadamente menor, apresentando alguns picos com valor mais elevado do que nas demais áreas. Atribui-se este fato à tendência da ocorrência de solo mais compactado superficialmente, a qual também foi identificada nesta mesma área por Silva Júnior (2001), que também observou valores de IC dispersos e com poucas zonas semelhantes e contínuas.

Apesar de haver certa tendência no mapa de maior teor de água a oeste do talhão, onde há maior teor de argila, não foi possível estabelecer uma área de coincidência definida para estes atributos na profundidade de 0,00 a 0,20, na qual o teor de água era mais elevado. Nota-se que a área com maior teor de 
água na profundidade de 0,20 a 0,40 m coincide com a área com maior teor de argila na profundidade de 0,00 a 0,20 m. Supõem-se que esta, por sua vez, também deve seguir distribuição semelhante na profundidade de 0,20 a 0,40 m.

O resultado das fórmulas derivadas do ajuste de modelos pela regressão entre os atributos do solo, assim como o coeficiente de determinação (R2), encontram-se tabulados na Tabela 3.

Tabela 3. Índice de correlação entre os dados interpolados dos parâmetros estudados na área 1

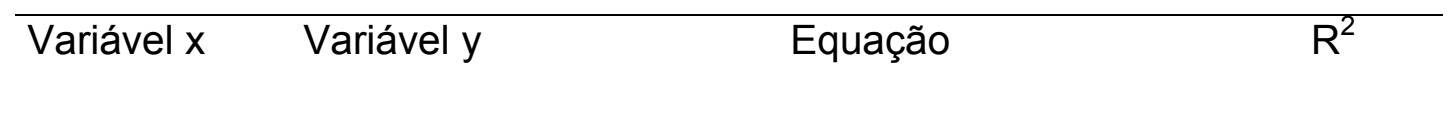

\section{Profundidade de 0,0 a $0,2 \mathrm{~m}$}

\begin{tabular}{|c|c|c|c|}
\hline $\begin{array}{l}\text { Teor de } \\
\text { água }\end{array}$ & IC & $Y=-0,0014 x^{2}+0,1085 x-0,8404$ & 0,0701 \\
\hline $\begin{array}{l}\text { Teor de } \\
\text { argila }\end{array}$ & IC & $Y=0,0003 x^{2}-0,0278 x+1,8602$ & 0,0520 \\
\hline Teor de silte & IC & $Y=0,0004 x^{2}-0,0163 x+1,4301$ & 0,0832 \\
\hline $\begin{array}{l}\text { Teor de } \\
\text { argila }\end{array}$ & $\begin{array}{l}\text { Teor de } \\
\text { água }\end{array}$ & $Y=0,074 x+33,763$ & 0,1072 \\
\hline Teor de silte & $\begin{array}{l}\text { Teor de } \\
\text { água }\end{array}$ & $Y=-0,0176 x^{2}+1,0138 x+22,827$ & 0,2087 \\
\hline
\end{tabular}

Profundidade de 0,2 a 0,4 m

Teor de água

IC

$Y=3,1937 x^{0,3194}$

0,0701 


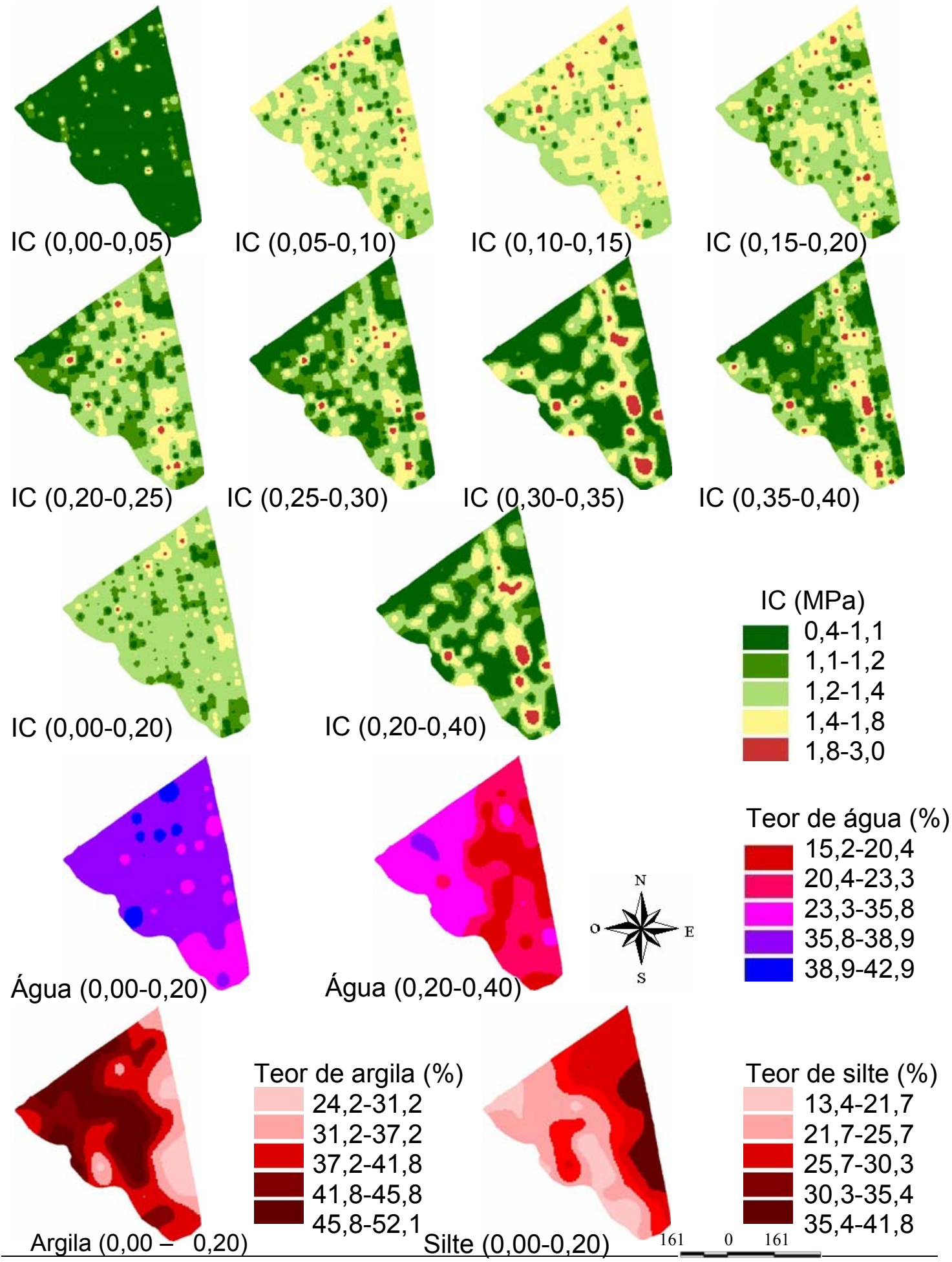

Figura 2 - Mapas dos atributos IC e teor de água do solo, estudados na área 1 , por faixas de profundidade $(\mathrm{m})$ 
Observa-se através dos gráficos das regressões (Anexo D), uma incoerência no comportamento entre o teor de água e o IC na profundidade de 0,0 a 0,2 m, uma vez que a função ajustada, a qual caracteriza-se como um polinômio de segundo grau, no início da curva indica a existência de uma relação proporcional entre os dois parâmetros, em que o aumento do teor de água causa um pequeno aumento do IC, situação que tende à inversão com o aumento do teor de água. Este resultado do início da curva apresenta-se incoerente, uma vez que segundo Vasques et al. (2001); Aase at al. (2001) e Imhoff et al. (2000), espera-se relação inversamente proporcional entre estes dois fatores. Na profundidade de 0,20 a $0,40 \mathrm{~m}$, a regressão entre o IC e a umidade apresentou um resultado mais coerente, pois neste caso houve relação inversamente proporcional entre este índice e a umidade, tendendo à estabilização com o aumento do teor de água.

A incoerência dos dados na profundidade de $0,00 \mathrm{~m}$ a $0,20 \mathrm{~m}$ provavelmente ocorreu devido a outros fatores, os quais não foram contemplados neste estudo e que devem estar atuando para promover mudanças ou camuflar as correlações esperadas, dificultando da mesma forma a visualização da relação causa e efeito esperada nos mapas gerados. Segundo Henderson et al. (1988) a influência da umidade na resistência à penetração do solo, a qual é mensurada pelo IC, não se apresenta de forma linear, sendo que até $70 \%$ da capacidade de campo tal influência é menor, crescendo exponencialmente quando a diminuição da quantidade de água ultrapassa este limite. Mesmo não se pautando em estimativas da quantidade de água em relação à capacidade de campo do solo, uma vez que não se conhece estes dados ou se os mesmos variam verticalmente no perfil do solo, pode se afirmar que a coerência do IC em relação à umidade na profundidade de 0,20 a $0,40 \mathrm{~m}$, possivelmente está relacionada à menor umidade nesta profundidade.

Através do coeficiente de determinação, constatou-se que, em relação à regressão entre o teor de água e o IC na profundidade de 0,00 a 0,20 m, 
apenas $1,1 \%$ dos dados foram explicados pelo modelo, e na profundidade de 0,20 a $0,40 \mathrm{~m}, 7 \%$ destes dados. Este comportamento corrobora as afirmações de Henderson et al. (1988), pois na profundidade de 0,00 a 0,20 m, a aparente inconsistência no gráfico da regressão provavelmente está relacionada à proximidade em que a curva ajustada esteja da estabilização devido à maior quantidade de água no solo, provocando, desta forma, menor influência no IC. Na profundidade de 0,20 a $0,40 \mathrm{~m}$, a curva tendeu à estabilização, e como ainda não havia atingido o seu patamar, o coeficiente de determinação foi sensivelmente maior, indicando que a umidade teve influência na variação do IC.

Os coeficientes de determinação entre os teores de argila e silte e o IC prestaram-se para explicar $5,2 \%$ da variabilidade total no primeiro caso e 8,3 $\%$ no segundo. A regressão ajustada demonstra que onde o IC foi maior, havia menor teor de argila e maior teor de silte. Tal resultado, à primeira vista, poderia ser considerado incoerente, uma vez que, segundo Brady \& Weil (2001), solos mais argilosos são mais susceptíveis à compactação. Por outro lado, estes também tem maior capacidade em armazenar água, a qual diminui a resistência à penetração do solo, e pode potencialmente camuflar os efeitos desta compactação mensurados pelo IC. A argila, portanto, tem potencial em disciplinar a água para os solos mais argilosos, e isto pode ser observado através da regressão entre estes dois atributos, a qual seguiu um comportamento linear, com coeficiente de determinação prestando-se para explicar $10,7 \%$ da variabilidade total, em que o teor de água aumenta de maneira diretamente proporcional ao aumento do teor de argila do solo.

$\mathrm{Na}$ Tabela 4 são apresentados os dados relacionados à estatística descritiva da área 2.

Os dados de IC na profundidade de 0,00 a 0,05 m não apresentaram distribuição normal, o que demandou o seu tratamento por meio da retirada de valores candidatos a discrepantes e da aplicação, nos dados transformados, do seno hiperbólico do inverso da raiz. Após estes procedimentos os dados 
ajustaram-se a esta distribuição, uma vez que o teste aplicado revelou o valor de $\mathrm{W}$ igual a 0,99 .

Os demais dados, que inicialmente também não tinham apresentado distribuição normal, passaram a apresentar tal distribuição após a retirada, da mesma forma, daqueles candidatos a discrepantes, apresentando nesta situação, para os dados de IC na profundidade de 0,30 a 0,35 m, valor de W igual a 0,97, e em relação à umidade de 0,00 a 0,30 m, valor de $W$ igual a 0,96.

Tabela 4. Parâmetros da estatística descritiva referentes ao IC, teor de água e teor de argila para a área 2

\begin{tabular}{|c|c|c|c|c|c|c|c|}
\hline $\begin{array}{l}\text { Profundidade } \\
\text { (m) }\end{array}$ & Média & Mínimo & Máximo & Variância & $\begin{array}{l}\text { Desvio } \\
\text { Padrão }\end{array}$ & $\begin{array}{l}\text { Coef, de } \\
\text { variação }\end{array}$ & $W^{*}$ \\
\hline & & & IC & $\mathrm{MPa})$ & & & \\
\hline 0,00 a 0,05 & 1,19 & 0,45 & 3,07 & 0,22 & 0,47 & 39,50 & 0,92 \\
\hline 0,05 a 0,10 & 2,28 & 0,44 & 4,67 & 0,78 & 0,88 & 38,60 & $0,99 * *$ \\
\hline 0,10 a 0,15 & 2,69 & 0,47 & 5,17 & 0,71 & 0,84 & 31,23 & $0,99 * *$ \\
\hline 0,15 a 0,20 & 2,78 & 1,41 & 4,35 & 0,39 & 0,62 & 22,30 & $0,97^{* *}$ \\
\hline 0,20 a 0,25 & 2,52 & 1,24 & 4,67 & 0,29 & 0,54 & 21,43 & $0,96^{* *}$ \\
\hline 0,25 a 0,30 & 2,34 & 1,05 & 4,00 & 0,21 & 0,46 & 19,66 & $0,96^{* *}$ \\
\hline 0,30 a 0,35 & 2,19 & 1,07 & 4,10 & 0,16 & 0,40 & 18,26 & 0,94 \\
\hline 0,35 a 0,40 & 2,09 & 1,02 & 3,82 & 0,18 & 0,43 & 20,57 & $0,98^{* *}$ \\
\hline 0,00 a 0,30 & 2,30 & 1,40 & 3,66 & 0,25 & 0,50 & 21,74 & $0,97^{* *}$ \\
\hline 0,00 a 0,40 & 2,19 & 1,21 & 3,53 & 0,11 & 0,34 & 15,53 & $0,97^{* *}$ \\
\hline & & & Teor de & água (\%) & & & \\
\hline 0,00 a 0,30 & 12,35 & 10,14 & $\begin{array}{c}17,30 \\
\text { Teor de }\end{array}$ & $\begin{array}{c}1,56 \\
\text { argila }(\%)\end{array}$ & 1,25 & 10,12 & 0,85 \\
\hline 0,00 a 0,40 & 24,80 & 17,45 & 29,70 & 8,30 & 2,88 & 11,61 & $0,97^{* *}$ \\
\hline 0,00 a 0,40 & 5,07 & 2,25 & 8,45 & 1,21 & 1,10 & 21,70 & $0,98^{* *}$ \\
\hline
\end{tabular}

Com as transformações efetuadas foi possível a análise através da geoestatística e a aquisição dos parâmetros do semivariograma ajustado, os quais subsidiaram a confecção dos mapas por krigagem daqueles conjuntos de 
dados que apresentaram continuidade espacial e os resultados são apresentados na Tabela 5.

Segundo o critério proposto por Cambardella et al. (1994), a dependência espacial para os dados de IC nas profundidades de 0,20 a 0,25 e 0,25 a 0,30 , assim como para o teor de argila na faixa de 0,00 a 0,40 foi forte e para os dados de IC na profundidade de 0,00 a 0,30 foi fraca. Para os demais dados que apresentaram dependência espacial, esta foi moderada. Nos casos em que foi possível o ajuste do semivariograma o alcance foi maior do que a distância entre as amostras, comprovando a suficiência da amostragem efetuada.

Os dados referentes ao IC na profundidade de 0,15 a 0,20 m e o teor de água na profundidade de 0,00 a $0,30 \mathrm{~m}$, apresentaram continuidade espacial, mas o alcance não pôde ser aferido devido ao patamar do modelo não ter sido alcançado. Mesmo assim houve a suficiência da amostragem efetuada, uma vez que detectou-se a dependência espacial.

Utilizando-se destes parâmetros para os dados que apresentaram continuidade espacial e patamar determinado, foi efetuada a interpolação e geração dos mapas através da krigagem, sendo que os dados que apresentaram o efeito pepita puro (IC nas profundidades de 0,00 a 0,05, 0,05 a $0,10,0,10$ a $0,15,0,35$ a $0,40 \mathrm{~m}$ ) e modelo sem patamar (IC nas profundidades de 0,15 a 0,20 e teor de água na profundidade de 0,00 a $0,30 \mathrm{~m}$ ) foram interpolados pelo método do inverso da distância. O resultado gráfico de todas as interpolações encontra-se ilustrado na Figura 3.

Os maiores valores de IC nesta área estão nas profundidades de 0,10 a $0,20 \mathrm{~m}$, concentrando-se mais precisamente na profundidade de 0,15 a 0,20 m. As áreas com maiores índices localizam-se no centro, tendendo a noroeste do talhão. Neste local também não foi possível uma visualização da relação causa e efeito do IC com os demais atributos do solo, contudo, observa-se relação visual entre o teor de água e o de argila. 
Tabela 5. Parâmetros relativos ao ajuste do semivariograma para IC, teor de água e teor de argila referentes à área 2

\begin{tabular}{|c|c|c|c|c|c|c|}
\hline $\begin{array}{l}\text { Profundidade } \\
\text { (m) }\end{array}$ & $\begin{array}{c}\text { Efeito } \\
\text { pepita (CO) }\end{array}$ & $\begin{array}{l}\text { Patamar } \\
(\mathrm{CO}+\mathrm{C} 1)\end{array}$ & Alcance (m) & Função & $\begin{array}{c}\frac{\mathrm{Co} \times 100}{\mathrm{Co}+\mathrm{C} 1} \\
(\%)\end{array}$ & Observações \\
\hline \multicolumn{7}{|c|}{ IC } \\
\hline 0,00 a 0,05 & .. & .. & .. & .. & .. & Efeito Pepita Puro \\
\hline 0,05 a 0,10 & .. & .. & .. & .. & .. & Efeito Pepita Puro \\
\hline 0,10 a 0,15 & .. & .. & .. & .. & .. & Efeito Pepita Puro \\
\hline 0,15 a 0,20 & .. & .. & .. & .. & .. & Modelo Sem Patamar \\
\hline 0,20 a 0,25 & 0,02 & 0,14 & 57,25 & Exponencial & 14,28 & .. \\
\hline 0,25 a 0,30 & 0,03 & 0,19 & 128,20 & Esférico & 15,79 & .. \\
\hline 0,30 a 0,35 & 0,04 & 0,12 & 183,40 & Esférico & 33,33 & 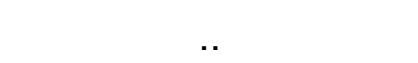 \\
\hline 0,35 a 0,40 & & $\cdot$. & .. & .. & .. & Efeito Pepita Puro \\
\hline 0,00 a 0,30 & 0,14 & 0,18 & 118,30 & Exponencial & 77,77 & .. \\
\hline 0,00 a 0,40 & 0,07 & 0,14 & 629,40 & Exponencial & 50,00 & .. \\
\hline \multicolumn{7}{|c|}{ Teor de água } \\
\hline \multicolumn{7}{|c|}{ "Teor de argila } \\
\hline \multicolumn{7}{|c|}{ Teor de silte } \\
\hline 0,00 a 0,40 & 0,52 & 1,87 & 119,50 & Exponencial & 27,81 & \\
\hline
\end{tabular}




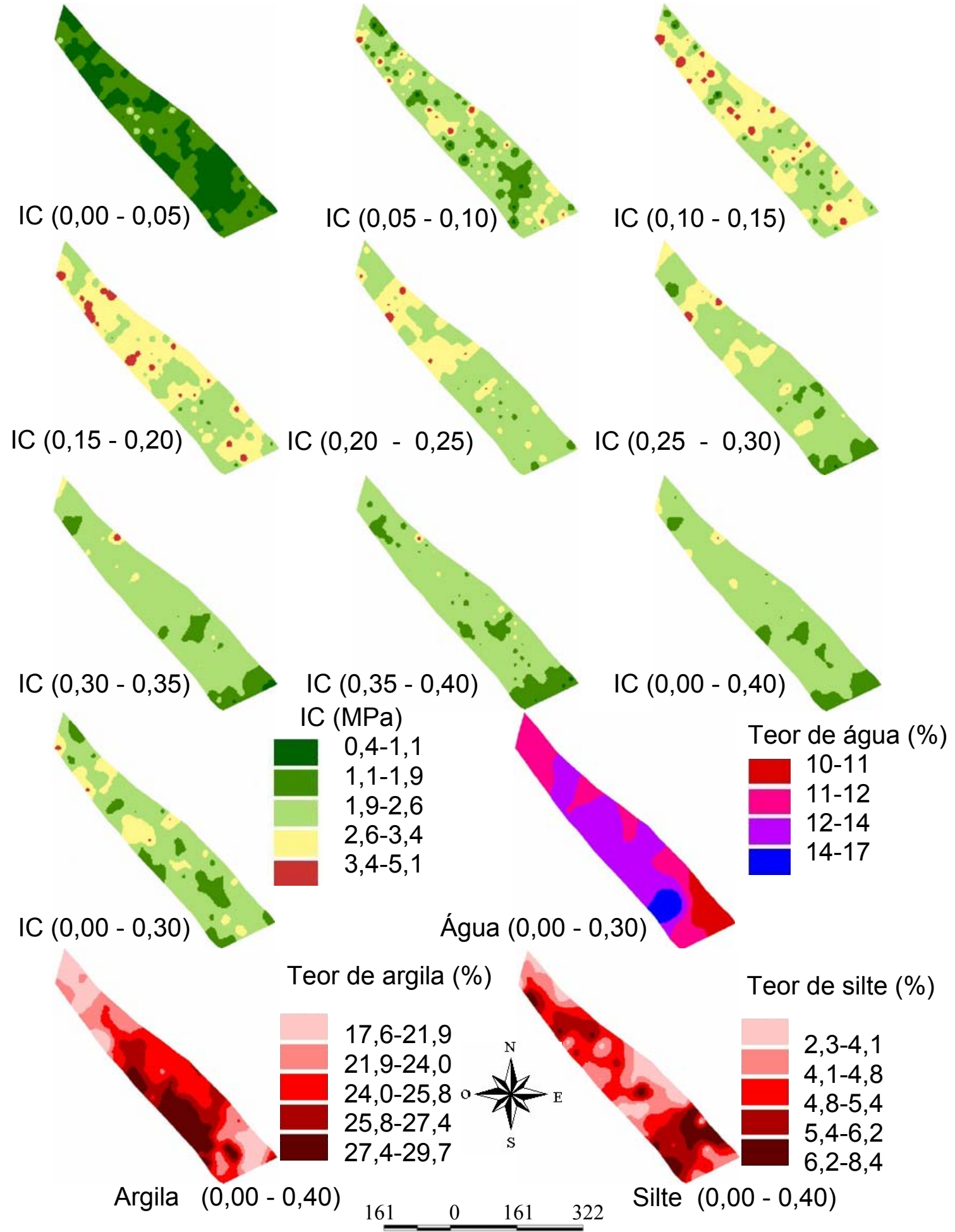

Figura 3 - Mapas dos atributos IC, teor de água e teor de argila do solo, estudados na área 2, por faixas de profundidade $(\mathrm{m})$ 
Onde existe um teor de argila mais elevado, o teor de água também foi maior, sendo este um fenômeno esperado, uma vez que solos com textura mais argilosa têm maior potencial em armazenamento de água do que aqueles mais arenosos (Brady \& Weil, 2001). Estes autores também esclarecem que solos mais argilosos são mais susceptíveis à compactação, mas o teor de água atua reduzindo o valor das leituras de IC. Possivelmente a interação destes fatores resultou em mapas de IC que, à primeira vista, não apresentaram relação com o teor de água.

Outros fatores não estudados na área podem estar influenciando na obtenção destes resultados. Um exemplo é o teor de matéria orgânica, que tende a promover maior estabilidade e diminuir o potencial de compactação do solo. O resultado das regressões é apresentado na Tabela 6.

Tabela 6. Regressão entre os dados interpolados dos parâmetros estudados na área 2

\begin{tabular}{lccc}
\hline Variável $x$ & \multicolumn{2}{c}{$\begin{array}{c}\text { Eariável y } \\
\text { Profundidade de } 0,0 \text { a 0,3 } \mathrm{m}\end{array}$} & $\mathrm{R}^{2}$ \\
\hline Teor de água & IC & $\mathrm{Y}=-0,023 \mathrm{x}^{2}+0,5578 \mathrm{x}-1,0666$ & 0,017 \\
& Profundidade de 0,0 a 0,4 $\mathrm{m}$ & \\
Teor de argila & IC & $\mathrm{Y}=-0,0051 \mathrm{x}^{2}+0,2517 \mathrm{x}-0,8706$ & 0,019 \\
Teor de silte & IC & $\mathrm{Y}=-0,0095 \mathrm{x}^{2}+0,0716 \mathrm{x}+2,0794$ & 0,008 \\
Teor de argila & Teor de água & $\mathrm{Y}=2,6785 \mathrm{x}^{0,4775}$ & 0,382 \\
Teor de silte & Teor de água & $\mathrm{Y}=-0,1402 \mathrm{x}^{2}+1,3724 \mathrm{x}+9,1383$ & 0,026 \\
\hline
\end{tabular}

A curva de regressão entre o IC e o teor de água identifica uma relação inversamente proporcional não linear, a qual não tende à estabilidade com o aumento do teor de água. Esta situação pode estar relacionada ao fato do teor de água não ter alcançado patamares muito elevados.

O IC variou pouco em relação ao teor de argila, e o comportamento deste foi pouco explicado pela função ajustada, a qual foi suficiente para 
explicar apenas 1,9\% dos dados. Neste caso, o IC aumenta com o teor de argila até este atingir o patamar de aproximadamente $25 \%$. Após, há uma inversão na curva polinomial ajustada e o IC decresce na medida que o teor de argila é crescente. Entre o IC e o teor de silte do solo, constatou-se o mesmo comportamento encontrado para o teor de argila, porém explicado apenas em $2,6 \%$ da variabilidade dos dados.

Já em relação ao teor de água e o de argila, como era de se esperar, através da análise dos mapas, houve um comportamento diretamente proporcional, uma vez que houve o disciplinamento da água para locais com maiores teores de argila no talhão. A regressão entre teor de água e argila resultou em uma função suficiente para explicar $38,2 \%$ da variabilidade dos dados.

Os parâmetros estatístico dos resultados obtidos na área 3 encontramse na Tabela 7. Depois de removidos os dados candidatos a discrepantes de todos os valores de IC que não apresentaram distribuição normal, aqueles das profundidades de 0,15 a 0,20, 0,20 a 0,25 e 0,25 a 0,30 m passaram a apresentar esta distribuição normal conforme o teste efetuado, e os valores para $\mathrm{W}$ foram de 0,97 para todos os intervalos de profundidade.

Foi necessário um segundo raleio dos dados de 0,30 a 0,35 m para que apresentassem distribuição normal, com valor $W$ de 0,96 , sendo que para a profundidade máxima, de 0,35 a 0,40 m, o raleio foi efetuado sem eficácia, e os dados somente apresentaram distribuição normal depois de tratados com a transformação pela raiz quadrada, apresentando, neste caso, valor $\mathrm{W}$ igual a 0,96 . Os dados do IC na faixa de profundidade de 0,20 a $0,40 \mathrm{~m}$ também não tinham apresentado inicialmente distribuição normal, e alcançaram esta distribuição após a retirada dos dados candidatos a discrepantes e a transformação dos mesmos por meio do logaritmo na base 10, apresentando então o valor para W de 0,99. 
Tabela 7. Parâmetros da estatística descritiva referentes ao IC, teor de água, teor de matéria orgânica, teor de argila, densidade e espaço poroso do solo para a área 3

\begin{tabular}{|c|c|c|c|c|c|c|c|}
\hline $\begin{array}{l}\text { Profundidade } \\
\text { (m) }\end{array}$ & Média & Mínimo & Máximo & Variância & $\begin{array}{l}\text { Desvio } \\
\text { Padrão }\end{array}$ & $\begin{array}{l}\text { Coef. de } \\
\text { variação }\end{array}$ & $W^{*}$ \\
\hline \multicolumn{8}{|c|}{ IC (MPa) } \\
\hline 0,00 a 0,05 & 1,13 & 0,39 & 2,29 & 0,15 & 0,39 & 34,51 & $0,98^{* *}$ \\
\hline 0,05 a 0,10 & 2,12 & 0,42 & 4,47 & 0,47 & 0,68 & 32,08 & $0,98^{* *}$ \\
\hline 0,10 a 0,15 & 2,28 & 0,51 & 4,68 & 0,65 & 0,81 & 35,53 & $0,97^{* *}$ \\
\hline 0,15 a 0,20 & 2,21 & 0,74 & 6,09 & 0,73 & 0,85 & 38,46 & 0,93 \\
\hline 0,20 a 0,25 & 2,17 & 0,82 & 6,22 & 0,58 & 0,76 & 35,02 & 0,92 \\
\hline 0,25 a 0,30 & 2,13 & 0,71 & 6,95 & 0,50 & 0,71 & 33,33 & 0,83 \\
\hline 0,30 a 0,35 & 2,06 & 0,38 & 7,70 & 0,52 & 0,72 & 34,95 & 0,71 \\
\hline 0,35 a 0,40 & 2,09 & 0,75 & 7,31 & 0,67 & 0,82 & 39,23 & 0,64 \\
\hline 0,00 a 0,20 & 1,93 & 0,57 & 3,71 & 0,33 & 0,57 & 29,53 & $0,97^{* *}$ \\
\hline 0,20 a 0,40 & 2,11 & 1,17 & 6,45 & 0,40 & 0,63 & 29,86 & 0,78 \\
\hline \multicolumn{8}{|c|}{ Teor de água (\%) } \\
\hline 0,00 a 0,20 & 15,87 & 9,21 & 27,94 & 22,69 & 4,76 & 29,99 & 0,92 \\
\hline 0,20 a 0,40 & 16,40 & 10,48 & 27,70 & 20,70 & 4,55 & 27,74 & 0,90 \\
\hline \multicolumn{8}{|c|}{ Teor de matéria orgânica $\left(\mathrm{g} / \mathrm{dm}^{3}\right)$} \\
\hline 0,00 a 0,20 & 23,86 & 14,00 & 40,00 & 59,20 & 7,69 & 32,23 & 0,91 \\
\hline \multicolumn{8}{|c|}{ Teor de argila (\%) } \\
\hline 0,00 a 0,20 & 21,50 & 11,50 & 42,30 & 83,39 & 9,13 & 42,47 & 0,86 \\
\hline \multicolumn{8}{|c|}{ Teor de silte $(\%)$} \\
\hline \multicolumn{8}{|c|}{ Densidade do solo $\left(\mathrm{g} / \mathrm{cm}^{3}\right)$} \\
\hline 0,15 a 0,18 & 1,34 & 0,98 & 1,70 & $2,90 \times 10^{-2}$ & 0,17 & 12,69 & $0,98^{* *}$ \\
\hline \multicolumn{8}{|c|}{ Espaço poroso (\%) } \\
\hline$\underline{0,15}$ a 0,18 & 44,98 & 28,44 & 59,56 & 56,74 & 7,53 & 16,74 & $0,98^{* *}$ \\
\hline
\end{tabular}

Apesar de não apresentar candidatos a discrepantes, a população de dados do teor de água não resultou em distribuição normal em nenhuma das 
duas profundidades estudadas. Em decorrência disto, após a aplicação da transformação pelo logaritmo na base 10 conseguiu-se a distribuição normal para a profundidade de 0,00 a $0,20 \mathrm{~m}$, com $\mathrm{W}$ de 0,96 . Para os dados referentes ao teor de água na profundidade de 0,20 a 0,40 m, mesmo após inúmeras transformações dos dados, não obteve-se distribuição normal. Os dados relacionados ao teor de silte somente apresentaram distribuição normal após a retirada dos canditados a discrepantes e a transformação dos dados através do logaritmo na base 10. Para os dados do teor de matéria orgânica e de argila não foi possível a obtenção de distribuição normal, mesmo com tentativas de diversas transformações.

Com as transformações efetuadas foi possível a análise através da geoestatística e a aquisição dos parâmetros do semivariograma ajustado aos dados que apresentaram distribuição normal. $O$ resultado desta análise geo-estatística é apresentado na Tabela 8.

Os dados de IC nas profundidades de 0,20 a 0,25 m, teor de água de 0,00 a 0,20 m e densidade do solo de 0,15 a $0,20 \mathrm{~m}$ apresentaram dependência espacial forte e os demais dados apresentaram dependência espacial moderada segundo os preceitos de Cambardella et al. (1994). O valor do alcance dos atributos em geral foram maiores do que a distância entre as amostras. Constata-se com isto que as amostragens foram suficientes para detectar a dependência espacial existente. 
Tabela 8. Parâmetros relativos ao ajuste do semivariograma para o IC, teor de água densidade e espaço poroso do solo para a área 3

\begin{tabular}{|c|c|c|c|c|c|c|}
\hline $\begin{array}{l}\text { Profundidade } \\
\text { (m) }\end{array}$ & $\begin{array}{l}\text { Efeito } \\
\text { pepita } \\
\text { (CO) }\end{array}$ & $\begin{array}{l}\text { Patamar } \\
(\mathrm{CO}+\mathrm{C} 1)\end{array}$ & $\begin{array}{c}\text { Alcance } \\
(\mathrm{m})\end{array}$ & Função & $\frac{\mathrm{Co} \times 100}{\mathrm{Co}+\mathrm{C} 1}$ & Observação \\
\hline \multicolumn{7}{|c|}{ IC } \\
\hline 0,00 a 0,05 & & . & & .. & .. & Modelo sem patamar \\
\hline 0,05 a 0,10 & 0,19 & 0,35 & 505,80 & Exponencial & 54,29 & \\
\hline 0,10 a 0,15 & 0,30 & 0,54 & 213,60 & Exponencial & 55,55 & \\
\hline 0,15 a 0,20 & 0,20 & 0,39 & 42,80 & Exponencial & 51,28 & \\
\hline 0,20 a 0,25 & 0,08 & 0,35 & 41,27 & Exponencial & 22,86 & \\
\hline 0,25 a 0,30 & 0,08 & 0,25 & 48,04 & Exponencial & 32,00 & \\
\hline 0,30 a 0,35 & .. & .. & .. & .. &.. & Modelo sem patamar \\
\hline 0,35 a 0,40 & $1,1 \times 10^{-2}$ & $1,7 \times 10^{-2}$ & 73,4 & Exponencial & 64,71 & \\
\hline 0,00 a 0,20 & 0,16 & 0,25 & 81,48 & Exponencial & 64,00 & \\
\hline 0,20 a 0,40 & $4,2 \times 10^{-3}$ & $8,8 \times 10^{-3}$ & 174,00 & $\begin{array}{l}\text { Esférico } \\
\text { Teor de água }\end{array}$ & 47,73 & \\
\hline 0,00 a 0,20 & $3,0 \times 10^{-3}$ & $12,5 \times 10^{-3}$ & ${ }^{148,6}$ & $\begin{array}{l}\text { Exponencial } \\
\text { ensidade do so }\end{array}$ & 24,00 & \\
\hline 0,15 a 0,20 & \multicolumn{6}{|c|}{ Espaço Poroso } \\
\hline 0,15 a 0,18 & 38,55 & 59,55 & 291,90 & $\begin{array}{c}\text { Esférico } \\
\text { Teor de silte }\end{array}$ & 64,73 & \\
\hline
\end{tabular}


O alcance do IC nas profundidades de 0,00 a 0,05 e 0,30 a $0,35 \mathrm{~m}$ e do teor de silte na profundidade de 0,00 a 0,20 m não puderam ser determinados com a quantidade de amostras coletadas em campo, uma vez que estes modelos não atingiram seu patamar, fornecendo por este motivo, dados insuficientes para a interpolação por krigagem. Contudo, para estes dados também detectou-se dependência espacial, o que também demonstra a suficiência da amostragem efetuada para se determinar o modelo em ambos. Esses parâmetros foram interpolados pelo método do inverso da distância.

O mesmo interpolador também foi utilizado para se proceder a interpolação dos dados que não apresentaram distribuição normal, ou seja, teor de água de 0,20 a 0,40 m, teor de argila e de matéria orgânica na mesma profundidade. O resultado gráfico dos mapas gerados por interpolação é apresentado na Figura 4.

A faixa de profundidade com o IC mais elevado nesta área distribui-se da profundidade de 0,05 a $0,20 \mathrm{~m}$, somente sobre a região mais arenosa do solo. Isso coincide com o observado nas demais áreas, com um IC mais elevado nas menores profundidades. Contudo, para este caso particular, a profundidade com maiores valores de IC foi de 0,10 a $0,15 \mathrm{~m}$ na região sudeste do talhão, onde o solo tem menos teor de argila e de matéria orgânica, existindo também na faixa limítrofe do talhão, a sudoeste, uma região que apresentou valor do IC maior à profundidade de 0,35 a 0,40 . Esta região encontra-se em cota de altitude inferior no terreno, próxima à calha de um ribeirão, o qual flui sobre o um leito rochoso, indicando a pequena profundidade do solo nas proximidades. Este fato pode ter influenciado o resultado, quando a haste do penetrômetro interceptou o terreno com maior quantidade de cascalho, onde a quantidade de obstáculos à penetração do solo é maior. 

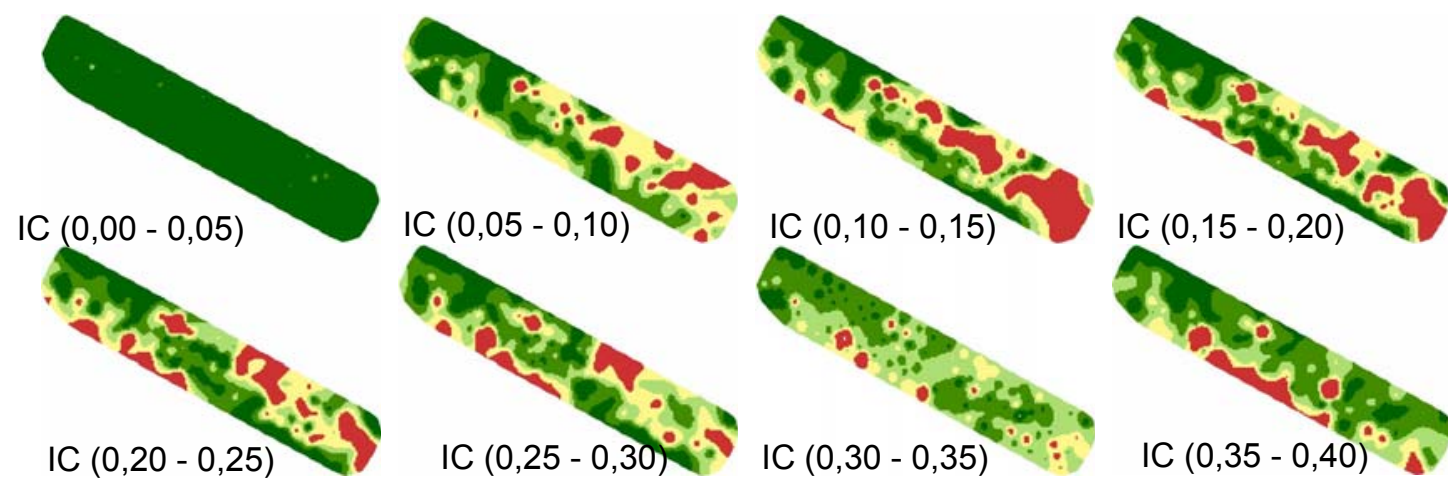

IC $(0,20-0,25)$
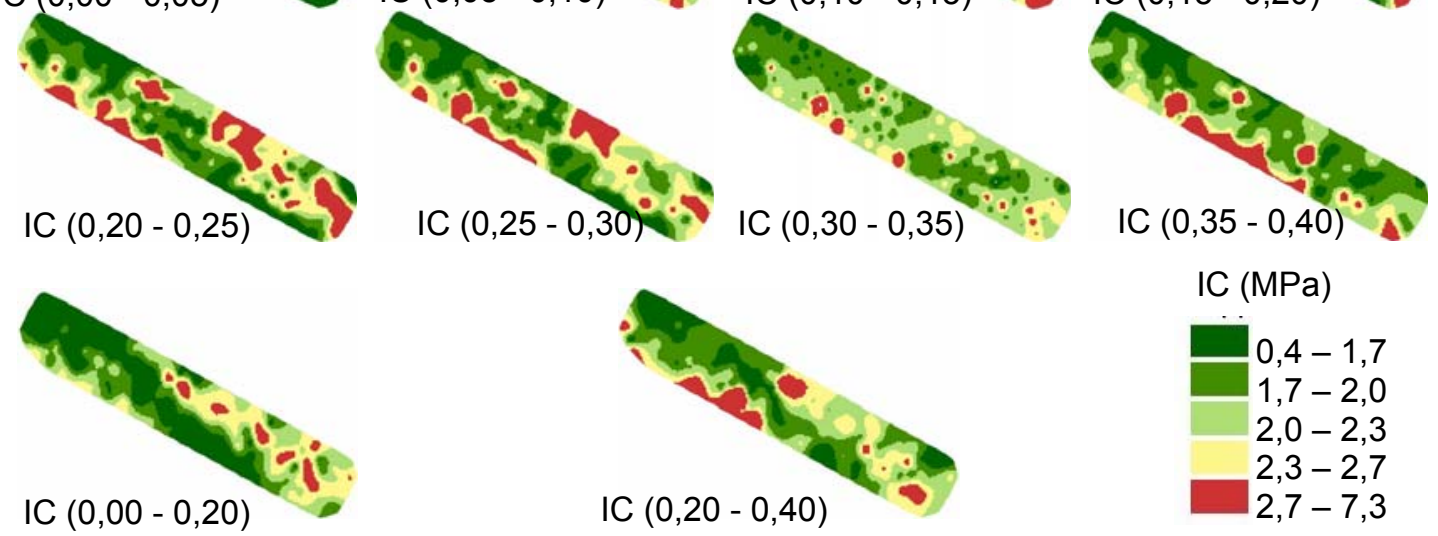

IC (MPa)
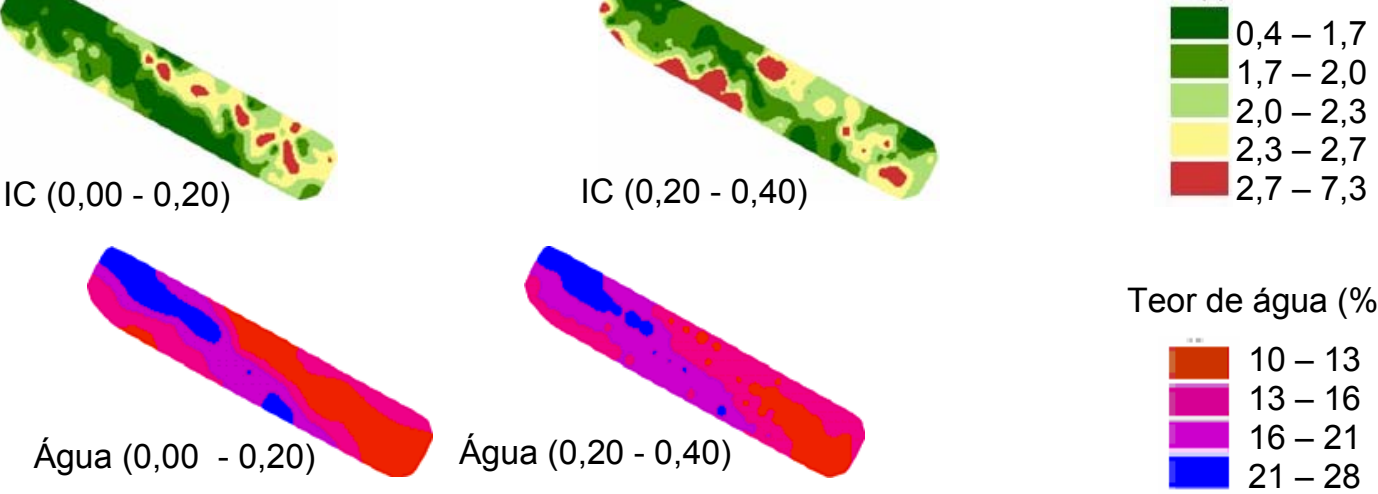

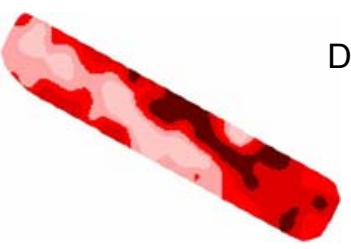

Densidade $(0,15-0,18)$

Densidade $\left(\mathrm{g} / \mathrm{cm}^{3}\right)$
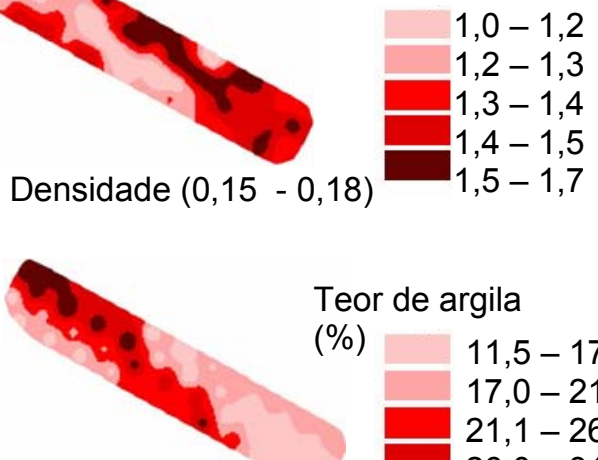

Teor de argila

(\%)

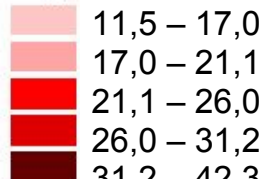

Argila $(0,00-0,20)$ $31,2-42,3$

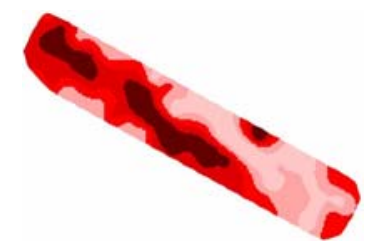

Espaço poroso $(0,15-0,18)$

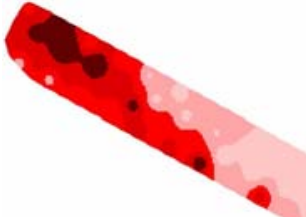

Silte $(0,00-0,20)$

Teor de matéria orgânica $14,9-19,6$ $19,6-23,4$ $23,4-27,7$ $27,7-32,1$ $32,1-40,0$ เ61:
Teor de água (\%)

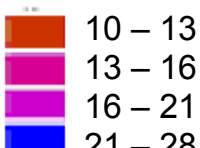

Espaço poroso (\%) $28,9-38,7$ $38,7-42,3$ $42,3-46,3$ $46,3-50,1$ $50,1-59,5$

Teor de silte

(\%)
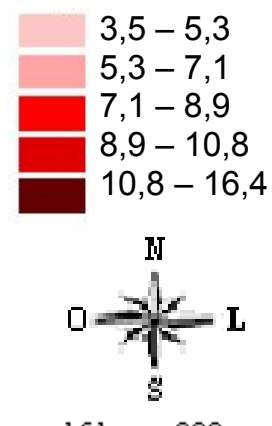

Matéria Orgânica $(0,00-0,20)$

$\left(\mathrm{g} / \mathrm{dm}^{3}\right)$

61

o $161 \quad 322 \mathrm{~m}$

Figura 4 - Mapas dos atributos IC, teor de água, teor de matéria orgânica, teor de argila, densidade e espaço poroso do solo, estudados na área 3 
Pela análise visual dos mapas gerados observa-se, mais nitidamente do que nos demais casos, uma relação inversamente proporcional entre teor de água e IC. A noroeste do talhão, onde há mais teor de água, o IC apresentou valores menores, e a sudeste do talhão, onde o teor de água foi menor, este índice foi mais elevado.

Há também outras correlações visivelmente constatadas entre o IC e demais atributos, como teor de argila, teor de matéria orgânica, teor de silte, densidade e porosidade do solo. Ainda observa-se uma mancha nítida de menor IC à noroeste do talhão, a qual é coincidente com a área de maior teor de argila e silte e com o local onde há maior teor de água.

Os solos mais argilosos têm maior capacidade de armazenamento de água quando comparados aos mais arenosos (Brady \& Weil, 2001; Teixeira et al., 2000). Esta situação pode ter proporcionado maior quantidade de água neste local, suficiente para a diminuição da resistência à penetração, proporcionando menores valores para o IC.

Segundo Brady \& Weil (2001), solos mais argilosos são mais susceptíveis à compactação, mas os mesmos autores também identificam a função da matéria orgânica do solo como fator no mantimento da sua estrutura física e vida biológica. Esta matéria orgânica também presta-se para diminuir o potencial de compactação dos solos, mantendo a sua distribuição de poros e conferindo menor densidade.

Ainda, com relação à mancha a noroeste do talhão, observa-se uma menor densidade do solo e maior porcentagem de espaço poroso neste local, o que indica uma menor compactação do solo. A mesma área apresenta maior teor de argila, mas em contrapartida, também apresenta o teor de matéria orgânica superior aos outros locais amostrados, o que pode ter diminuído o seu potencial de compactação.

A correlação visual entre o teor de argila, silte e matéria orgânica pode estar associada à desaceleração do processo de decomposição da matéria orgânica em locais com solo mais argiloso, uma vez que as partículas de 
matéria orgânica com tamanho coloidal podem ficar armazenadas entre as placas de argila (Brady \& Weil, 2001). Neste caso, há indícios de que a matéria orgânica foi estabilizada pela associação com argila e silte, uma vez que, segundo Six et al. (2002), a interação desta matéria orgânica com silte e argila promove a formação de macroagregados (argilo-minerais) cimentados por interações eletro estáticas entre Fe (III), óxidos de alumínio e suas hidroxilas. Tais relações puderam ser constatadas através da regressão e os resultados são apresentados na Tabela 9.

No caso do teor de água relacionado com o IC, o modelo ajustado aos dados para as faixas de profundidades de 0,00 a $0,20 \mathrm{~m}$ e 0,00 a $0,40 \mathrm{~m}$, demonstra existir relação inversa entre estes dois fatores, ou seja, quando o teor de água aumenta o IC decresce, tendendo à estabilização. Entre o teor de água e o IC, o melhor ajuste do modelo ocorreu na camada mais superficial ( 0,0 a $0,2 \mathrm{~m})$, uma vez que nesta profundidade o modelo foi suficiente para explicar $62 \%$ da variabilidade dos dados, enquanto que na profundidade de 0,2 a $0,4 \mathrm{~m}$, o modelo foi suficiente para explicar apenas $24 \%$. Na profundidade de 0,0 a 0,2 m há maior teor de água na porção a noroeste do talhão e menor na região a sudeste deste quando comparada à profundidade de 0,2 a 0,4 m.

A não linearidade nos efeitos do teor de água à resistência a penetração dos solos, defendida por Henderson et al. (1988), pode ter influenciado na deficiência ao ajuste do modelo encontrada na área 1 quando comparada às demais áreas, pois os teores de água nesta área foram maiores do que nas demais, e os valores de IC também foram inferiores a aqueles mensurados nos outros dois locais de estudo. No caso particular da área 3, em comparação com as demais áreas, um melhor ajuste do modelo entre o teor de água e o IC também pode ter sido influenciado por outros fatores, os quais disciplinaram o teor de água do solo a certas manchas, uma vez que obseva-se maior relação entre teor de água, argila, silte, teor de matéria orgânica e IC. 
Tabela 9. Regressão entre os dados interpolados dos parâmetros estudados na área 3

\begin{tabular}{|c|c|c|c|}
\hline Variável $\mathrm{x}$ & Variável y & Fórmula & $\mathrm{R}^{2}$ \\
\hline \multicolumn{4}{|c|}{ Profundidade de 0,00 a $0,20 \mathrm{~m}$} \\
\hline Teor de água & IC & $Y=3,8079 e^{-0,0446 x}$ & 0,62 \\
\hline Teor de argila & IC & $Y=3,6023 e^{-0,0303 x}$ & 0,57 \\
\hline Teor de silte & IC & $Y=3,1655 e^{-0,0697 x}$ & 0,49 \\
\hline $\begin{array}{l}\text { Teor de matéria } \\
\text { oraânica }\end{array}$ & IC & $Y=3,916 e^{-0,0309 x}$ & 0,53 \\
\hline Teor de argila & Teor de água & $\begin{array}{c}Y=-0,0085 x^{2}+1,0605 x- \\
2,693\end{array}$ & 0,85 \\
\hline Teor de silte & Teor de água & $Y=1,4656 x+4,8746$ & 0,69 \\
\hline $\begin{array}{l}\text { Teor de matéria } \\
\text { oraânica }\end{array}$ & Teor de água & $Y=0,6576 x+0,1958$ & 0,77 \\
\hline Teor de argila & $\begin{array}{l}\text { Teor de matéria } \\
\text { orgânica }\end{array}$ & $\begin{array}{c}Y=-0,019 x^{2}+1,7767 x- \\
4,8606\end{array}$ & 0,85 \\
\hline Teor de silte & $\begin{array}{l}\text { Teor de matéria } \\
\text { orgânica }\end{array}$ & $Y=2,1245 x+7,8958$ & 0,82 \\
\hline \multicolumn{4}{|c|}{ Profundidade de 0,20 a $0,40 \mathrm{~m}$} \\
\hline Teor de água & IC & $3,4405 \mathrm{e}^{-0,0309 x}$ & 0,24 \\
\hline \multicolumn{4}{|c|}{ Profundidade de 0,15 a 0,20 m } \\
\hline Densidade & IC & $Y=1,6826 x-0,0892$ & 0,12 \\
\hline Espaço poroso & IC & $0,0009 x^{2}-0,1202 x+5,7518$ & 0,14 \\
\hline Densidade & Espaço poroso & $Y=-43,711 x+103,71$ & 0,96 \\
\hline \multicolumn{4}{|c|}{ Profundidade de 0,00 a 0,20 m a variável "x" e 0,15 a 0,20 m a variável "y" } \\
\hline Teor da argila & Densidade & $Y=2,8924 x^{-0,2536}$ & 0,44 \\
\hline Teor de silte & Densidade & $0,0023 x^{2}-0,0728 x+1,7501$ & 0,42 \\
\hline Teor de argila & Espaço poroso & $\begin{array}{c}Y=-0,0366 x^{2}+2,4198 x \\
+11,025\end{array}$ & 0,50 \\
\hline Teor de silte & Espaço poroso & $\begin{array}{c}Y=-0,1047 x^{2}+3,3532 x \\
+26,154\end{array}$ & 0,47 \\
\hline $\begin{array}{l}\text { Teor de matéria } \\
\text { orgânica }\end{array}$ & Densidade & $Y=0,0008 x^{2}-0,054 x+2,178$ & 0,47 \\
\hline $\begin{array}{l}\text { Teor de matéria } \\
\text { orgânica }\end{array}$ & Porosidade & $Y=12,354 x^{0,4069}$ & 0,50 \\
\hline
\end{tabular}


Essa situação pode ser devido à capacidade da matéria orgânica e argila em armazenarem água, (Brady \& Weil, 2001). Esse fato é observado pelos bons ajustes entre estes atributos, uma vez que o modelo ajustado entre o teor de matéria orgânica e o teor de água foi suficiente para explicar $77 \%$ da variabilidade dos dados e entre o teor de argila e o teor de água, com $85 \%$. 0 comportamento destes modelos ajustados, em ambos os casos, evidencia uma relação diretamente proporcional, ou seja, o aumento dos teores de argila e matéria orgânica resultam em maiores teores de água no solo, em uma função que tende levemente à estabilização no primeiro caso e em um comportamento linear no segundo.

Por outro lado solos com maior teor de argila e matéria orgânica tendem a apresentar também valores maiores para a capacidade de campo (Brady \& Weil, 2001), o que aumenta a quantidade de água necessária para se alcançar o teor citado por Henderson et al. (1988), de $70 \%$ da capacidade de campo, no qual a diminuição da água aumenta exponencialmente a sua influência na resistência à penetração do solo. Tal situação é um indicativo que não se pode tecer considerações conclusivas a respeito da menor influência no IC na região com maior teor de água, a qual também apresenta maior teor de argila e de matéria orgânica.

Em relação ao IC e o teor de argila e de matéria orgânica, obteve-se relações inversamente proporcionais, sendo estas coerentes no caso da relação com o teor de matéria orgânica, mas incoerentes, a primeira vista, em relação ao teor de argila.

A correlação negativa entre IC e o teor de argila identifica que a variação do IC, neste caso, é inversamente proporcional à variação do teor de argila em um modelo que tende à estabilização, e foi suficiente para explicar $57 \%$ da variabilidade dos dados. Esta situação, aparentemente incoerente, somente pode ser entendida quando o foco volta-se para a regressão entre os teores de argila e silte com o teor de matéria orgânica. Em ambos os casos esta foi diretamente proporcional e identificada por uma função que tende à 
estabilização no caso do teor de argila e com comportamento linear no caso do teor de silte.

O modelo ajustado para a relação entre o teor de argila com o teor de matéria orgânica foi suficiente para explicar $85 \%$ da variação dos dados, e em relação ao teor de silte e o teor de matéria orgânica, o modelo explica $82 \%$ desta variação. Os resultados evidenciam a existência de um maior teor de matéria orgânica nos locais com maior teor de argila e silte. Estes números apontam para a possível formação de macroagregados argilo-minerais, como sugerido por Six et al. (2002).

Como o teor de silte é mensurado por diferença, não cabem muitas considerações conclusivas a respeito de sua influência na formação de compostos argilo-minerais. Contudo, a delimitação da coincidência de maiores teores de silte e argila na mesma região do talhão é bastante notável.

Os resultados apontam que a situação de maior teor de matéria orgânica foi eficaz na manutenção da estrutura física do solo nos locais com maior teor de argila e silte, diminuindo o potencial de compactação pela manutenção de sua agregação e porcentagem de espaço poroso, situação esta já constatada anteriormente por Etana et al. (1997) e Assouline et al. (1997) em outras áreas.

Esse fato pode ser visualizado pela correlação existente entre o teor de matéria orgânica, densidade e porcentagem do espaço poroso do solo, ambos indicadores do seu grau de compactação. No caso da densidade do solo, a sua relação com a matéria orgânica demonstra um comportamento inversamente proporcional, ou seja, quanto maior o teor de matéria orgânica menor é a densidade do solo em uma função que explicou $47 \%$ da variabilidade dos dados e com tendência à estabilização da densidade do solo em baixos valores com o aumento da matéria orgânica. Em relação ao espaço poroso, a relação entre estes dois fatores foi proporcional, uma vez que o espaço poroso do solo cresce à medida que se aumenta o teor de matéria orgânica, e esse crescimento obedece a uma função suficiente para explicar $50 \%$ da variabilidade dos dados. 
Entre a densidade do solo e a sua porosidade total há uma forte relação, uma vez que um valor é função do outro em uma relação inversamente proporcional. Neste caso obteve-se um comportamento explicado por uma função linear, a qual foi suficiente para explicar $96 \%$ da variabilidade dos dados.

Pela regressão do espaço poroso e densidade com o teor de água do solo constatou-se um crescimento exponencial do teor de água com o aumento de poros e um decréscimo, também de forma exponencial, quando relacionada à densidade do solo. Os solos com maior porcentagem de espaço poroso e menor densidade apresentam maior espaço para o armazenamento de água.

Solos com maior espaço poroso são potencialmente melhor drenados (Teixeira et al., 2000). Na área 3 observou-se que as regiões com maior espaço poroso e menor densidade o teor de água aumentou sensivelmente. Esse comportamento, provavelmente é decorrente das interações do teor de argila, silte e matéria orgânica em relação ao espaço poroso. Este, como já discutido anteriormente, deve ter sido influenciado pelo teor de matéria orgânica no que diz respeito à conservação dos poros frente às pressões de compactação no campo. O crescimento exponencial do teor de água nos locais com maior porcentagem de espaço poroso certamente teve influência da existência de maiores teores de argila e matéria orgânica nestes locais, os quais aumentam a capacidade do solo em reter água (Brad \& Weil, 2001).

A regressão entre a densidade e espaço poroso do solo com o IC evidenciam que o aumento da densidade do solo causa um crescimento linear no IC, porém com um ajuste da função suficiente para explicar apenas $12 \%$ da variabilidade dos dados. O aumento do espaço poroso causa um decréscimo do IC, com uma função tendendo à estabilização e suficiente para explicar 14\% da variabilidade dos dados.

Devido às correlações entre densidade e porosidade do solo com o IC, constatou-se que os valores do IC foram eficazes para indicar a presença de compactação do solo, uma vez que a descrição da compactação por Seixas 
(1988) e Gupta \& Allmaras (1987), dentre outros, inclui a ocorrência do aumento da densidade e decréscimo no volume de poros, fatores que tiveram comportamento coerente com o IC. As correlações entre IC aferido por penetrometria e a compactação do solo já foram consideradas em inúmeros trabalhos (Seixas \& Junior, 2001; Santos, 1993; Klein, 1998; Bertol et al., 2001; Silva Junior, 2001; Abrão et al., 1978). Além da importância incontestável da influência no IC do teor de água, densidade e porosidado do solo, constatou-se que os teores de argila, silte e matéria orgânica apresentaram considerável interação com o IC. 


\section{CONCLUSÕES}

Por meio da mensuração do IC em grade amostral nas áreas estudadas, constatou-se a ocorrência de valores menos elevados nas menores profundidades. Esses valores foram maiores na profundidade de 0,10 a 0,15 m na área 1 e na profundidade de 0,10 a 0,20 e na área 2. Na área 3, ocorreu nas regiões com menor teor de argila e matéria orgânica nas profundidades de 0,10 a $0,15 \mathrm{~m}$.

A evidência da relação entre o teor de água do solo e o IC por meio de mapas interpolados nem sempre é possível, principalmente em situações em que o solo apresenta-se com elevado teor de água.

O teor de argila deve ser considerado em estudos sobre a resistência à penetração do solo uma vez que este atua disciplinando o teor de água, o qual tem bastante potencial em diminuir a resistência à penetração do solo, medida com penetrômetro.

A análise entre indicadores diretos e indiretos, tais como IC, umidade, densidade, espaço poroso, teores de argila, silte, matéria orgânica e outros é possível através da utilização de mapas interpolados destes atributos. As relações de causa e efeito observadas nos mapas de atributos físicos dos solos podem ser confirmadas por meio das regressões entre os dados interpolados que os compõem.

Há necessidade de estudos adicionais em relação à influência espacial do teor de argila e silte no que se refere à formação de compostos argilominerais e à diminuição do potencial de compactação dos solos com maiores teores dessas frações minerais em sistemas sob semeadura direta. 
ANEXOS 
51

ANEXO A. Semivariogramas da área 1
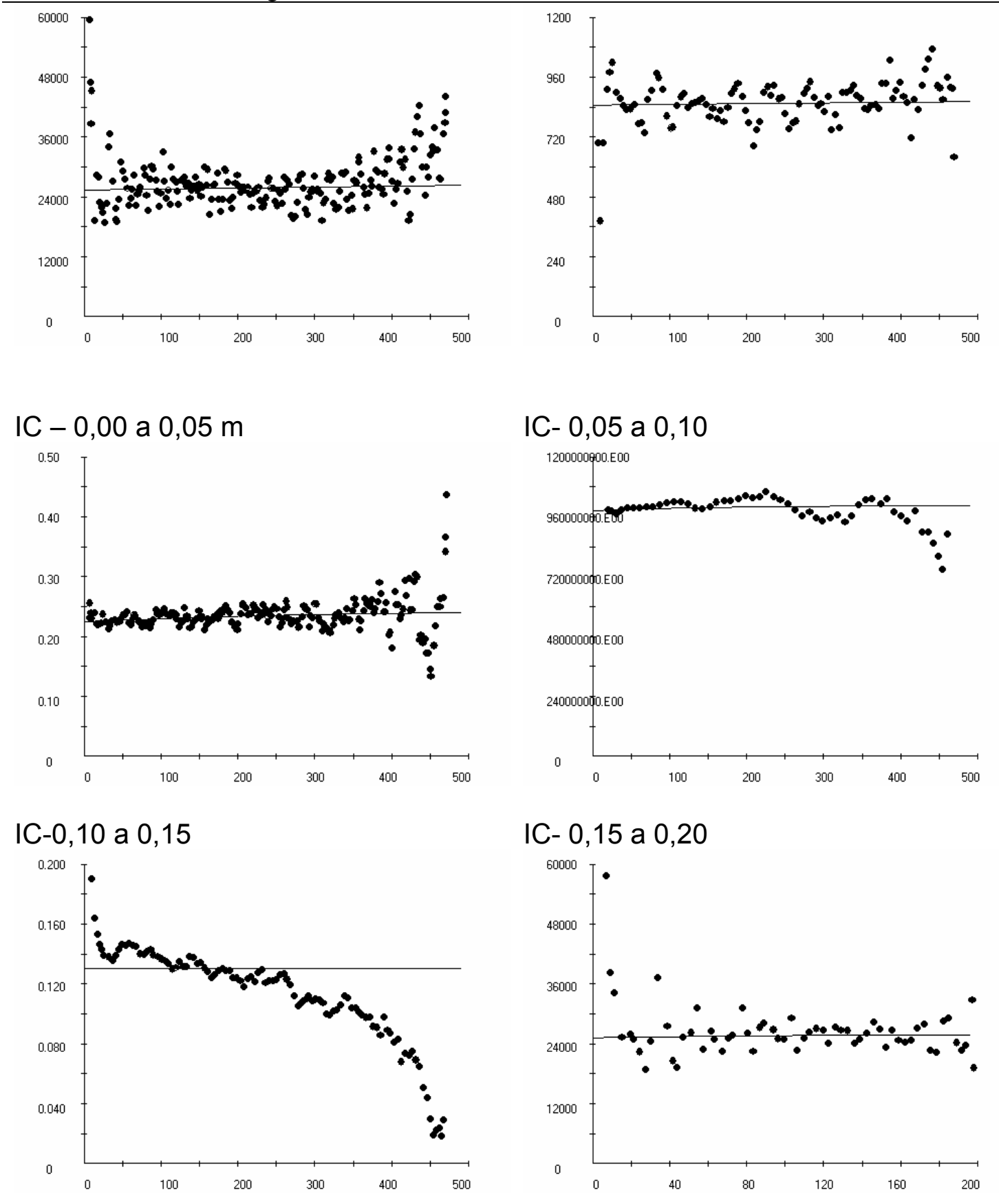

IC- 0,20 a 0,25

IC- 0,25 a 0,30 
ANEXO A- Semivariogramas da área 1

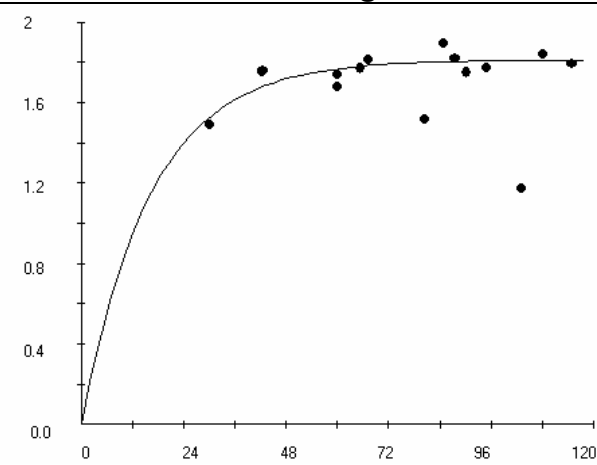

C- 0,30 a 0,35
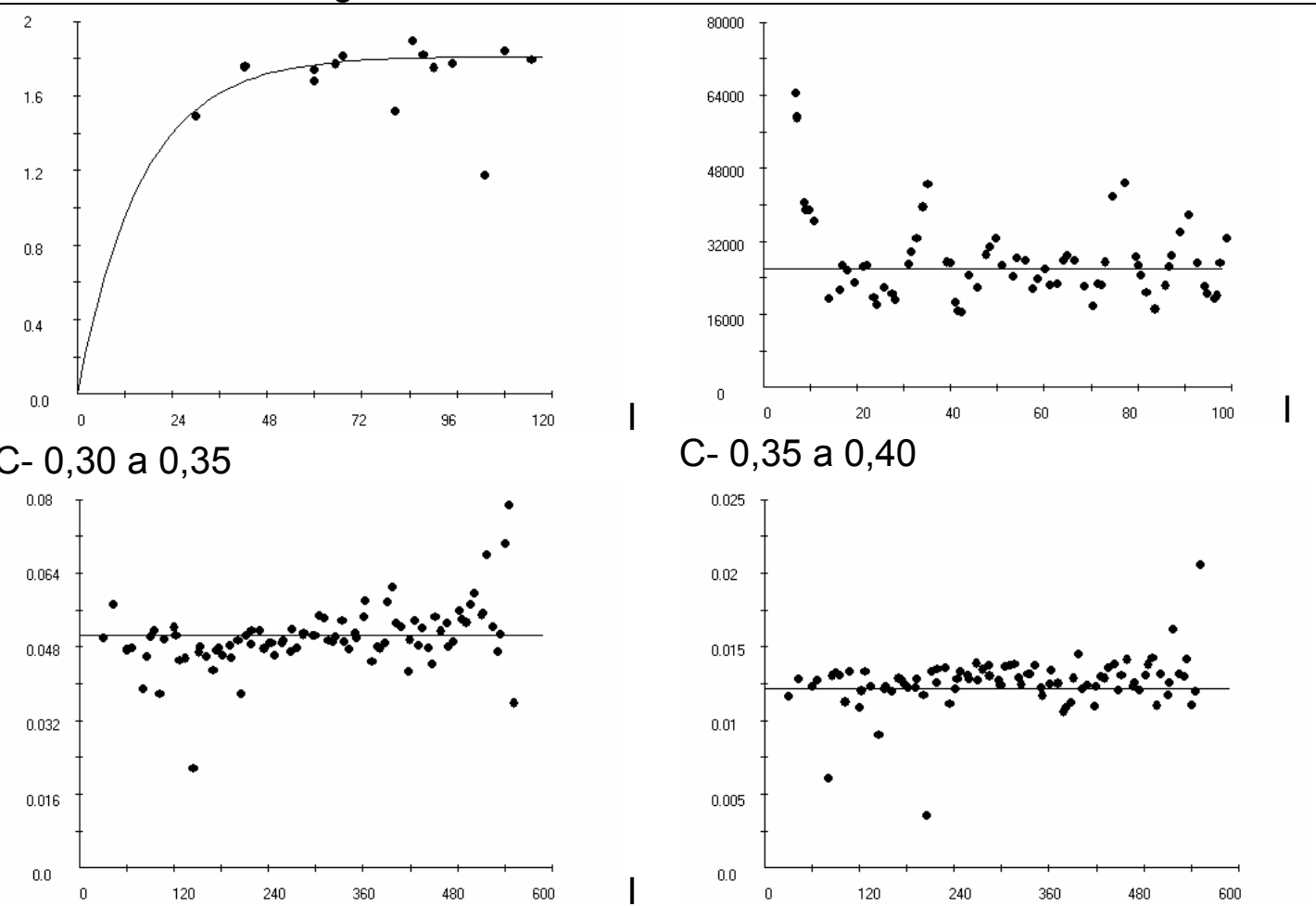

C- 0,00 a 0,20

C- 0,35 a 0,40

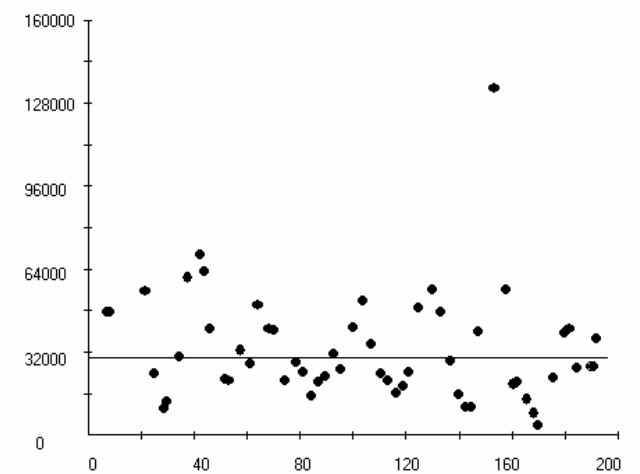

Umid- 0,00 a 0,20

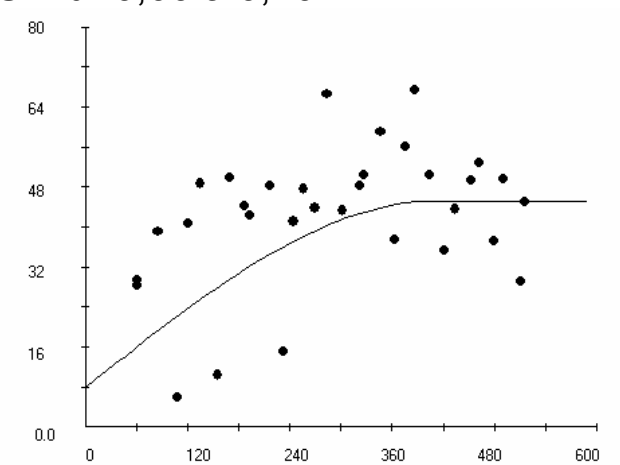

Teor argila- 0,00 a 0,20

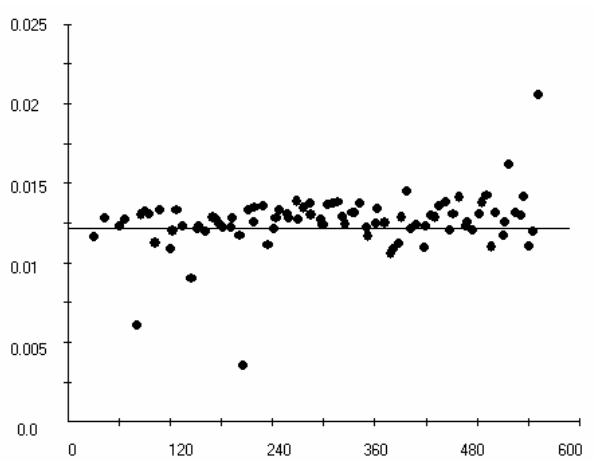

IC- 0,20 a 0,40

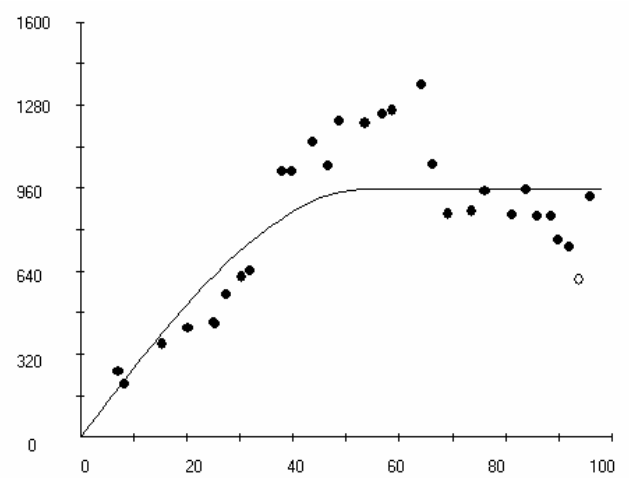

Umid- 0,20 a 0,40

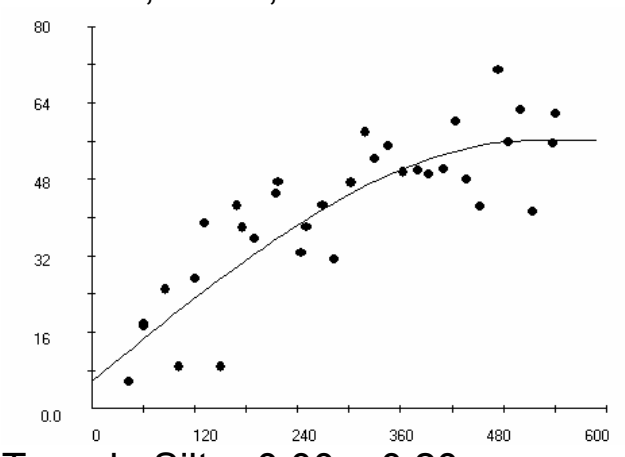

Teor de Silte- 0,00 a 0,20 
ANEXO B: Semivariogramas da área 2

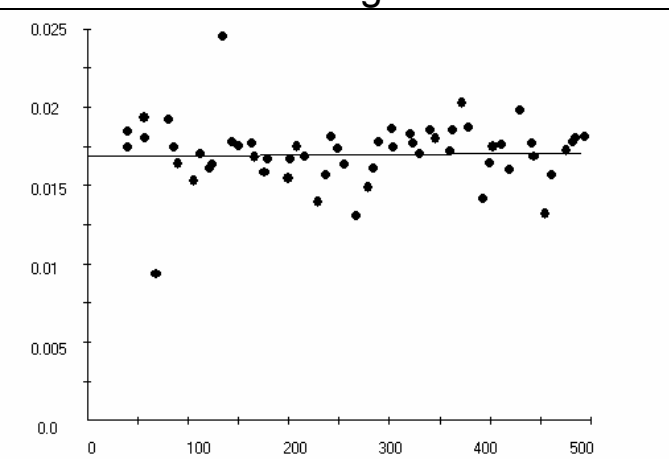

C- 0,00 a 0,05

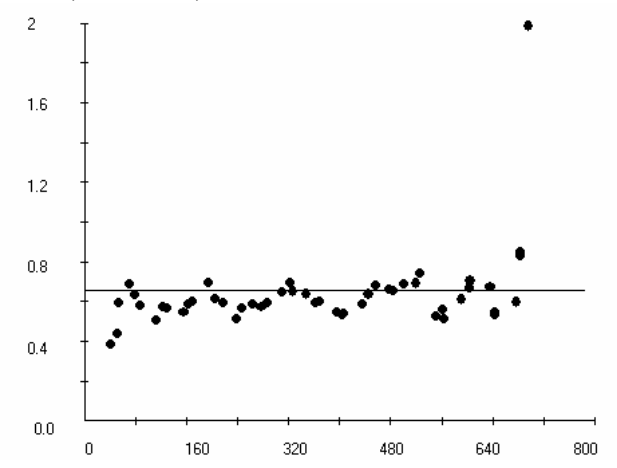

C- 0,10 a 0,15

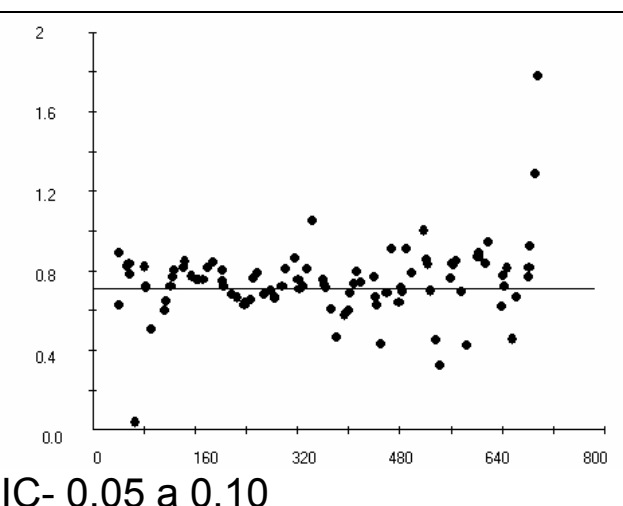
IC- 0,05 a 0,10

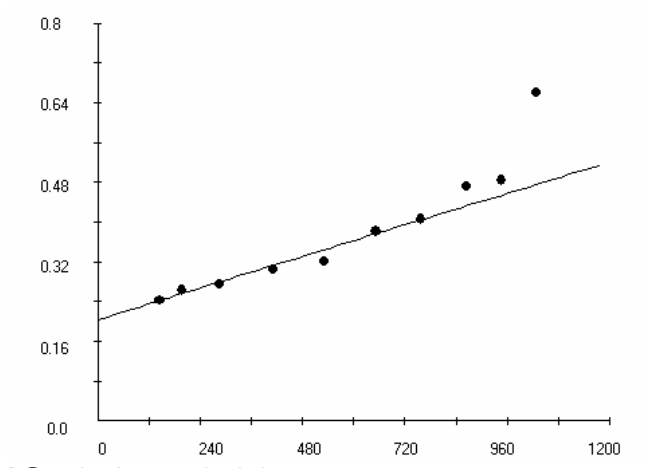

IC- 0,15 a 0,20

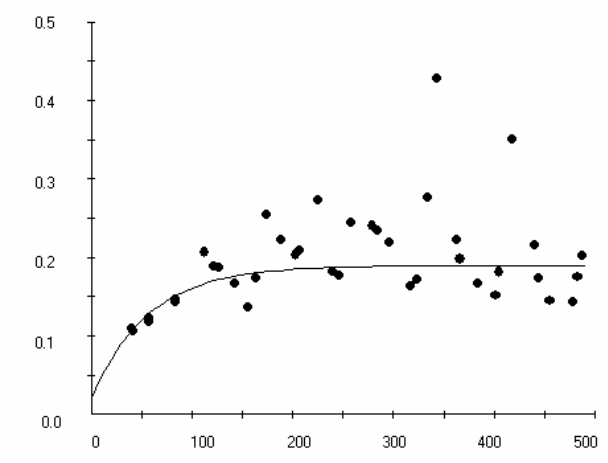

C- 0,20 a 0,25

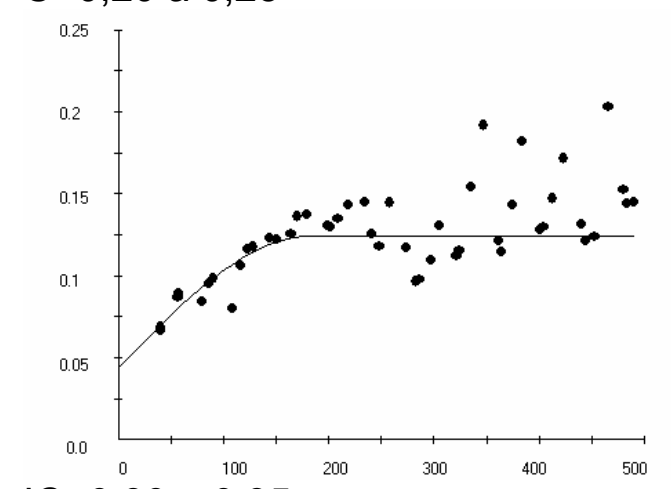

IC- 0,30 a 0,35

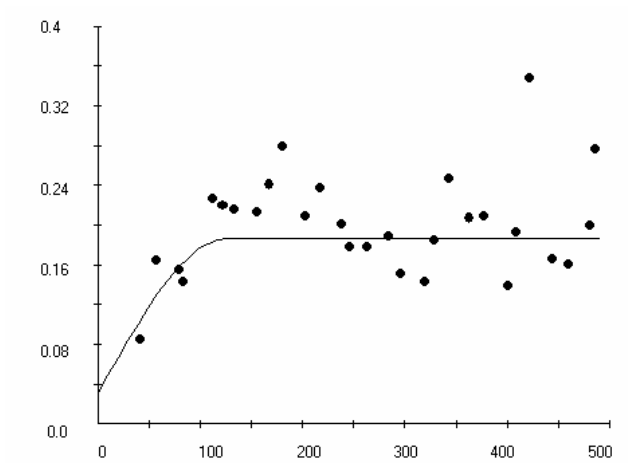

IC- 0,25 a 0,30

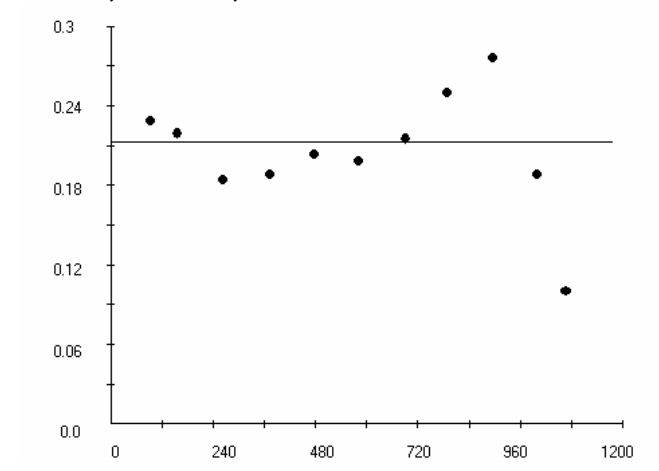

IC- 0,35 a 0,40 
ANEXO B- Semivariogramas da área 2
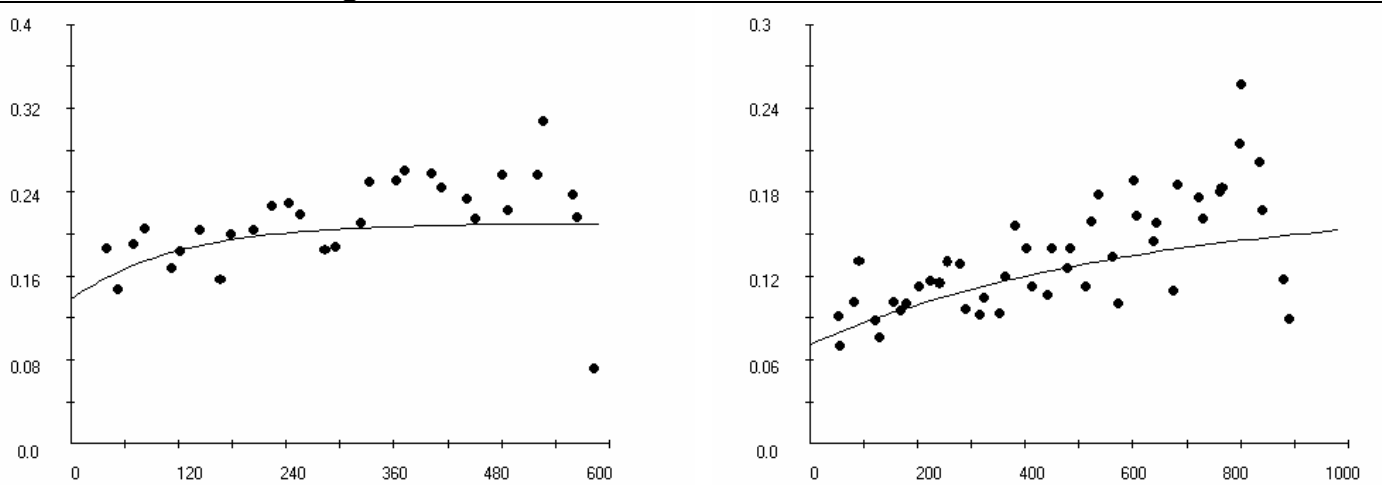

IC- 0,00 a 0,30

IC- 0,00 a 0,40
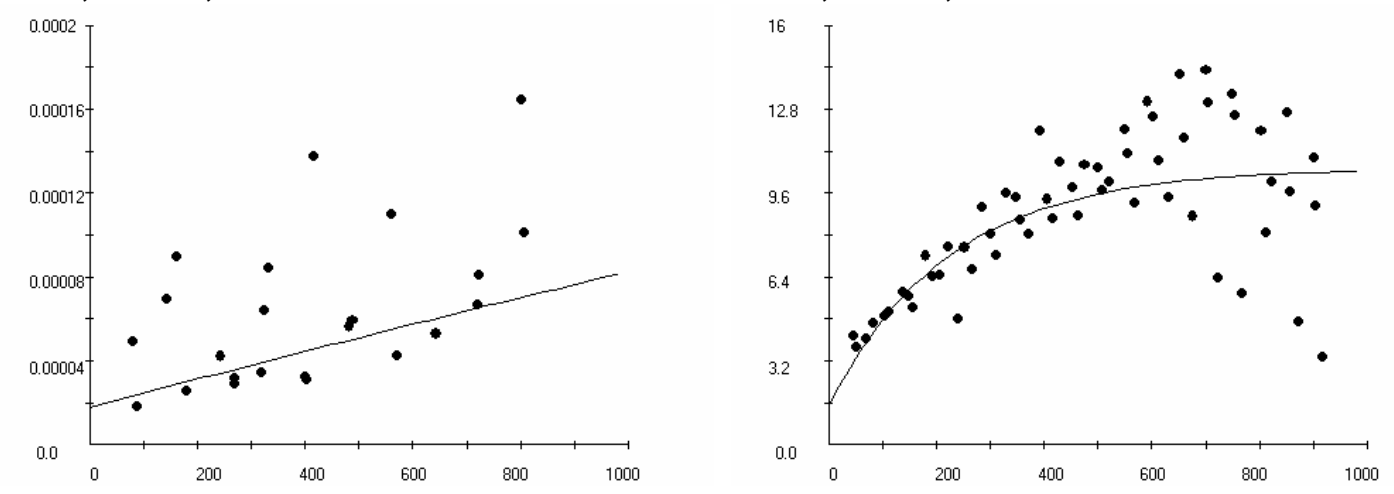

Teor de água 0,00 a 0,30

Teor de argila 0,00 a 0,40

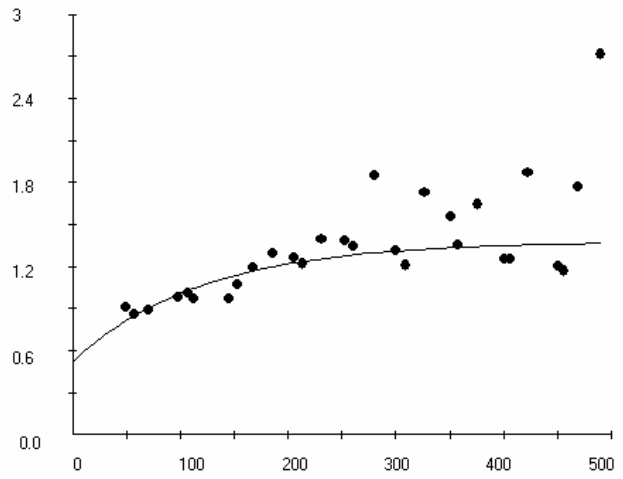

Teor de silte 0,00 a 0,40 
ANEXO C- Semivariogramas da área 3

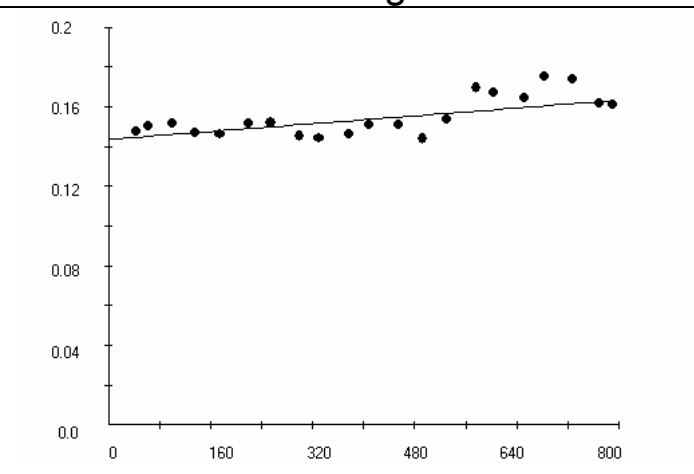

C- 0,00 a 0,05

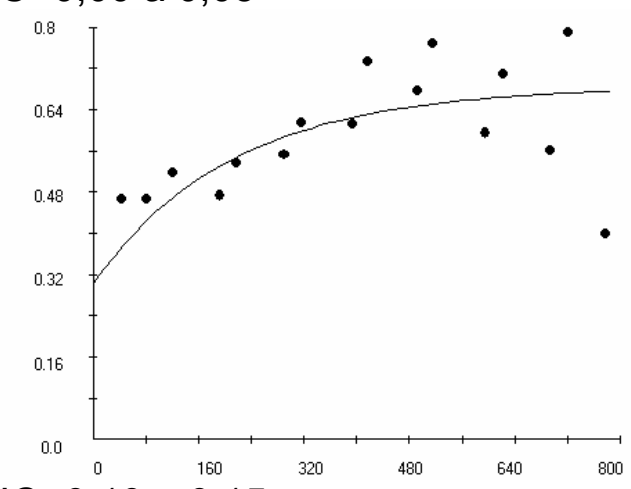

IC- 0,10 a 0,15
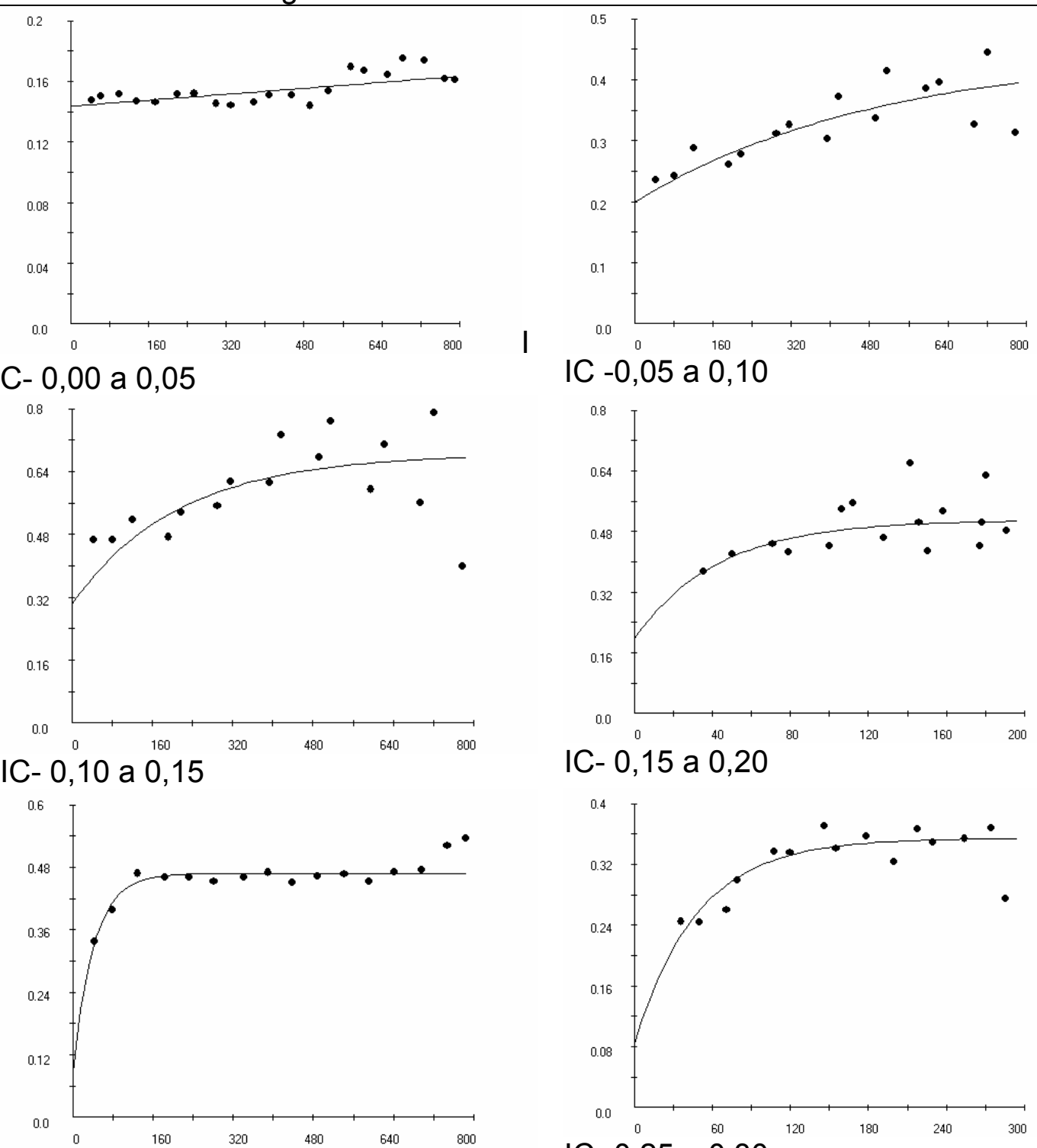

IC- 0,20 a 0,25

IC- 0,15 a 0,20

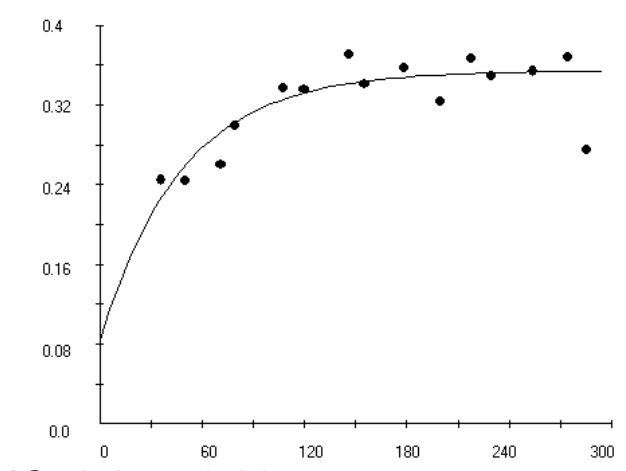

IC- 0,25 a 0,30
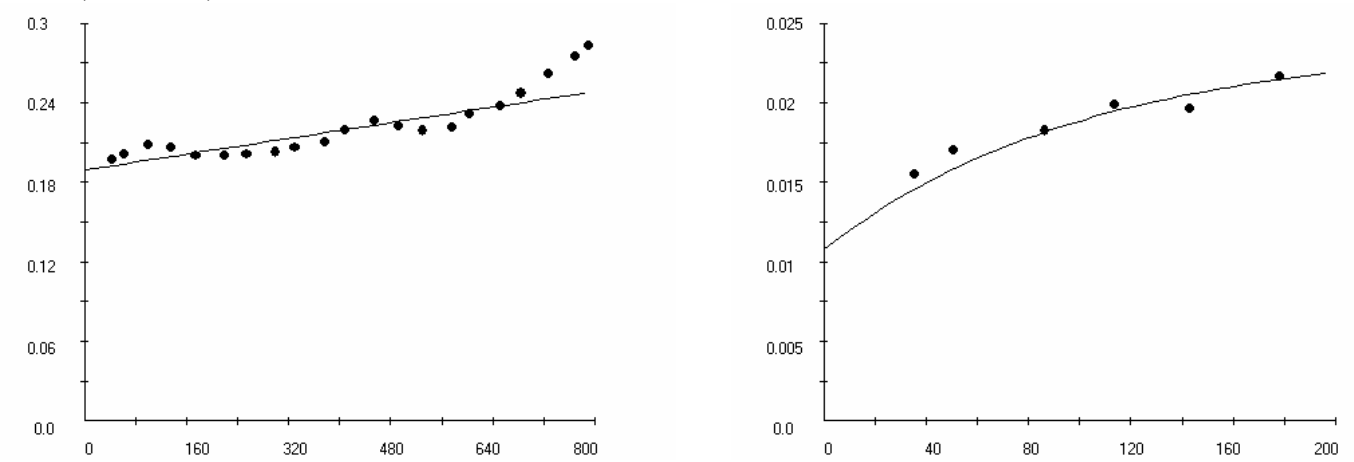
ANEXO C- Semivariograma da área 3.
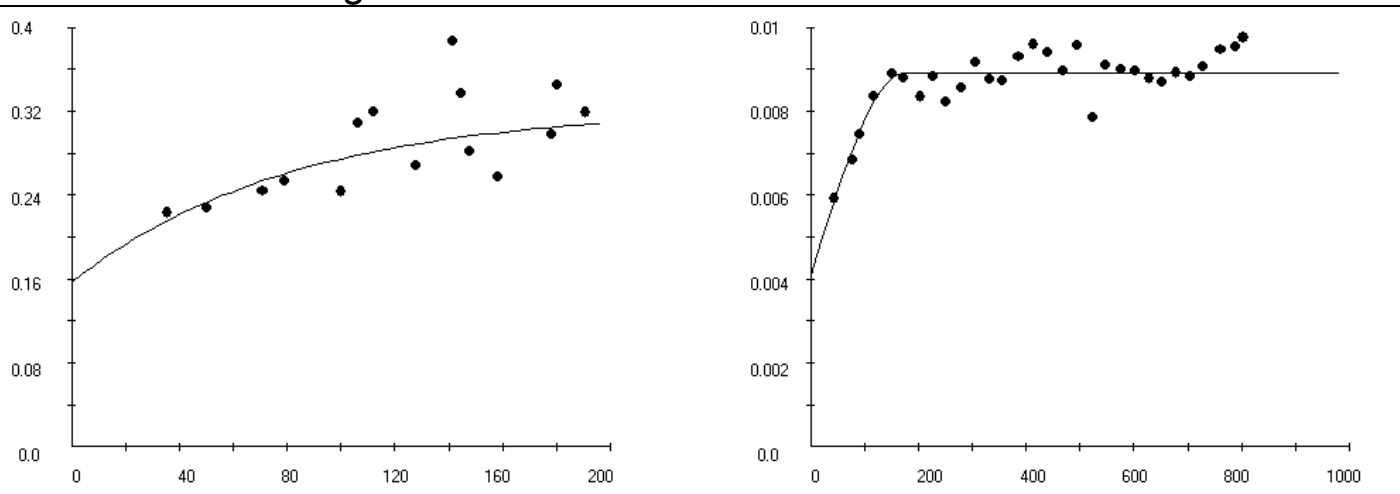

IC- 0,00 a 0,20

IC- 0,20 a 0,40

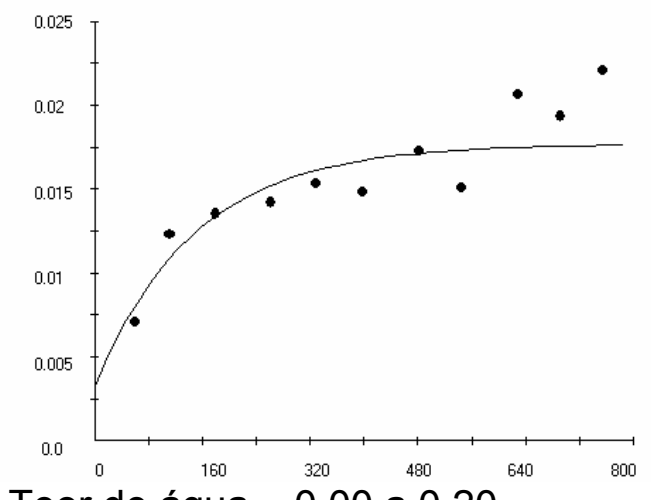

Teor de água - 0,00 a 0,20
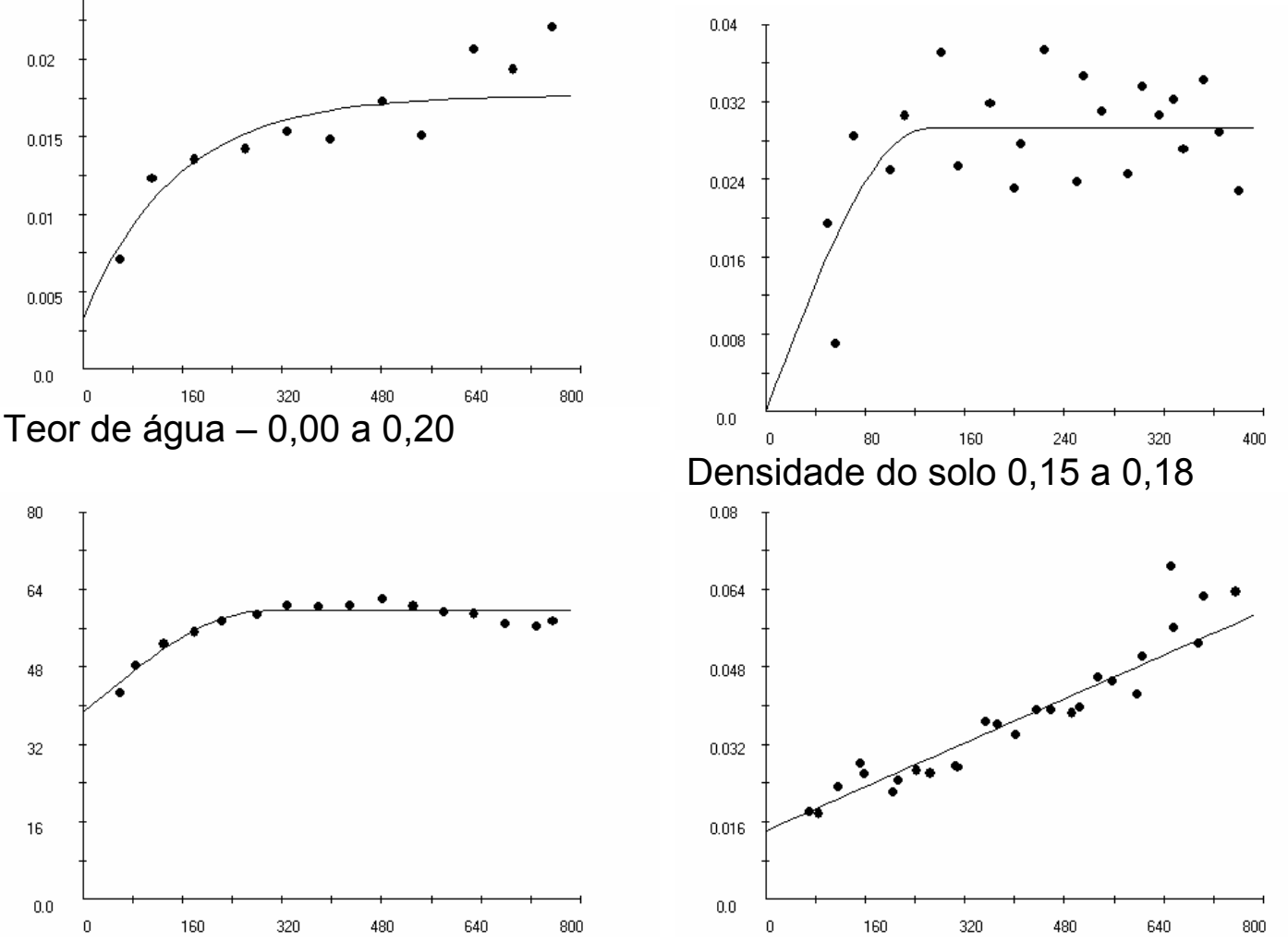

Densidade do solo 0,15 a 0,18

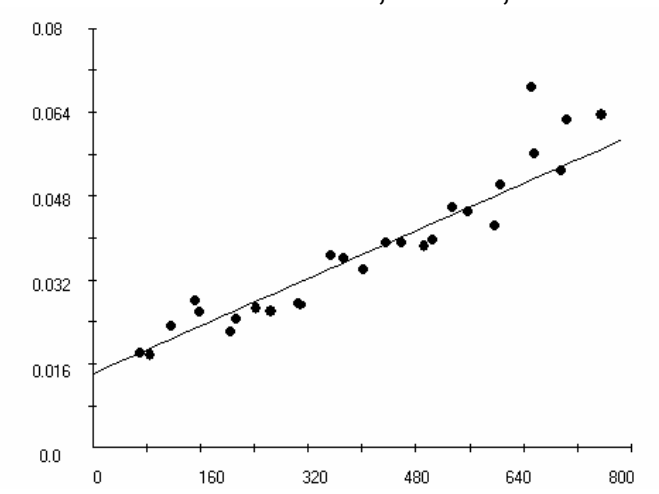

Espaço poroso do solo 0,15 a 0,18.

Teor de silte do solo 0,00 a 0,20 
ANEXO D- Regressões entre os atributos do solo na área 1
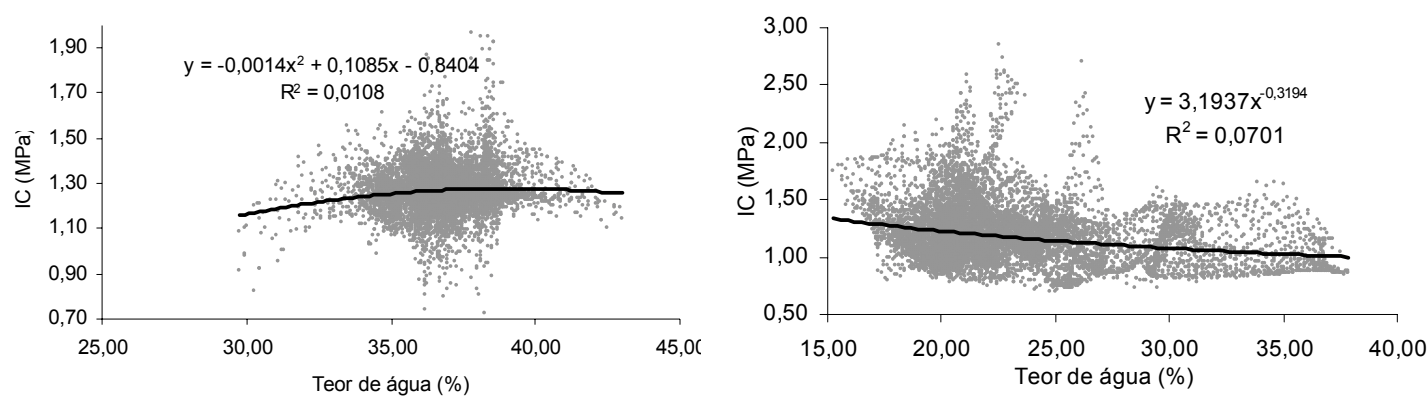

Teor de água e IC de 0,00 a 0,20 m

Teor de água e IC de 0,20 a 0,40 m
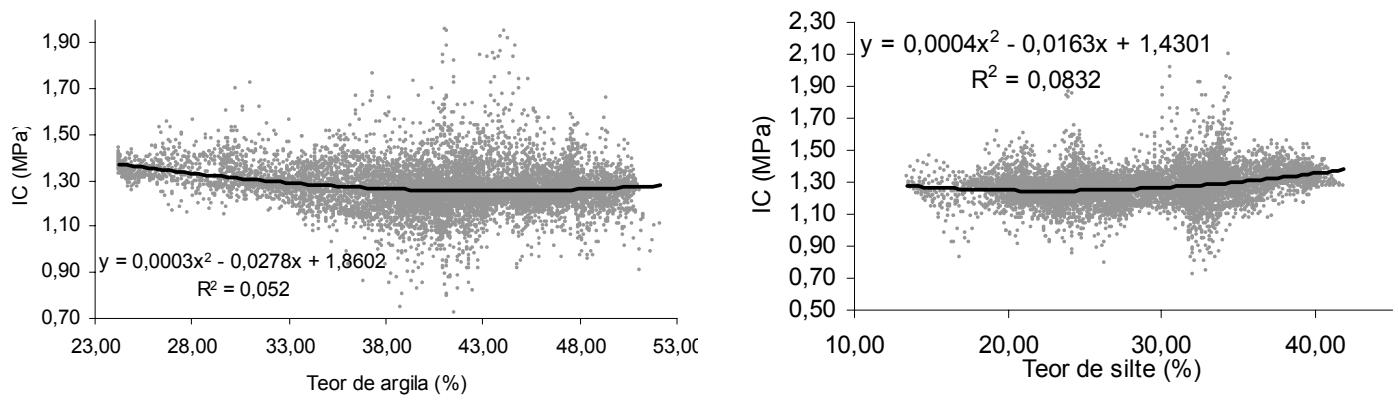

Teor de argila e IC de 0,00 a $0,20 \mathrm{~m}$

Teor de silte e IC de 0,00 a 0,20 m
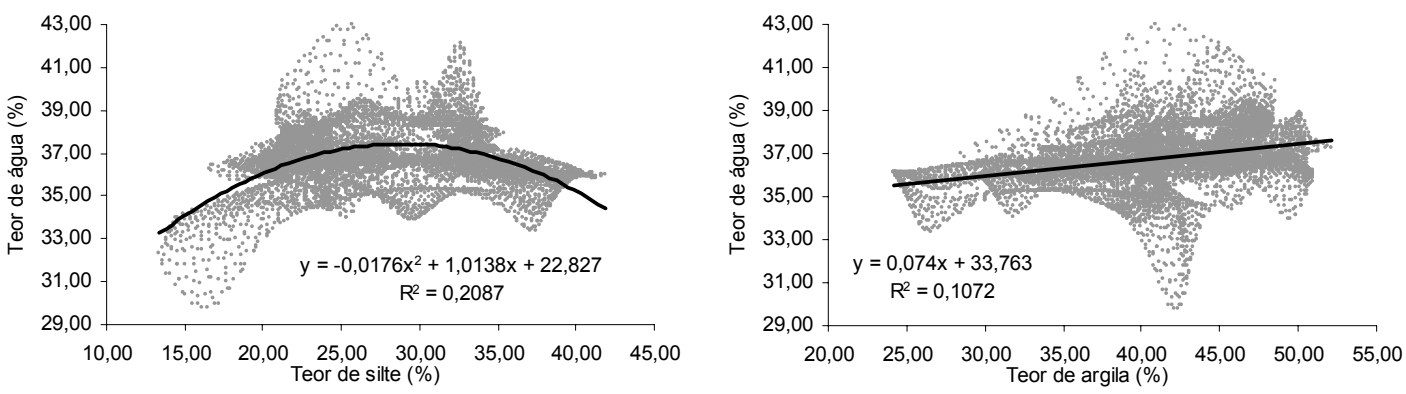

Teor de silte e teor de água de 0,00 a Teor de argila e teor de água de 0,00 $0,20 \mathrm{~m}$ a $0,20 \mathrm{~m}$ 
ANEXO E- Regressões entre os atributos do solo na área 2
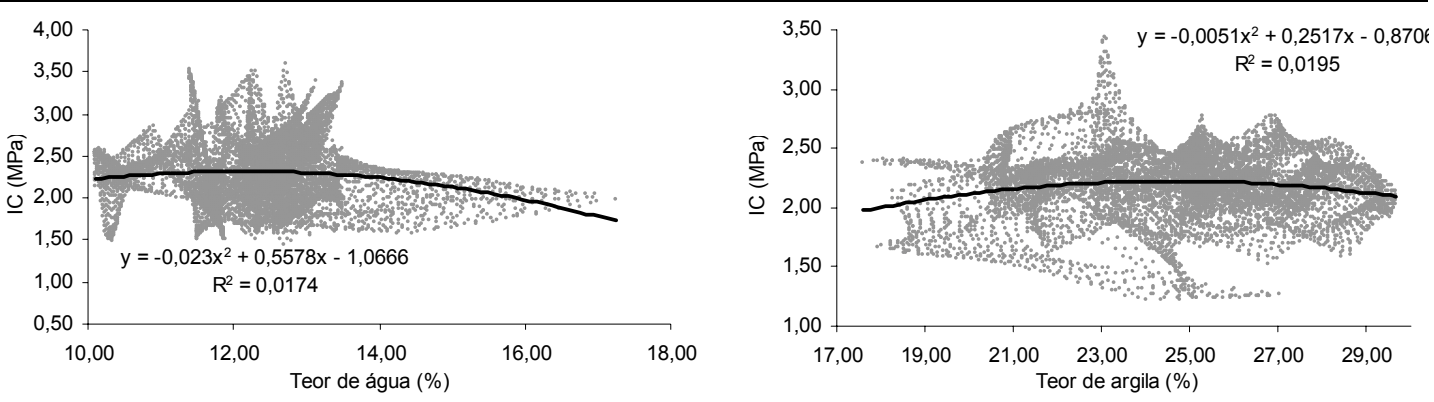

Teor de água e IC de 0,00 a 0,30 m

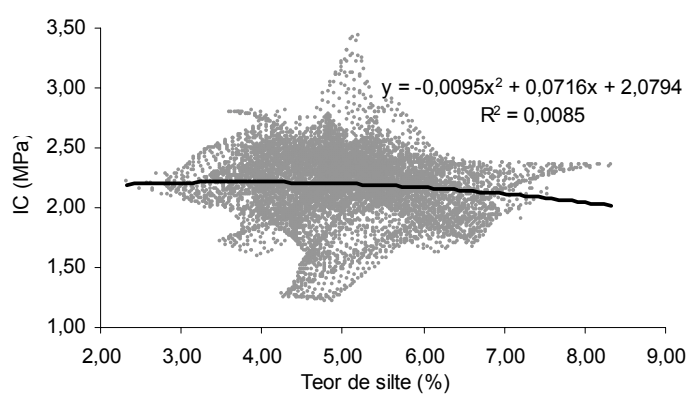

Teor de argila e IC de 0,00 a 0,40 m

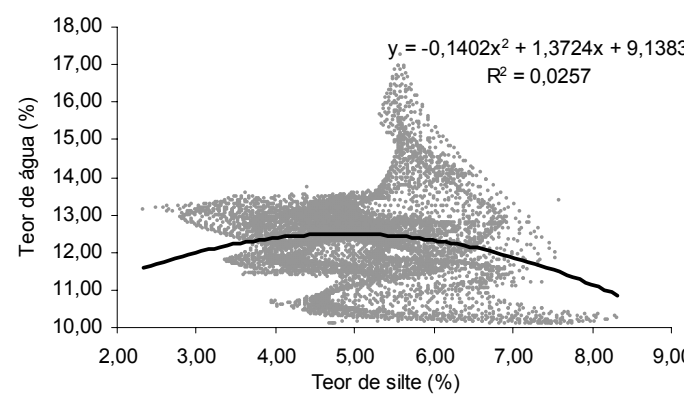

Teor de silte e IC de 0,00 a 0,40 m

Teor de silte de 0,00 a $0,40 \mathrm{~m}$ e teor de água de 0,00 a $0,30 \mathrm{~m}$

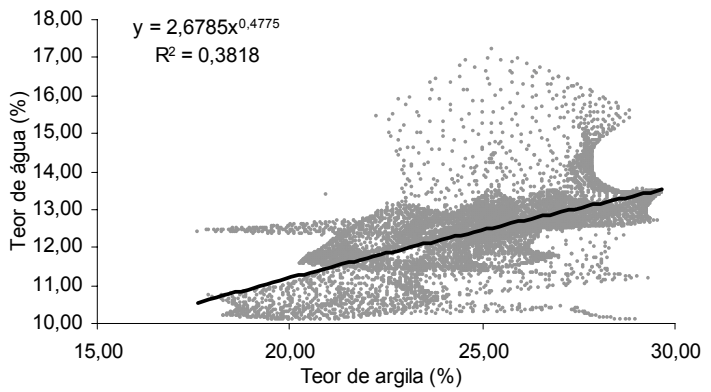

Teor de argila de 0,00 a $0,40 \mathrm{~m}$ e teor de água de 0,00 a $0,30 \mathrm{~m}$ 
ANEXO F- Regressões entre os atributos do solo na área 3.
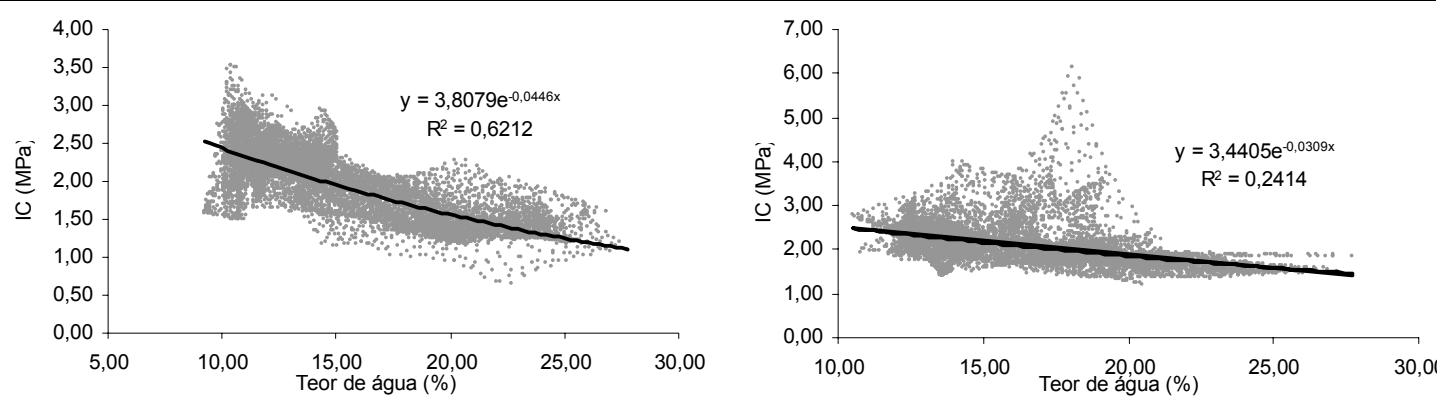

Teor de água e IC de 0,00 a 0,20 m

Teor de água e IC de 0,20 a 0,40 m
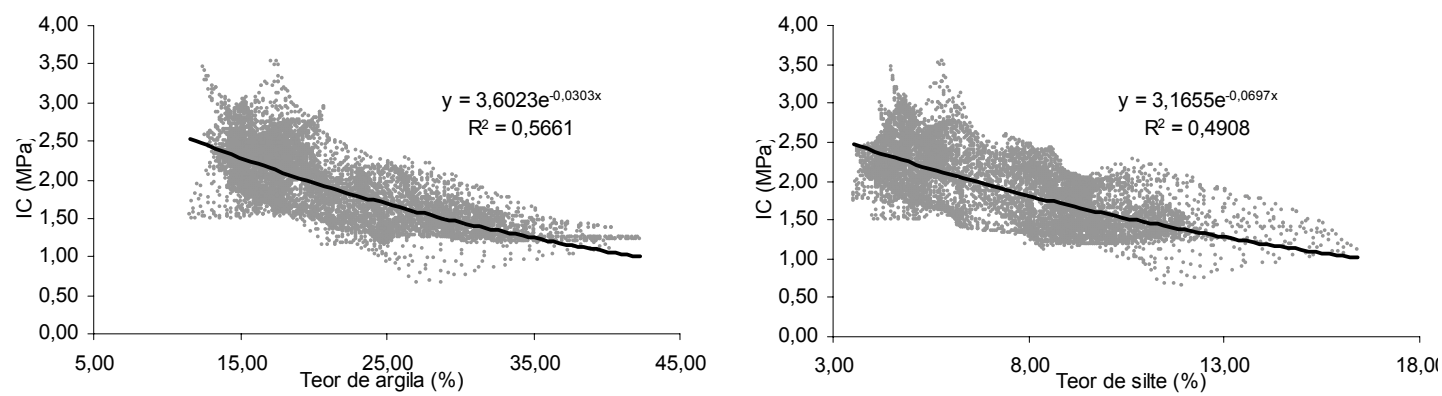

Teor de argila e IC de 0,00 a 0,20 m

Teor de silte e IC de 0,00 a 0,20 m
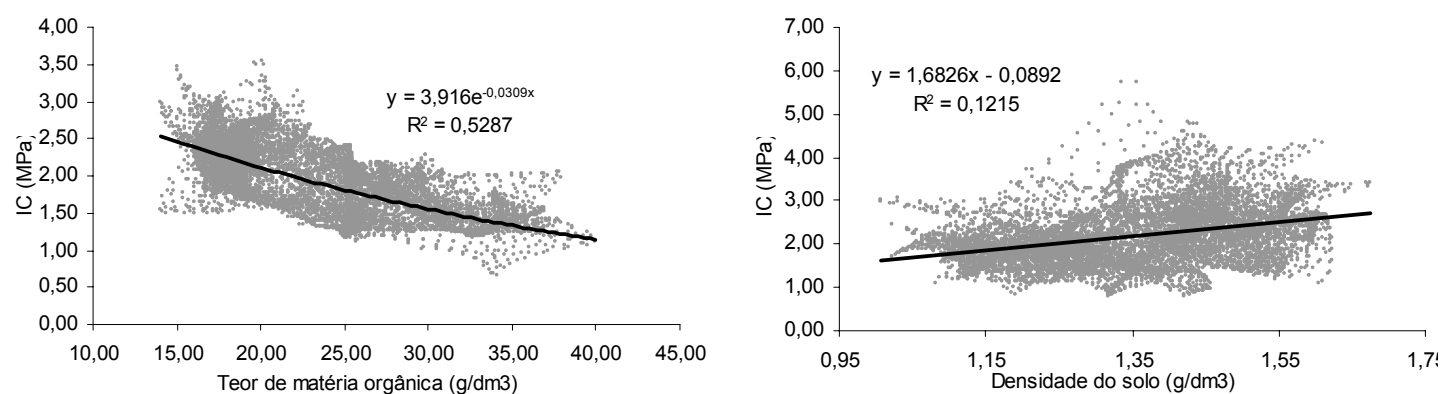

Teor de matéria orgânica e IC de 0,00 a $0,20 \mathrm{~m}$
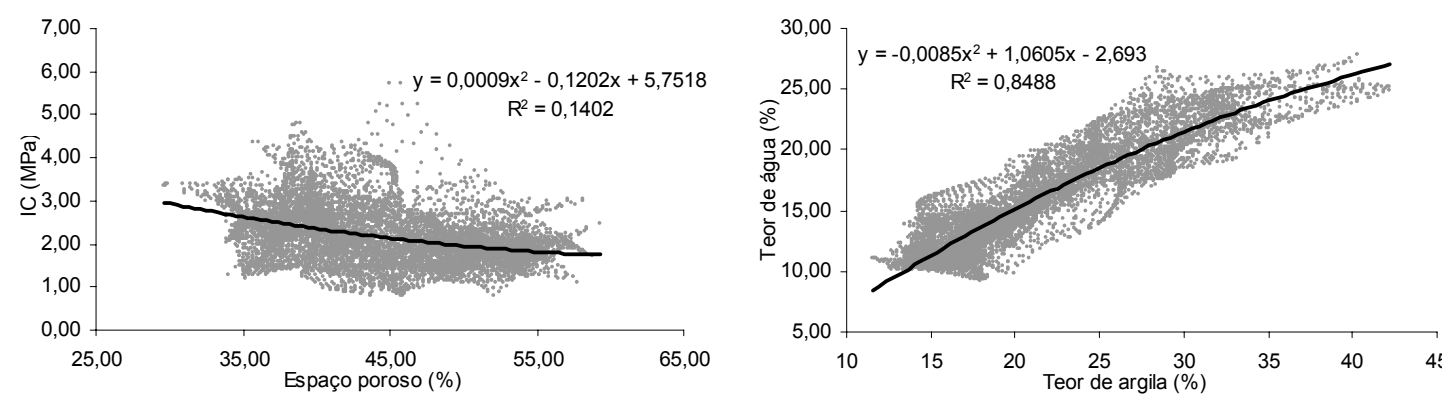

Espaço poroso e IC de 0,15 a 0,20 m. Teor de argila e teor de água de 0,00 a $0,20 \mathrm{~m}$ 
ANEXO F- Regressões entre os atributos da área 3.

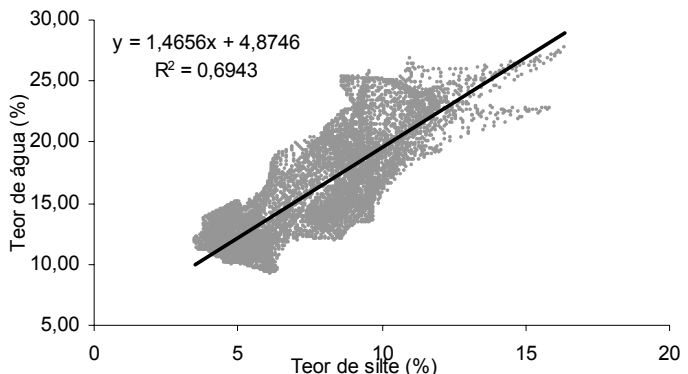

Teor de silte e teor de água de 0,00 a 0,20

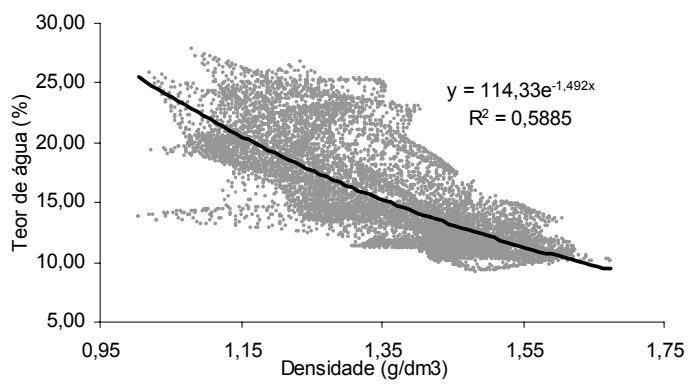

Densidade de 0,15 a $0,20 \mathrm{~m}$ e teor de água de 0,00 a $0,20 \mathrm{~m}$

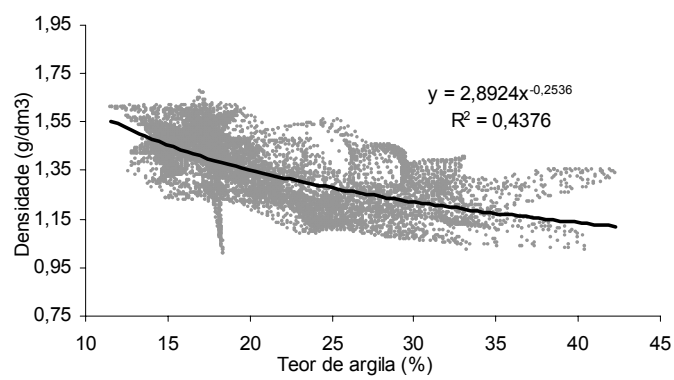

Teor de argila de 0,00 a 0,20 e densidade do solo de 0,15 a $0,20 \mathrm{~m}$

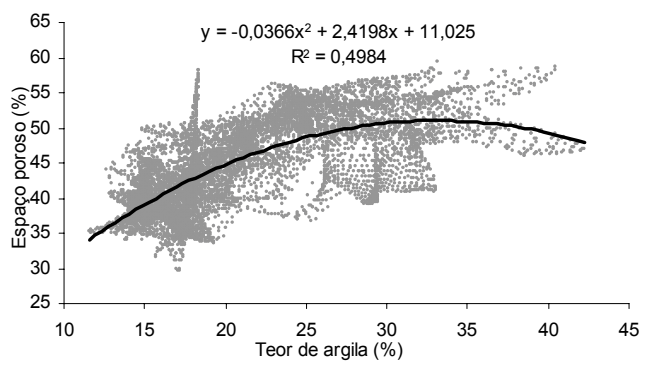

Teor de argila de 0,00 a $0,20 \mathrm{~m} \mathrm{e}$ espaço poroso de 0,15 a $0,20 \mathrm{~m}$

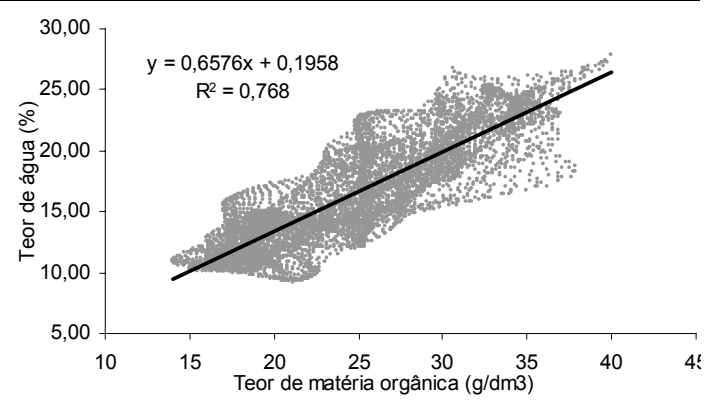

Teor de matéria orgânica e teor de água de 0,00 a $0,20 \mathrm{~m}$

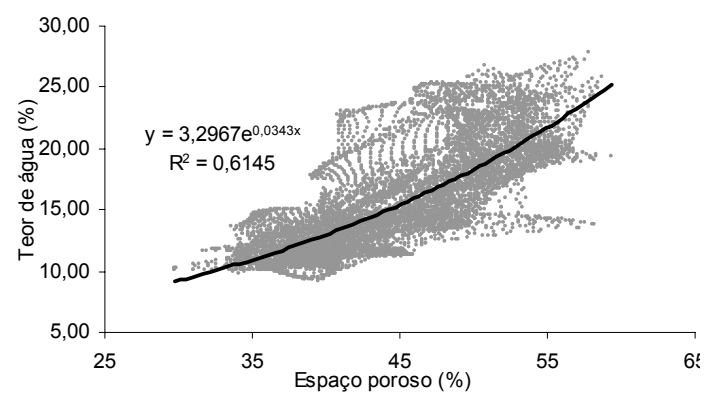

Espaço poroso de 0,15 a $0,20 \mathrm{~m}$ e teor de água de 0,00 a $0,20 \mathrm{~m}$

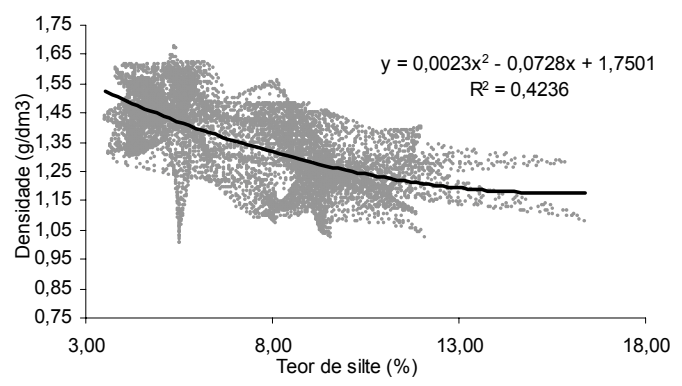

Teor de silte de 0,00 a 0,20 e densidade do solo de 0,15 a 0,20 m

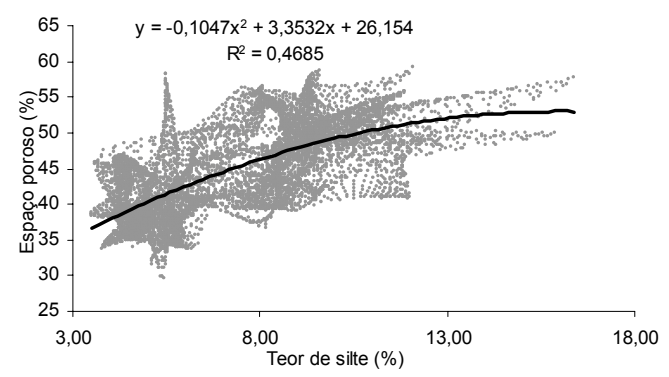

Teor de silte de 0,00 a $0,20 \mathrm{~m}$ e espaço poroso de 0,15 a $0,20 \mathrm{~m}$ 
ANEXO F- Regressões entre os atributos da área 3.
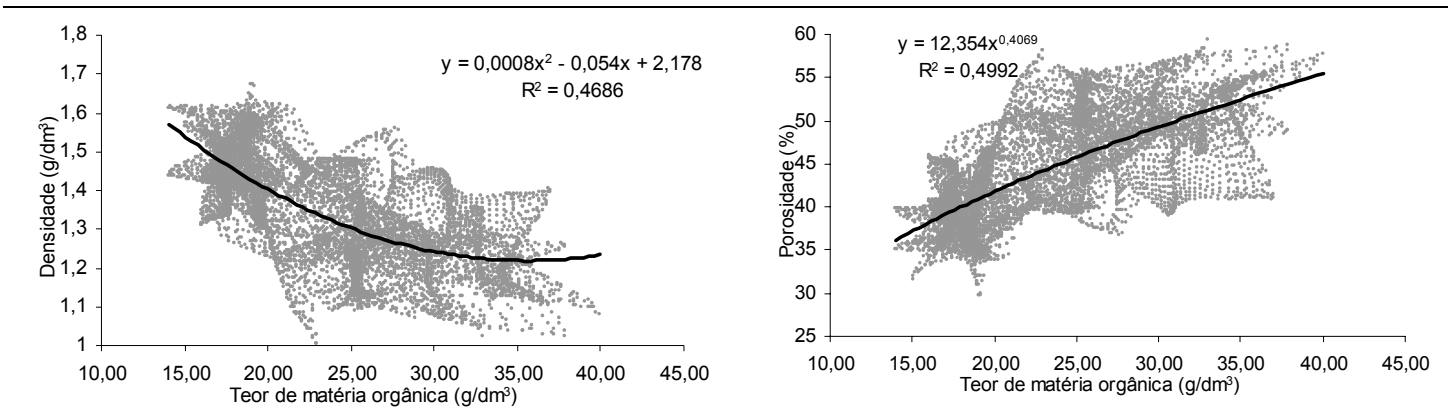

Teor de matéria orgânica de 0,00 a $0,20 \mathrm{~m}$ e densidade do solo de $0,15 \mathrm{a}$ $0,20 \mathrm{~m}$

Teor de matéria orgânica de 0,00 a $0,20 \mathrm{~m}$ e espaço poroso de $0,15 \mathrm{a}$ $0,20 \mathrm{~m}$
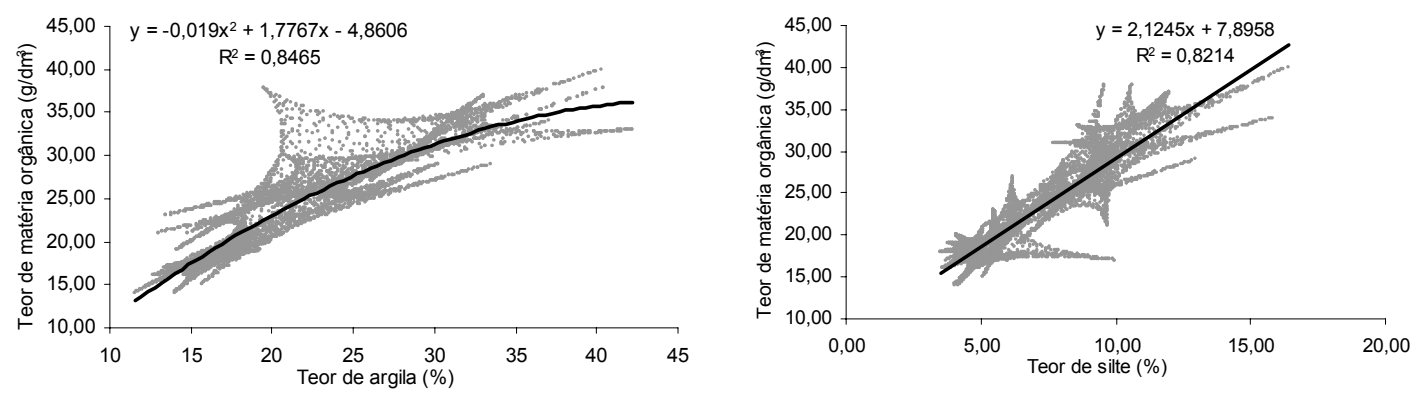

Teor de argila e teor de matéria orgânica de 0,00 a 0,20 m

Teor de silte e teor de matéria orgânica de 0,00 a 0,20 m

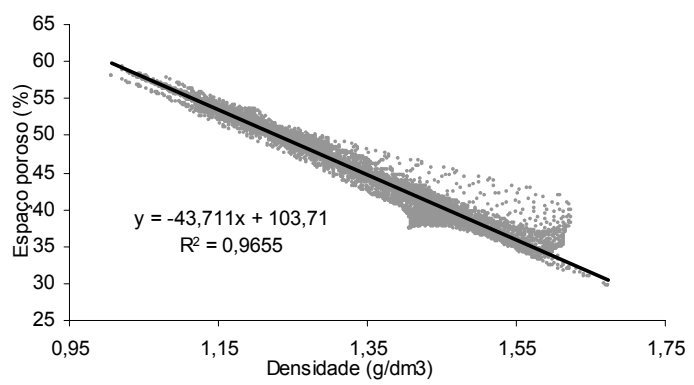

Densidade e espaço poroso do solo na profundidade de 0,15 a 0,20 m 


\section{REFERÊNCIAS BIBLIOGRÁFICAS}

AASE, J.K.; BJORNEBERG, D.L.; SOJKA, R.E. Zone-subsoiling relationships to bulk density and cone index on a furrow-irrigated soil. Transactions of The ASAE, v.44, n. 3, p. 577-583, 2001.

ABRÃO, P.U.R.; ELTZ, F.L.F.; G, M.; CASSOL, E.A.; GOEPFERT, C.F. Efeitos de diferentes sistemas de preparo do solo sobre as características físicas de um latossolo roxo distrófico. In: ENCONTRO NACIONAL DE PESQUISA SOBRE CONSERVAÇÃO DO SOLO, 2., Passo Fundo, 1978. Anais. Passo Fundo: EMBRAPA/CNPT, 1978. p. 405-413.

ADAMCHUK, V.I.; MORGAN, M.T.; SUMALI, H. Application of a strain gauge array to estimate soil mechanical impedance on-the-go. Transactions of the ASAE, v.44, n. 6, p. 1377-1383, 2001.

AMERICAN SOCIETY OF AGRICULTURAL ENGINEERS (ASAE). Procedures for using and reporting data obtained with the soil cone penetrometer- 46.ed. St. Joseph, MI. 1999. p.991-993. (ASAE Standard SEP 542).

ASSOULINE, S.; TAVARES, J.; TESSIER, D. Effect of compaction on soil physical and hydraulic properties: experimental results and modeling. Soil Science Society of America Journal, v.61,n.2,p.390-398, 1997.

BALESDENT, J.; CHENU, C.; BALABANE, M. Relationship of soil organic matter dynamics to physical protection and tillage, Soil Tillage Reassert, v.53, p. 215-230, 2000.

BAVER, L.D.; GARDNER, W.H.; GARDNER, W.R. Soil Physics. 4.ed. New York: John Wiley, 1979. 329p.

BERTOL, I.; BEUTLER, J.F.; LEITE, D.; BATISTELA, O. Propriedades físicas de um cambissolo húmico afetadas pelo tipo de manejo do solo. Scientia Agrícola, v.58, n.3, p. 555-560, jul/set 2001. 
BLAKE, G.R. Bulk density. In: BLAKE, C.A. (Ed.), Methods of soil analysis; physical and mineralogical properties, including statistics of measurement and sampling. Madison: American Society of Agronomy, 1965. p. $374-390$.

BLAKE, G.R.; HARTGE. K.H. Bulk density. In Klute, A. (Ed.). Methods of soil analysis. Part 1: Physical and mineralogical methods. 2 ed. Madison: SSSA. p. $363-375,1986$.

BLITZKOW, D. Aspectos gerais do sistema NAVSTAR/GPS. São Paulo: EPUSP, $1995.31 \mathrm{p}$.

BONSU, M. A physically based model for surface sealing of soil. Journal of Soil Science, v.43, p.229-235, 1992.

BORGES, E.N.; NOVAIS, R.F.; FERNANDEZ, B.; BARROS, N.F. Respostas de variedades de soja à compactação de camadas de solo. Revista Ceres, v.35, p.553-568, 1988.

BORGES, E.N.; NETO, F.L.; CORRÊA, G.F.; BORGES, E.V.S. Alterações físicas introduzidas por diferentes níveis de compactação em latossolo vermelho-escuro textura média. Pesquisa Agropecuária Brasileira, v.34, n.9, p.1663-1667, set. 1999.

BRADY, C.B.; WEIL, R.R. The nature and properties of soils. 3.ed. New York: Prentice Hall, 2001. 960p.

BRAGA, L.P.V. Geoestatística e aplicações. Rio de Janeiro: Departamento de Métodos Estatísticos do Instituto de Matemática da Universidade Federal do Rio de Janeiro, 1990. 36p.

BRUCE, J.P.; FROME, M.; HAITES, E.; JANZEN, H.; LAL, R. Carbon sequestration in soils. Journal of Soil and Water Conservation, v.54, p.382-389, 1999.

BURROUGH, P.A. Principles of geographical information systems: methods and requirements for land use planning. Oxford: Clarendon Press, 1986. 194p.

CAMBARDELLA, C.A.; MOORMAN, T.B.; NOVAK, J.M.; PARKIN, T.B.; KARLEN, D.L.; TURCO, R.F.; KONOPKA, A.E. Field- scale variability of soil properties in central lowa soils. Soil Science Society of America Journal. v.58, n.5. p. 1501-1511, 1994. 
CORREAA, J,C. Efeito de sistemas de cultivo na estabilidade de agregados de um latossolo vermelho-amarelo em querência, MT. Pesquisa Agropecuária Brasileira, v.37, n. 2, p.203-209, fev. 2002.

CARTER, L.M. Portable recording penetrometer measures soil strength profiles. Agricultural Engineering, v.48, n.6, p. 348-349, 1967.

CARTER, L.M. Integrating penetrometer provides average soil strength. Agricultural Engineering, v. 50, n. 10, p.618-619, Oct. 1969.

DIAS JUNIOR, M.de.S.; PIERCE, F.J. O processo de compactação do solo e sua modelagem. Revista Brasileira de Ciência do Solo, v. 20, p.175-182, 1996.

DUXBURY, J.M.; SMITH, M.S.; DORAN, J.W. Soil organic matter as a source and sink of plant nutrients. In: COLEMAN, D.C.; OADES, J.M.; UEHARA, G. (Ed.) Dynamics of soil organic matter in tropical ecosystems. Honolulu: University of Hawaii Press, NIFTAL project, 1989. p.33-67.

ELLIOT, E.T. Aggregate structure and carbon, nitrogen and phosphorus in native and cultivatede soils. Soil Science Society of America Journal, v.50, p.627-633, 1986.

EMPRESA BRASILEIRA DE PESQUISA AGROPECUÁRIA. Manual de métodos de análise de solo. 2.ed. Rio de Janeiro: Centro Nacional de Pesquisa de Solos, 1997. 212p.

ETANA, A.; COMIA, R.A.; HADANSSON, I. Effects of uniaxial stress on the physical properties of four Swedish soils. Soil and Tillage Reserarch, v.44, n.1, p.13-21, 1997.

FARIA, R.T.de.; CARAMORI, P.H. Caracterização físico-hídrica de um latossolo roxo distrófico do município de londrina, PR. Pesquisa Agropecuária Brasileira, v.21, p.1303-1311, jun. 1986.

FOLEGATTI, M.V.; SILVA, A.P.da.; DE MARIA, I.C. Avaliação da resistência do solo à penetração utilizando penetrômetro e penetrógrafo. In: CONGRESSO BRASILEIRO DE ENGENHARIA AGRÍCOLA, 19., Piracicaba, 1990. Anais. Piracicaba: SBEA/ESALQ, 1990. p.525-541.

GAVANDE, S.A. Física de suelos: princípios e aplicaciones. México: Limusa Wiley, 1972. 351p. 
GEE, G.W.; BAUDER, J.W. Particle-size analysis. In: KLUTE, A., ed. Methods of soil analysis. Part 1. Physical and mineralogical methods. 2.ed. Madison, American Society of Agronomy, Soil Science Society of America, 1986. p.383-411. (Agronomy Series, 9).

GUIAMARÃES, C.M.; MOREIRA, J.A.A. Compactação do solo na cultura do arroz de terras altas. Pesquisa Agropecuária Brasileira, v. 36, n. 4, p.703707, Abr. 2001.

GUPTA, S.C.; ALLMARAS, R.R. Models to acces The susceptibility of soil to excessive compaction. Soil Science, v.6, p.65-100, 1987.

HAKANSSON, I.; VOORHEES, W.B.; RILEY, H. Vehicle and wheel factors influencing soil compaction and crop response in different traffic regimes. Soil and Tillage Research, v.11, n.3, p.239-282, 1988.

HENDERSON, C.; LEVETT, A.; LISLE,D. The effects of soil water content and bulk density on the compactibility of some western Australina sandy soils. Australian Journal of Soil Resesrch v. 26, p. 391-400, 1988.

HERRICK, J.E.; JONES, T.L. A dynamic cone penetrometer for measuring soil penetration resistance. Soil Science Society of America Journal, v.66, n.4, p.1320-1324, 2002.

IMHOFF, S.; SILVA, A.P.da.; TORMENA, C.A. Aplicações da curva de resistência no controle da qualidade física de um solo sob pastagem, Pesquisa Agropecuária Brasileira, v.35, n.7, p.1493-1500, jul. 2000.

JACKSON, M.L. Analisis químico de suelos. Barcelona: Omega, 1982. 662 p.

KLEIN, V.A. Propriedades físico-hídrico-mecânicas de um latossolo roxo, sob diferentes sistemas de uso e manejo. Piracicaba, 1998. 150p. Tese (Doutorado)- Escola Superior de Agricultura "Luiz de Queiroz", Universidade de São Paulo.

LANÇAS, K.P.; NETO, P.C.; NAGAOKA, A.K.; GUERRA, S.P.S. Índice de cone e mapas de isocompactação do solo agrícola, obtidos com a utilização de um penetrômetro hidráulico-eletrônico e um sistema de posicionamento global diferencial (DGPS). In: Balastreire, L.A. O estado-da-arte da agricultura de precisão no Brasil. Piracicaba: o autor, 2000, p.113-123.

LARSON, W.E.; GUPTA, S.C.; USECHE, R.A. Compression of agricultural soil from eight soil orders. Soil Science Society of America Journal, v.44, n.3, p.450-457, 1980. 
MACBRATNEY, A.B.; WEBSTER, R. Haw many observations are needed for regional estimation of soil properties? Soil Science, v 135, n.3. p.177- 183, 1983.

MACHADO, J.A.; BRUM, A.C.R. Efeito dos sistemas de cultivo reduzido e convencional na capacidade de infiltração da água no solo. In: ENCONTRO NACIONAL DE PESQUISA SOBRE CONSERVAÇÃO DO SOLO, 2, Passo Fundo, 1978. Anais. Passo Fundo: EMBRAPA/CNPT, 1978. p. 331-339.

MACKIE-DANWSON, L.A.; MULLINS, C.E.; KIRKLAND, J.A.; FITZPATRICK, E.A. The determination of the macroporosity of impregnated blocks of a clay soil and its relation to volumetric water content. Journal of Soil Science, v. 39, p. $65-70,1988$.

MCBRIDE, R.A. Estimation of density-moisture-stress functions from uniaxial compression of unsaturated, structured soils. Soil and Tillage Research, v.13, n.4, p.383-397, 1989.

MIELNICKUK, J. Modificações da estrutura do solo. In: CONGRESSO BRASILEIRO DE CIÊNCIA DO SOLO, 24., Goiânia, 1993. Resumos. Goiânia: Sociedade Brasileira de Ciência do Solo, 1993. p.21-22.

MINASNY, B.; MCBRATNEY, A.B. Fuz ME version 2.1. Australian Center for Precision Agriculture, The University of Sydney. 2002. http://www.usyd.edu.au/su/agri/acpa. (23. Feb.2002)

MOLIN, J.P. Agricultura de precisão: $O$ gerenciamento da variabilidade. Piracicaba: o autor, 2001. 83p.

MOLIN, J.P.; COUTO, H.T.Z; GIMENEZ, L.M.; PAULETTI, V.; MOLIN, R.; VIEIRA, S.R. Regression and correlation analysis of grid soil data versus cell spatial data. ECPA, n.3, p.449-453, 2001.

MORAES, M.H. Efeitos da compactação em algumas propriedades físicas do solo e no desenvolvimento do sistema radicular de plantas de soja (glycine Max (L.) MERRILL). Piracicaba, 1988. 114p. Dissertação (Mestrado)- Escola Superior de Agricultura "Luiz de Queiroz", Universidade de São Paulo.

MORAES, M.H.; VILLAS BÔAS, R.L.; BREDA, C.C.; ELIAS JUNIOR, R.C.; VERGAMINI LUNA, P.E.; PRADO FILHO, R.S. Desenvolvimento e estado nutricional de plantas de feijão como decorrência da compactação subsuperficial do solo. In: CONGRESSO BRASILEIRO DE ENGENHARIA AGRíCOLA, 27., Poços de Caldas, 1998. Anais. Poços de Caldas: SBEA, 1998. p.70-72. 
NEWMAN, S,C,; HUMMEL, J,W. Soil pentration resistance with moisture correction, St.Joseph: ASAE, 1999, 21p.

NEWTON, K.; DROVER, D.P. The influence of various rotations on corse textured soils at chapman and wogan hills research stations, Western Australia. II. Some physical characteristics of soils. Journal of Soil Science, v.7, n.2, p.226-234, Sep. 1956.

NOVAK, L.R.; MANTOVANI, E.C.; MARTYN, P.J.; FERNANDES, B. Efeito do tráfego de trator e da pressão de contato pneu/solo na compactação de um latossolo vermelho-escuro álico em dois níveis de umidade. Pesquisa Agropecuária Brasileira, v.27, n.12, p.1587-1595, dez. 1992.

OLIVEIRA, P.M.de.; SALVADOR, N.; LIMA, L.A.; LEDO, C.A.S. Efeitos de sistemas de preparo periódico do solo na capacidade de campo de um latosolo vermelho escuro sob cerrado, durante as fases fenológicas da cultura do milho. In: CONGRESSO BRASILEIRO DE ENGENHARIA AGRíCOLA, 27., Poços de Caldas, 1998. Anais. Poços de Caldas: SBEA, 1998. p.184-186.

PONTES, J.M. A geoestatística: aplicações em experimentos de campo. Lavras, 2002. 82p. Dissertação (Mestrado)- Universidade Federal de Lavras.

POWLSON, D.S.; BROOKES, P.C.; CHRISTENSEN, B.T. Measurament of soil microbial biomass provides an early indication of changes in total soil organic matter due to straw incorporation. Soil Biology \& Biochemistry, v.19, p.159-164, 1987.

RAIJ, B.V; de ANDRADE, J.C; CANTARELLA, H; QUAGGIO, J.A. Análise química para avaliação da fertilidade de solos tropicais, Campinas: Instituto Agronômico, 2001. 285 p.

REICHERT, J.M.; VEIGA, M. da.; CABEDA, M.S.V. Índices de estabilidade de agregados e suas relações com características e parâmetros de solo. Campinas. Revista Brasileira de Ciência do Solo, v.17, n.2, p.283-290, mai/ago. 1993.

SANTOS, J.C.F. Comportamento de propriedades físicas e químicas de dois latossolos roxos sob diferentes sistemas de rotação de culturas em plantio direto. Lavras, 1993. 101p. Dissertação (Mestrado)- Escola Superior de Agricultura de Lavras.

SATURNINO, H.M.; LANDERS, J.N. O meio ambiente e o plantio direto. Brasília: Embrapa/SPI, 1997. 116p. 
SEIXAS, F. Compactação do solo devido à mecanização florestal: causas, efeitos e práticas de controle. Circular técnica. IPEF, n.163, p.1-10, 1988.

SEIXAS, F.; JUNIOR, E,D,O. Compactação do solo devido ao tráfego de máquinas de colheita de madeira, Scientia Florestalis, n.60, p.78-87, dez.2001.

SÉGUY, L.; BOUZINAC, S. Direct seeding on plant covers: sustainable cultivation of our planet's soils. In: GARCIA TORRES L., BENITES J. MARTÍNEZ VILELA A. Conservation Agriculture, a worldwide challenge, (Ed.). In: WORLD CONGRESS ON CONSERVATION AGRICULTURE, Proceedings, Madrid: s. ed., 2001. p. 85-91.

SHAPIRO, S.S., WILK, M.B. Na analysis of variance test for normality. Biometrika, v.52, p.591-611, 1965.

SHIRATSUCHI, L.S. Mapeamento da variabilidade espacial das plantas daninhas com a utilização de ferramentas da agricultura de precisão. Piracicaba, 2001. 96p. Dissertação (Mestrado)- Escola Superior de Agricultura "Luiz de Queiroz", Universidade de São Paulo.

SILVA, A.P. Influência da compactação nas propriedades físicas do solo e no sistema radicular de plântulas de algodão (Gossypium hirsutum, L.). Piracicaba, 1984. 75p. Dissertação (Mestrado)- Escola Superior de Agricultura "Luiz de Queiroz", Universidade de São Paulo.

SILVA JUNIOR, R.L.da. Variabilidade espacial do índice de cone correlacionada com mapas de produtividade. Piracicaba, 2001. 132p. Dissertação (Mestrado)- Escola Superior de Agricultura "Luiz de Queiroz", Universidade de São Paulo.

SILVA, R. B. da. Compressibilidade e resistência ao cisalhamento de um latossolo sob diferentes intensidades de uso na região dos cerrados. Lavras, 2002. 142p. Dissertação (Doutorado)- Universidade Federal de Lavras.

SIX, J.; FELLER, C.; DENEF, K.; OGLE, S, M. Soil organic matter, biota and aggregation in temperate and tropical soils - Effectes of no-tillage, EDP Sciences, p. 755-775, mai. 2002.

TAYLOR, H.M.; GARDNER, H.R. Penetration of cotton seedling taprots as influenced by bulk density, moisture content, and strength of soil. Soil Science, v.96, n. 3, p.153-156, Sep. 1963. 
TEIXEIRA, W.; TOLEDO, M.C.M.; FAIRCHILD, T.R.; TAIOLI, F. Decifrando a terra: São Paulo: Oficina de textos, 2000. 558p.

TERRY, C.W.; WILSON, H.M. The Cornell soil penetrometer. Agricultural Engineering, v. 33, n.7, p. 425, July 1952.

TISDALL, J.M.; OADES, J.M. Organic matter and water-stable aggregates in soils. London. Journal of Soil Science, v.33, n.2, p.141-163, June 1982.

TRIPLETT JUNIOR, G.B.; VAN DOREN JUNIOR, .D.M, Nitrogen, phosphorus and potassium fertilization of non-tilled maize. Agronomy Journal, n. 61, p. 637-639, 1969.

URCHEI, M.A.; RODRIGUES, J.D.; STONE, L.F. Análise de crescimento de duas cultivares de feijoeiro sob irrigação, em plantio direto e preparo convencional. Pesquisa Agropecuária Brasileira, v.35, n.3, p.497-506, Mar. 2000.

VASQUES, L.; MYHRE, D.L.; HANLON, E.A.; GALLAHER. R.N.; Soil penetrometer resistance and bulk density relationships after long term no tillage. Commun. Plant Anal, n 22, p. 2101-2117, 1991.

VAZ, C.M.P.; HOPMANS, W.J. Simultaneous measurement of soil penetration resistance and water contet with a combined penetrometer - TDR Moisture Probe, Soil Sci. Soc. Am. J. nº 65, p.4-12, 2001.

ZAMBUZI, P.C.; BELLIN, M.P.; MOLIN, J.P. Penetrômetro para se medir resistência do solo à penetração. In: CONGRESSO NACIONAL DE ESTUDANTES DE ENGENHARIA MECÂNICA, 5., Espírito Santo, 1998. Resumos. Espírito Santo: UFES. 1998. 1v. 